\title{
LANDSCAPE STRUCTURE AFFECTS DIFFERENT EASTERN ONTARIO ANURAN SPECIES
}

\section{AT DIFFERENT SPATIAL SCALES}

\author{
By \\ Amanda F. Dam

\begin{abstract}
A thesis submitted to
the Faculty of Graduate Studies and Research

in partial fulfillment of

the requirements for the degree of

Masters of Science
\end{abstract}

Department of Biology

Carleton University

Ottawa, Ontario

September 2005

(C) 2005, Amanda F. Dam 


$\begin{array}{ll}\begin{array}{l}\text { Library and } \\ \text { Archives Canada }\end{array} & \begin{array}{l}\text { Bibliothèque et } \\ \text { Archives Canada }\end{array} \\ \begin{array}{l}\text { Published Heritage } \\ \text { Branch }\end{array} & \begin{array}{l}\text { Direction du } \\ \text { Patrimoine de l'édition }\end{array} \\ \begin{array}{l}\text { 395 Wellington Street } \\ \text { Ottawa ON K1A ON4 }\end{array} & \begin{array}{l}\text { 395, rue Wellington } \\ \text { Ottawa ON K1A ON4 } \\ \text { Canada }\end{array}\end{array}$

Your file Votre référence

ISBN: 0-494-10134-2

Ourfile Notre référence

ISBN: 0-494-10134-2

NOTICE:

The author has granted a nonexclusive license allowing Library and Archives Canada to reproduce, publish, archive, preserve, conserve, communicate to the public by telecommunication or on the Internet, loan, distribute and sell theses worldwide, for commercial or noncommercial purposes, in microform, paper, electronic and/or any other formats.

The author retains copyright ownership and moral rights in this thesis. Neither the thesis nor substantial extracts from it may be printed or otherwise reproduced without the author's permission.
AVIS:

L'auteur a accordé une licence non exclusive permettant à la Bibliothèque et Archives Canada de reproduire, publier, archiver, sauvegarder, conserver, transmettre au public par télécommunication ou par l'Internet, prêter, distribuer et vendre des thèses partout dans le monde, à des fins commerciales ou autres, sur support microforme, papier, électronique et/ou autres formats.

L'auteur conserve la propriété du droit d'auteur et des droits moraux qui protège cette thèse. $\mathrm{Ni}$ la thèse ni des extraits substantiels de celle-ci ne doivent être imprimés ou autrement reproduits sans son autorisation.
In compliance with the Canadian

Privacy Act some supporting forms may have been removed from this thesis.

While these forms may be included in the document page count, their removal does not represent any loss of content from the thesis.
Conformément à la loi canadienne sur la protection de la vie privée, quelques formulaires secondaires ont été enlevés de cette thèse.

Bien que ces formulaires aient inclus dans la pagination, il n'y aura aucun contenu manquant.

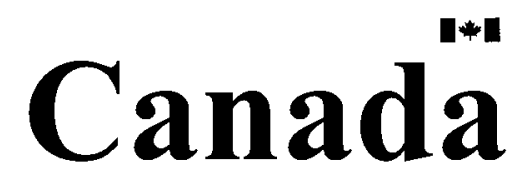




\section{AbSTRACT}

Many species of anurans (frogs and toads) are experiencing declines in

abundance. Research suggests that landscape alteration, particularly the loss of forest and the insertion of roads in landscapes, are important factors contributing to these declines. The purpose of this study was to answer the following questions: 1) Are abundances of different species of anurans in eastern Ontario most strongly affected by landscape structure at different spatial scales?, 2) Does the scale at which each species responds most strongly to landscape structure reflect its dispersal distance?, 3) Does each species respond most strongly at different scales to different landscape features (forest cover and paved road density)?, and 4) If yes, is the scale of strongest response to percent forest cover or paved road density a better indicator of species dispersal distance? These questions were addressed by measuring population abundance of seven anuran species endemic to eastern Ontario at 34 breeding ponds surrounded by landscapes of varying forest cover and road density. I found that different species were most strongly affected by landscape structure at different scales, ranging from $500 \mathrm{~m}$ to $2000 \mathrm{~m}$ from the breeding ponds. I also found that some species, such as the American Toad, Spring Peeper, and Western Chorus Frog responded at a larger scale to forest cover (500 m. $1500 \mathrm{~m}$ and $2000 \mathrm{~m}$, respectively) than paved road density $(250 \mathrm{~m}, 150 \mathrm{~m}$, and $150 \mathrm{~m}$, respectively). There was a positive correlation between dispersal distance and the scale of response to landscape structure. My results suggest that the current approach to wetland conservation, of imposing $120 \mathrm{~m}$ no-development buffers around wetlands, will not protect anuran diversity. The buffer system needs to be augmented with regional land management policies and programs. 


\section{ACKNOWLEDGEMENTS}

First of all, I would like to thank the members of the Geomatic and Landscape Ecology Research Laboratory for providing me a wonderful academic environment to study in the last two years. It was a wonderful working environment to be apart of and I thank all the members for their friendship, support and advice, for being there during the laughter and the tears, and especially for their willingness to help me procrastinate. To R. Bemrose, D. Bert, J. Brennan, N. Charbonneau, S. Duguay, F. Eigenbrod, L. Fahrig, A. Ford, S. Gagne, M. Harvey, K. Henein, J. Jaeger, M. Larivée, M. Lindsay, R. McGregor, L. Olsen, D. Omond, J. Pasher, K. Ryall, T. Rytwinski, A. Smith, J. Tews, R. Tittlermany thanks.

To Dr. L. Fahrig, my supervisor, I would like to thank her for providing me with the opportunity to study my Masters and for all her guidance and instruction. I have learned so much these past few years and I thank you for helping me through my academic journey. I would also like to thank Dr. K. Lindsay and Dr. J. Kerr for being my advisors. Your helpful advice has been critical in making my research the best it could be. Thank you for looking at my work with fresh eyes and new insights.

I would also like to thank everyone who helped collect the data used for this study and to all the landowners who allowed me use of their ponds. Without their help this research would not have been possible. I hope it was as educational an experience for them as it was for me. I would especially like to thank S. Gagne who shared the workload, stress, and fieldwork experience with me and N. Chepelev, Q. Khan and F. Eigenbrod who I could always count on to go "frogging". 
This work was supported financially by the Natural Sciences and Engineering Research Council of Canada and Carleton University. Thank you for the assistance.

Finally, I would like to dedicate this thesis to my parents, Inge and Jorgen Dam, and to my sister and brother-in-law, Rikke and Keith Brown. Thank you for you love, support and constant encouragement. 


\section{TABLE OF CONTENTS}

ABSTRACT .........................................................................................................................II

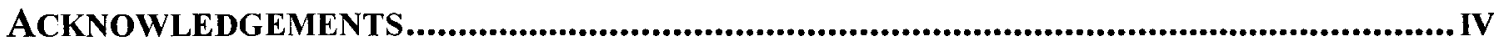

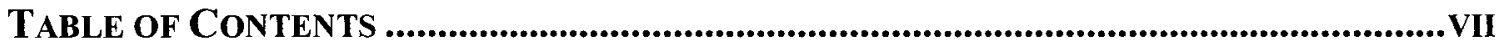

LIST OF TABLES ........................................................................................................... VIII

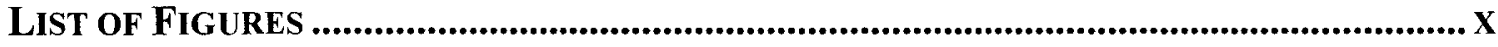

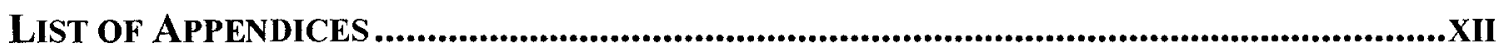

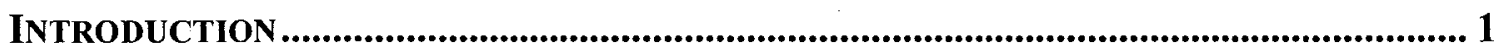

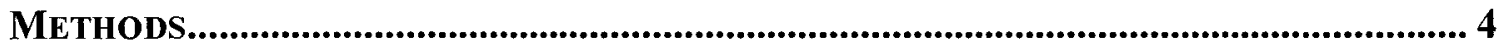

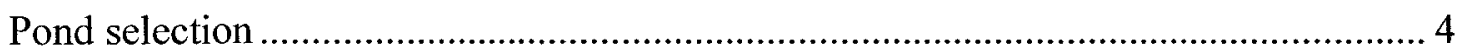

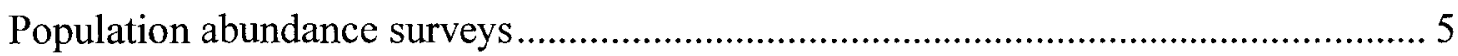

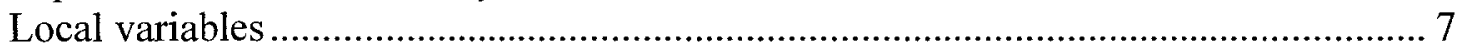

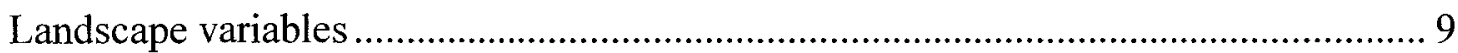

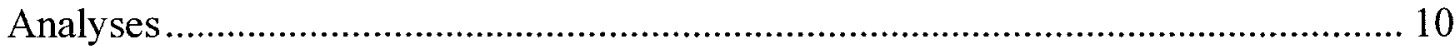

1. Are abundances of different species of anurans in eastern Ontario most strongly affected by landscape structure at different scales? ......................................... 10

2. Does the scale at which each species responds most strongly to landscape structure reflect its dispersal distance? ........................................................... 11

3. Does each species respond most strongly at different scales to different landscape features (forest cover and paved road density)? ............................................... 12

4. If yes, is the scale of strongest response to percent forest cover or paved road density a better indicator of species dispersal distance? .................................. 13

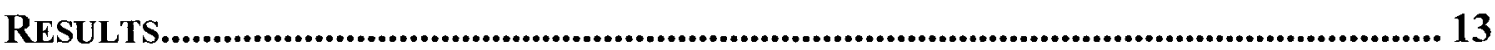

1. Are abundances of different species of anurans in eastern Ontario most strongly affected by landscape structure most strongly at different scales?

2. Does the scale at which each species responds most strongly to landscape structure reflect its dispersal distance? ............................................................................ 14

3. Does each species respond most strongly at different scales to different landscape features (forest cover and paved road density)? ................................................ 14

4. If yes, is the scale of strongest response to percent forest cover or paved road density a better indicator of species dispersal distance? 


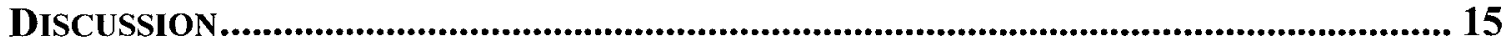

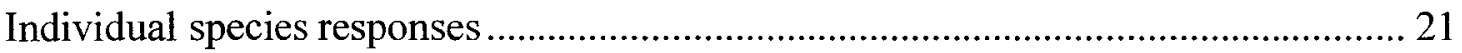

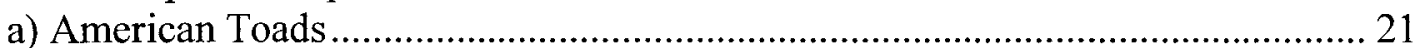

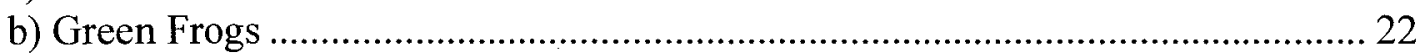

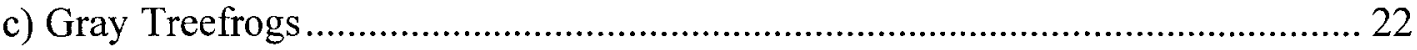

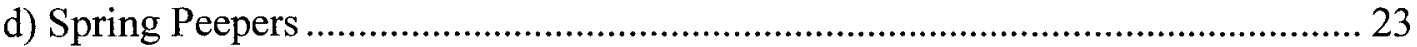

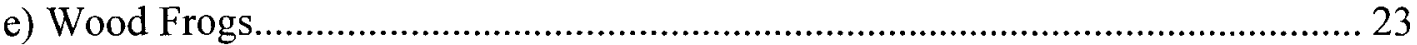

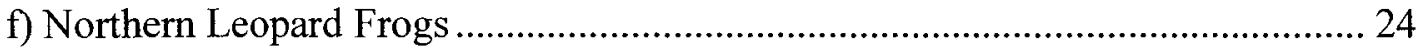

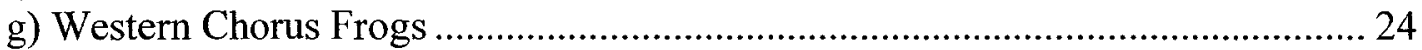

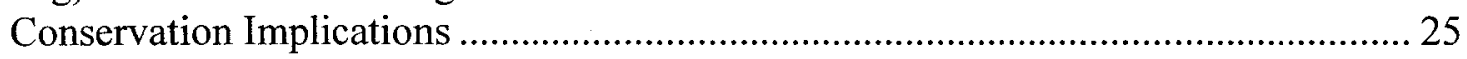

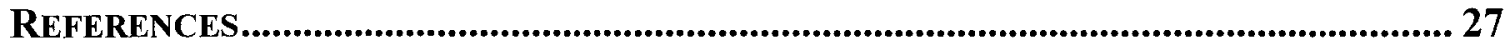




\section{LIST OF TABLES}

Table 1. Variation in percent forest cover quantified within $150 \mathrm{~m}$, and $250 \mathrm{~m}$ to $2000 \mathrm{~m}$ radii buffers (at $250 \mathrm{~m}$ intervals) around the study ponds using digitized 1:50,000 National Topographic Data Base (1985-1995) maps. See Appendix A for values for each pond.

Table 2. Variation in paved road density quantified within $150 \mathrm{~m}$, and $250 \mathrm{~m}$ to $2000 \mathrm{~m}$ radii buffers (at $250 \mathrm{~m}$ intervals) around the study ponds using digitized 1: 50,000 National Road Network, Canada, Level 1 (2002) maps. See Appendix A for values for each pond.

Table 3. Pearson correlations between percent forest cover and paved road density $\left(\mathrm{m} / \mathrm{km}^{2}\right)$ at $150 \mathrm{~m}$, and $250 \mathrm{~m}$ to $2000 \mathrm{~m}$ radii buffers (at $250 \mathrm{~m}$ intervals) around the study ponds $(\mathrm{n}=34)$.

Table 4. $\mathrm{X}^{2}$ values associated with the effect of landscape structure (forest cover (F) plus paved road density (R)) from separate models at each scale for each species using multiple multinomial logistic regression analyses. Other variables included in the models were average pond $\mathrm{pH}$, pond perimeter, and percent vegetation cover of shore plants. Bolded values indicate the spatial scale at which the relationship was the strongest.

Table 5. Weights used in the weighted Pearson correlation between the scale of strongest response to landscape structure and average dispersal distance from the literature for each species. To calculate the weights, the values in the other two columns (number of individuals and difference in $\mathbf{X}^{\mathbf{2}}$ (see Methods)) were standardized. These were then averaged for each species. 0.99 was added to all weights to produce all nonnegative values.

Table 6. Weighted values for Pearson correlation between strongest percent forest cover spatial scale and average dispersal distance from the literature for each species. To calculate the weights, the values in the other two columns (number of individuals and difference in $\mathbf{X}^{2}$ (see Methods)) were standardized. These were then averaged for each species. 0.76 was added to all weights to produce all non-negative values. ..... 37

Table 7. Weighted values for Pearson correlation between strongest paved road density spatial scale and average dispersal distance from the literature for each species. To calculate the weights, the values in the other two columns (number of individuals and difference in $\mathbf{X}^{2}$ (see Methods)) were standardized. These were then averaged for each species. 0.90 was added to all weights to produce all non-negative values. ..... 38 
Table 8. Multiple multinomial logistic regression parameter estimates and associated Wald $\mathrm{X}^{2}$ value of anuran abundance (Index $0,1,2$, and 3 ) on percent forest cover (FOREST) and paved road density (PAVED) at the single scale at which each species had the strongest relationship to landscape structure (refer to Table 4). All predictor variables were standardized. The reference category for the equation is Index 0 , so the header "Index 1" indicates the odds of Index 1 relative to Index 0 , "Index 2" indicates the odds of Index 2 relative to Index 0 , and "Index 3 " indicates the odds of Index 3 relative to Index 0 . For Green Frog the reference category was Index 1, because there were no 0 index values, i.e., Green Frogs were present at all ponds. Local variables included in the analyses were average pond $\mathrm{pH}(\mathrm{pH})$, pond perimeter (PERIM), and percent vegetation cover of shore plants (surface vegetation (SURF.V), emergent vegetation (EMERG.V), submerged vegetation (SUBM.V), and open water

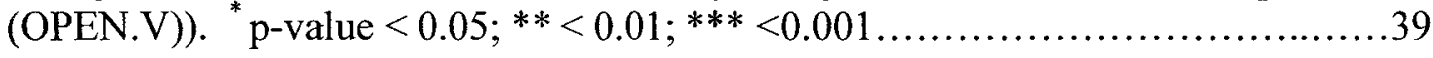

Table 9. $\mathrm{X}^{2}$ value associated with the effect of forest cover $(\mathrm{F})$ and paved road density (R) at independent scales. The primary landscape feature (either forest or paved road) and scale used in the analyses was the one that had the strongest relationship in Question 1. Analyses were performed for each anuran using multiple multinomial logistic regression. Other variables included in the analyses were average pond $\mathrm{pH}$, pond perimeter, and percent vegetation cover of shore plants. Bolded values indicate the spatial scales at which the relationship was the strongest

Table 10. The difference between the largest summed $X^{2}$ value for the effects of forest cover and paved road density at independent scales and the largest summed $\mathrm{X}^{2}$ for the effects of forest and paved road density at the same scale, on the abundance of each species (refer to Tables 4 and 6 ). ${ }^{*}$ p-value $<0.05 ; * *<0.01 ; * * *<0.001$.

Table 11. Multiple multinomial logistic regression parameter estimates and associated Wald $\mathrm{X}^{2}$ value of anuran abundance (Index $0,1,2$, and 3 ) on percent forest cover (FOREST) and paved road density (PAVED) at the individual scales at which each species had the strongest relationships with each landscape feature (refer to Table 9). All predictor variables were standardized. The reference category for the equation is Index 0 , so the header "Index 1 " indicates the odds of Index 1 relative to Index 0 , "Index 2 " indicates the odds of Index 2 relative to Index 0 , and "Index 3 " indicates the odds of Index 3 relative to Index 0 . For Green Frog the reference category was Index 1 , because there were no 0 index values, i.e., Green Frogs were present at all ponds. Local variables included in the model were average pond $\mathrm{pH}(\mathrm{pH})$, pond perimeter (PERIM), and percent vegetation cover of shore plants (surface vegetation (SURF.V), emergent vegetation (EMERG.V), submerged vegetation (SUBM.V), and open water (OPEN.V)). ${ }^{*}$ p-value $<0.05 ; * *<0.01 ; * * * 0.001$ 46 


\section{LIST OF FIGURES}

Figure 1. Study area in eastern Ontario and a small proportion of western Quebec, Canada, showing the locations of the 34 ponds (triangles). Light grey areas represent the forest, dark grey represents water, black lines represent paved roads and white areas include all other habitat types............................................. 48

Figure 2. Example of a pond with its associated landscape context. The 150,250, 500, $750,1000,1250,1500,1750$, and $2000 \mathrm{~m}$ radii buffers around the perimeter are indicated as thick black lines, the thin black lines represent paved roads, the light grey area represents forest, the dark grey represents water, and the white area includes all other habitat types.

Figure 3. $\mathrm{X}^{2}$ values associated with the effect of landscape structure (forest cover plus paved road density) from separate models at each scale for each species using multiple multinomial logistic regression analyses. American Toad ( $\square$ ), Green Frog, $(\boldsymbol{\Delta})$, Gray Treefrog $(\times)$, Western Chorus Frog $(\boldsymbol{\square})$, Spring Peeper $(\Delta)$, Northern Leopard Frog $(\bullet)$, Wood Frog (O)

Figure 4. Relationship between average known dispersal distance based on the literature and the spatial scale at which the response to landscape structure was the strongest (Table 4) for each of the study anurans $(r=0.767, \mathrm{p}$-value $=0.045)$. AMT: American Toad, GTF: Gray Treefrog, WCF: Western Chorus Frog, SPP: Spring Peeper, NLF: Northern Leopard Frog, WDF: Wood Frog, GRF: Green Frog

Figure 5. The relationship between American Toad chorus index and percent forest cover at the $500 \mathrm{~m}$ spatial scale.

Figure 6. The relationship between American Toad chorus index and paved road density at the $250 \mathrm{~m}$ spatial scale.

Figure 7. The relationship between Green Frog chorus index and percent forest cover at the $2000 \mathrm{~m}$ spatial scale.

Figure 8. The relationship between Green Frog chorus index and paved road density at the $2000 \mathrm{~m}$ spatial scale.

Figure 9. The relationship between Gray Treefrog chorus index and percent forest cover at the $500 \mathrm{~m}$ spatial scale.

Figure 10. The relationship between Gray Treefrog chorus index and paved road density at the $750 \mathrm{~m}$ spatial scale.

Figure 11. The relationship between Spring Peeper chorus index and percent forest cover at the $1500 \mathrm{~m}$ spatial scale. 
Figure 12. The relationship between Spring Peeper chorus index and paved road density

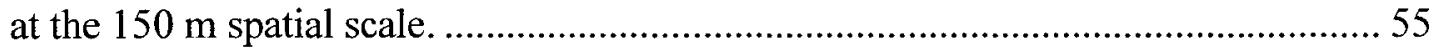

Figure 13. The relationship between Wood Frog chorus index and percent forest cover at

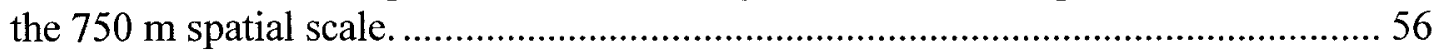

Figure 14. The relationship between Wood Frog chorus index and paved road density at

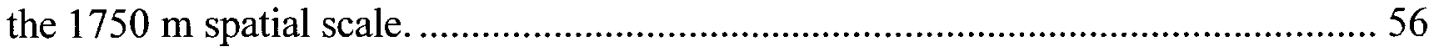

Figure 15. The relationship between Northern Leopard Frog chorus index and percent

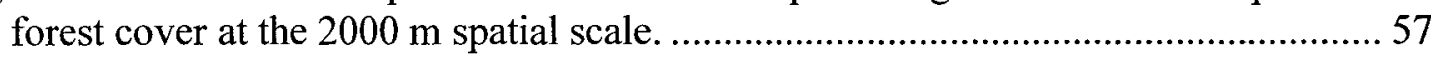

Figure 16. The relationship between Northern Leopard Frog chorus index and paved

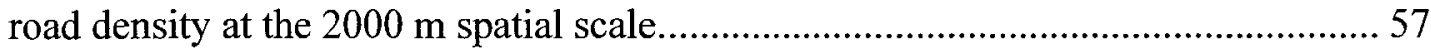

Figure 17. The relationship between Western Chorus Frog chorus index and percent forest cover at the $2000 \mathrm{~m}$ spatial scale. .......................................................... 58

Figure 18. The relationship between Western Chorus Frog chorus index and paved road

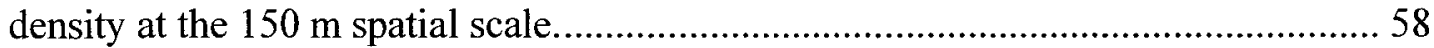

Figure 19. Relationship between average known dispersal distance based on the literature and the spatial scale at which response to percent forest cover was the strongest (Tables 9 and 10) for each of the study anurans $(r=0.599$, p-value $=0.259)$. AMT: American Toad, GTF: Gray Treefrog, WCF: Western Chorus Frog, SPP: Spring Peeper, NLF: Northern Leopard Frog, WDF: Wood Frog, GRF: Green Frog.

Figure 20. Relationship between average known dispersal distance based on the literature and the spatial scale at which response to paved road density was the strongest (Table 9 and 10) for each of the study anurans $(r=0.828$, p-value $=0.034)$. AMT: American Toad, GTF: Gray Treefrog, WCF: Western Chorus Frog, SPP: Spring Peeper, NLF: Northern Leopard Frog, WDF: Wood Frog, GRF: Green Frog. 60 


\section{LIST OF APPENDICES}

Appendix A. Largest anuran chorus indices, percent forest at each scale, paved road density at each scale, average $\mathrm{pH}$, pond perimeter, and average pond vegetation (surface vegetation (SURF.V), emergent vegetation (EMERG.V), submerged vegetation (SUBM.V), and open water OPEN.V)) used in the analysis for each anuran

Appendix B. Summary of dispersal distances from the literature of the different species of anurans in the study 64 


\section{INTRODUCTION}

Over the past 15 years studies have shown that many species of amphibians have been experiencing significant declines in population abundance (Blaustein and Wake, 1990; Blaustien et al., 1994; Pechmann and Wilbur, 1994; Hecnar, 1997; Alford and Richards, 1999; Houhlahan et al., 2000; Green, 2003; Stuart et al., 2004). Declines have been noted in 17 of Canada's 45 species of amphibians (CARCNET, 2004), with habitat loss being blamed as the primary cause (Pechmann and Wilbur, 1994; Findlay and Houlahan, 1997; Alford and Richards, 1999; Lehtinen et al., 1999; Semlitsch, 2000; Houlahan and Findlay, 2003; Pellet et al., 2004). Approximately 50\% of southern Canada's original wetlands have been lost (Lynch-Stewart, 1983), while southern Ontario has experienced a loss of $70 \%$, resulting in a significant loss in breeding areas for amphibians (Government of Canada, 1991; Ontario Ministry of Natural Resources, 1999).

Amphibians have complex life cycles, which require them to live in both aquatic and terrestrial ecosystems (MacCulloch, 2002). In addition to loss of breeding habitat, studies have shown that landscape composition surrounding breeding ponds is important for maintaining amphibian populations (e.g. Lehtinen et al., 1999; Pope et al., 2000; Marsh and Trenham, 2001; Carr and Fahrig, 2001). Lehtinen et al. (1999) even suggested that landscape context has a greater effect on amphibian assemblages than local conditions at the breeding site. In southern Ontario deforestation and road construction are sources of anthropogenic alteration to the landscape that have been shown to affect amphibians (Findlay and Houlahan, 1997).

It is important to know the spatial scale (distance) of response of amphibians to 
landscape structure around their breeding sites. Present wetland policies in Canada primarily focus on preventing further wetland loss and regulate the protection of narrow buffer zones around wetland edges. For example, the Ontario Wetland Policy recommends protecting a $120 \mathrm{~m}$ buffer of adjacent land around a wetland or a wetland complex (Ontario Ministry of Natural Resources, 1999). Some evidence suggests that this buffer size may be too narrow to adequately protect wetland biodiversity. For example, Findlay and Houlahan (1997) studied 30 south-eastern Ontario wetlands and determined that herptile (amphibian and reptile) species richness in these wetlands showed the strongest relationships to road density and forest cover at a distance of $2000 \mathrm{~m}$ from the wetland edges. It is also important to know whether different species respond to landscape structure at different scales, because regulations established based on the appropriate distance for one species may not be adequate for another species that responds at a larger scale.

At what distance around a breeding site (i.e. at what scale) does landscape structure affect amphibian populations? This scale should reflect the distance across which an organism interacts with its environment. This should depend on the typical movement range of the organism and/or the typical movement range of other organisms or substances (eg. pollutants) that affect the organism of interest (Roland and Taylor, 1997; Carr and Fahrig, 2001; Findlay et al., 2001; Vos et al., 2001; Holland et al., 2005; Thies et al., 2005).

In my study I asked 1) are the abundances of different species of anurans in eastern Ontario most strongly affected by landscape structure at different scales? and 2) does the scale at which a species responds most strongly to landscape structure reflect its 
dispersal distance? I used percent forest cover and paved road density (length of paved roads $(\mathrm{m})$ per square $\mathrm{km}$ ) as my measure of landscape structure, because both are known to affect anuran population abundance. Forests are important amphibian habitats, especially for foraging, hibernation (Hecnar, 1997), and traveling (Guerry and Hunter, 2002). Amphibian dispersal movement tends to be greater in forest habitats than open habitats because dehydration will occur faster in the open than in the forest (Rothermel and Semlitsch, 2002). Studies have indicated that amphibian population abundance and species richness are affected by the proximity and amount of forest located close to breeding ponds (e.g. Findlay and Houlahan, 1997; Hecnar, 1997; Knutson et al., 1999; Marsh and Trenham, 2001; Guerry and Hunter, 2002; Porej et al., 2004). Roads can act as a physical barrier to amphibian movement and be a major source of mortality (e.g. Vos and Chardon, 1998). Roads also alter hydrology and siltation patterns and cause the introduction of de-icing salt and other toxins into aquatic ecosystems (Forman and Deblinger, 2000; Trombulak and Frissell, 2000). Studies have indicated that anuran population abundance is significantly affected by roads (e.g. Fahrig et al., 1995, Findlay and Houlahan, 1997; Vos and Chardon, 1998; Carr and Fahrig, 2001; Findlay et al., 2001; Hels and Buchwald; 2001; Porej et al., 2004). Paved roads appear to be the major contributing factor to this effect (e.g. Findlay and Houlahan, 1997).

It is also possible that a species could respond at different scales to different landscape features. This would depend on the mechanism linking the population to the features. For example, the scale of response to habitat amount in the landscape could depend on the movement range of the organism, while the scale of response to a landscape feature causing chemical inputs to the local site (e.g., pesticides from high- 
intensity agriculture, salt from roads) could depend on how far the chemical travels through the environment. Findlay and Houlahan (1997) looked at the relationship between the species richness of four different wetland taxa and paved road density and forest amount at multiple distances around wetlands. They determined that bird richness was affected by paved road density and forest cover at $500 \mathrm{~m}$ and $2000 \mathrm{~m}$, respectively. As far as I can determine no one else has tested whether an organism responds to different landscape features at different scales. Therefore, I also asked: 3 ) does each amphibian species respond most strongly at different scales to different landscape features (forest cover and paved road density)?; and 4) if yes, then is the scale of strongest response to percent forest cover or paved road density a better indicator of species dispersal distance?

\section{Methods}

\section{Pond selection}

Thirty-four permanent ponds surrounded by varying amounts of forest (refer to Appendix A) in eastern Ontario and western Quebec, Canada, were surveyed (Figure 1). All of the ponds were at least $4 \mathrm{~km}$ from each other to prevent pseudo-replication. There was no urban development within $2 \mathrm{~km}$ of each pond and less than $3 \%$ of the land cover within $2 \mathrm{~km}$ of each pond was composed of water. This was determined from digitized 1: 50,000 National Topographic Data Base (1985-1995) (NTDB) maps using ArcView 3.2 (Environmental System Research Institute, 1999). Ponds were also chosen to ensure easy 
accessibility at night and lack of predatory fish (Hecnar and M'Closkey, 1997). Old quarries or ponds lined with concrete were excluded from the study.

\section{Population abundance surveys}

Breeding chorus surveys were conducted to determine relative population abundance of all anuran species in the study area: American Toad (Bufo americanus), Western Chorus Frog (Psuedacris triseriata triseriata), Gray Treefrog (Hyla versicolor), Spring Peeper (Psuedacris crucifer), Bullfrog (Rana catesbeiana), Mink Frog (Rana septentrionalis), Wood Frog (Rana sylvatica), Green Frog (Rana clamitans), Pickerel Frog (Rana palustris), and Leopard Frog (Rana pipiens) (CARCNET, 2004). Anuran males have species specific calls that advertise their position during the breeding season to potential mates (Zimmerman, 1994), allowing their relative abundances to be easily quantified in a call index (Scott and Woodward, 1994). Anuran abundance data were collected in six call surveys during peak anuran breeding season, from April 15 to July 6 , 2004. The six surveys were evenly dispersed throughout the breeding season to ensure that all anuran species were heard (after Laan and Verboom, 1990). The largest chorus index recorded at each pond for each species over the 6 surveys was used as the response variable for that species at that pond.

Due to seasonal restrictions one pond was not surveyed for Green Frogs, Bullfrogs, and Mink Frogs and another site was not surveyed for Western Chorus Frogs and Wood Frogs. Access was restricted to the first of these ponds after May 21, 2004 (after the third survey) because bulls were pastured in the field surrounding the pond after this date. The other site was unavailable until May 31, 2004 (until the fourth survey) because it was located on a campground that was not accessible before that date. 
My 24 volunteers and I performed the surveys following protocols in Lepage et al. (1997), Pope et al. (2000), and Weeber and Vallianatos (2000). We conducted surveys between half an hour after sunset and midnight. The number of calls for each species within a 5 minute time span per site (with the time span being composed of the sum of the pauses in background noise) was counted, commencing 1 minute after arrival. The number of individuals of each species heard was placed into one of four abundance categories: Index 0 - no individuals calling; Index 1 - individual(s) can be counted, calls are not overlapping; Index 2 - calls of fewer than 15 individuals can be distinguished, but there is some overlapping of calls; and Index 3 - calls of 15 or more individuals.

Listening location by the pond remained consistent between sampling dates. The Marsh Monitoring Program Training audio tape produced by the Canadian Wildlife Service was used to train volunteers.

Anuran surveys were performed only when weather conditions were ideal. The first survey was performed when the minimum day temperature was above $8^{\circ} \mathrm{C}$ and all the other surveys were performed when night time temperature was at least $8^{\circ} \mathrm{C}$. Surveying did not occur when the wind speed was greater than 3 on the Beaufort scale $(\geq$ $20 \mathrm{~km} / \mathrm{hr})$.

The sites were divided among ten routes with 3 to 7 sites per route. The routes were randomly assigned to volunteers for each survey period and the direction in which each route was driven was changed between survey periods (forwards, backwards, and by starting at various points in the middle of the route). 


\section{Local variables}

Local pond attributes - percent vegetation cover of shore plants, $\mathrm{pH}$ and pond perimeter - were collected between June 10 and 29, 2004 at each pond to control for habitat differences in the statistical models.

The abundance of amphibians found in ponds can be influenced by shore vegetation quality, water quality and pond perimeter. Percent vegetation cover of shore plants was chosen as a local pond variable because pond vegetation provides calling sites for anuran, protection from predators and structure for attachment of egg masses (Stebbins and Cohen, 1997; Hecnar and Hecnar, 1999; Woodford and Meyer, 2003). Poor water quality (such as low $\mathrm{pH}$ ) negatively impacts amphibian populations by reducing hatching success and reducing growth of tadpoles (e.g. Gosner and Black, 1957; Freda and Dunson, 1985; Pierce, 1985). Pond perimeter was chosen as a control variable since larger ponds are generally more diverse and tend to contain larger species populations (Hecnar and M'Closkey, 1998; Ricklefs and Lovette, 1999).

Water $\mathrm{pH}$ measurements were taken at 31 of the ponds. Pond $\mathrm{pH}$ was not taken at three of the ponds because they were not accessible, hence only the 31 sites with available water $\mathrm{pH}$ values were used in the analysis. $\mathrm{pH}$ was measured using a Fisher Scientific accumet portable AP62 pH/mV meter and Hanna Instruments (HI 98129) waterproof $\mathrm{pH}, \mathrm{EC} / \mathrm{TDS}$ and temperature meter, at a depth of $5 \mathrm{~cm}, 1 \mathrm{~m}$ from the shoreline (after Pope, 1996; Carr, 1999) in four locations, approximately evenly spaced around the perimeter of the pond. For ponds whose perimeters were not completely accessible 3 to $4 \mathrm{pH}$ readings were taken around the portion of the pond edge that was 
accessible. An average $\mathrm{pH}$ was determined for each pond where $\mathrm{pH}$ readings were recorded.

For 24 of the ponds, percent vegetation (emergent, surface, submerged plants, and open water) was estimated along $2 \mathrm{~m}$ line transects extending at right angles from the shoreline. The spacing between transects was determined based on the estimated perimeter of the pond. Transects were spaced $19 \mathrm{~m}, 38 \mathrm{~m}, 57 \mathrm{~m}, 76 \mathrm{~m}$, and $95 \mathrm{~m}$ apart for ponds with perimeters less than $219 \mathrm{~m}, 280 \mathrm{~m}, 487 \mathrm{~m}, 681 \mathrm{~m}$, and $1737 \mathrm{~m}$, respectively. This ensured representative vegetation sampling for each pond and that there were at least four transects at each pond (Pope, 1996). Emergent plants were defined as plants such as grasses, sedges, and rushes that are rooted in pond substrate and have stems and leaves above the pond surface. Plants that floated on the water surface, such as water lilies, water ferns, and duckweed, were considered surface plants, while plants with long sinuous or bushy and very branched leaves that are completely under water were submerged plants (ex. Pondweed, hornworts, and waterweeds) (Reid, 1987). I averaged the percent cover values across transects for each vegetation category at each pond. I rounded the vegetation percent cover values to the nearest $10 \%$ to compensate for variation in observer estimation.

Transect sampling was not performed at seven ponds due to unsafe conditions. For these 7 ponds a general estimation of the vegetation cover around the perimeter was determined by two surveyors.

The perimeter of each pond, in meters, was determined by walking around the perimeter of the pond and collecting GPS points that were transferred to ArcView 3.2. For the ponds that were not fully accessible, pond perimeter was determined from 
National Topographic Data Base (NTDB) maps (after Laan and Verboom, 1990; Hecnar, 1997; Pope et al., 2000; Carr and Fahrig, 2001). Pond perimeter was calculated using ArcView 3.2.

Pond perimeter ranged from $37 \mathrm{~m}$ to $1737 \mathrm{~m}$ and averaged $335 \pm 59 \mathrm{~m}$ (standard error). Pond depth (measured $2 \mathrm{~m}$ from the shore line at even spacing around the pond perimeter) averaged $36 \pm 4 \mathrm{~cm}$, ranging from $13 \mathrm{~cm}$ to $70 \mathrm{~cm}$. Dominant pond vegetation was typically cattails (Typha sp.), reeds (Phragmites sp.), sedges (Carex sp.), water plantains (Sagittaria sp.), and water lilies (Nymphaea sp.). Pond vegetation extending 2 $\mathrm{m}$ from the shoreline was comprised of $34.3 \pm 3.6 \%$ emergent vegetation (range 0 to $80 \%$ ), $7.1 \pm 1.6 \%$ surface vegetation (range 0 to $32.5 \%$ ), $14.8 \pm 3.2 \%$ submerged vegetation (range 0 to $62 \%$ ), and $50.7 \pm 4.0 \%$ open water (range $16.5 \%$ to $100 \%$ ).

\section{Landscape variables}

Using ArcView 3.2 (Environmental System Research Institute, 1999), I created $150 \mathrm{~m}$, and $250 \mathrm{~m}$ to $2000 \mathrm{~m}$ radii buffers (at $250 \mathrm{~m}$ intervals) around the perimeter of each pond (Figure 2). Forest cover and paved road density were quantified at each scale using digitized 1: 50,000 National Topographic Data Base (1985-1995) (NTDB) maps and the National Road Network, Canada, Level 1 maps (2002), respectively.

To evaluate the accuracy of the NTDB maps I digitized the forest cover within $1000 \mathrm{~m}$ of a subset of six ponds using 1:15,000 Ottawa-Carleton Region 2002 air photos, and determined the percent forest cover for comparison with the NTDB values. The six sites were chosen to represent a large range of percent forest cover (3.7 to 87.1\%) and locations throughout the study area. There was an average $1.1 \%$ (range 0.2 to $1.7 \%$ ) difference in forest cover between the air photos and NTDB maps. 
Percent forest cover and paved road density in the landscape around each pond varied among the landscapes surrounding the 34 study ponds at each spatial scale (Tables 1 and 2, respectively). Appendix A shows the percent forest cover and paved road density, in $\mathrm{m} / \mathrm{km}^{2}$, for each spatial scale around each pond. The correlation between forest cover and paved road density was generally low (Table 3).

\section{Analyses}

\section{Are abundances of different species of anurans in eastern Ontario most strongly}

\section{affected by landscape structure at different scales?}

I addressed this question by conducting separate multiple multinomial logistic regression analyses of the abundance of each species of anuran on landscape structure variables (forest amount and paved road density) at each of nine scales, i.e., within 150 $\mathrm{m}$, and $250 \mathrm{~m}$ to $2000 \mathrm{~m}$ (at $250 \mathrm{~m}$ intervals) of the ponds. Three of the ten species (Bullfrog, Mink Frog, and Pickerel Frog) were excluded from the analysis due to their being present at fewer than five of the 31 ponds. I also included local pond characteristics $-\mathrm{pH}$, pond vegetation, and perimeter - to control for pond effects. Only the vegetation type that had the strongest relationship to each anuran species (as determined through a preliminary analysis) was included in the model for that species. All local and landscape variables were standardized before being entered into analyses, so that their relative effects could be evaluated by comparing parameter estimates.

Multinomial logistic regression is similar to logistic regression. However, it allows the response variable to have more than two categories. The multinomial logistic regression equation is as follows with each response category being paired with a 
reference/ baseline category.

Equation 1.

$$
\begin{aligned}
& \pi_{\mathrm{ik}}=\mathrm{e}^{\mathrm{Zik}} /\left[\mathrm{e}^{\mathrm{Zil}}+\mathrm{e}^{\mathrm{Zi} 2}+\ldots+\mathrm{e}^{\mathrm{Zik}}\right] \\
& \text { where } \pi_{\mathrm{ik}}=\text { the probability that the } \mathrm{i}^{\text {th }} \text { case falls in category } \mathrm{k} \text {, and } \\
& \begin{array}{r}
\mathrm{Z}_{\mathrm{ik}}=\text { the values of the } \mathrm{k}^{\text {th }} \text { unobserved variables } \\
=\alpha_{\mathrm{k}}+\beta_{\mathrm{k} 1} \mathrm{x}_{\mathrm{i} 1}+\beta_{\mathrm{k} 2} \mathrm{x}_{\mathrm{i} 2} \ldots+\beta_{\mathrm{kJ}} \mathrm{x}_{\mathrm{iJ}} \\
\text { where } \mathrm{x}_{\mathrm{iJ}}=\text { value of the } \mathrm{J}^{\text {th }} \text { predictor for the ith case } \\
\beta_{\mathrm{kJ}}=\mathrm{J}^{\text {th }} \text { coefficient for the } \mathrm{k}^{\text {th }} \text { unobserved variable } \\
\mathrm{J}=\text { number of predictors }
\end{array}
\end{aligned}
$$

Since for this question I was interested in determining whether different species responded to landscape structure at different scales (and not the independent effects of forest and roads) I summed the $\mathrm{X}^{2}$ values for the effects of forest cover and road density for each species at each scale. The scale at which each anuran had the strongest response to landscape structure was then the scale at which the summed $\mathrm{X}^{2}$ value was largest.

\section{Does the scale at which each species responds most strongly to landscape structure reflect its dispersal distance?}

A literature review was performed to determine the known dispersal distances for the anurans in the study. All dispersal information available and sample sizes from original studies were recorded for each anuran in each study. When the literature provided more than one dispersal distance an average dispersal distance was determined by calculating a weighted mean of the dispersal distances, where the weighting was based on the sample sizes in the individual studies. The scale at which each anuran species had its strongest response to landscape structure was plotted against the average dispersal distance for that species and a weighted Pearson Correlation was performed to determine their relationship. 
I used a weighted correlation for two reasons. First, dispersal distance estimates for some species were based on many individuals whereas for others they were only based on a few individuals (Appendix B). Second, for some species the change in strength of response to landscape structure was strongly peaked, providing a more definite estimate of spatial scale of response than for species with similar strength of response across all scales (Table 4, Figure 3). I determined the strength of the peak by taking the difference in $\mathrm{X}^{2}$ value between the scale where the relationship was strongest and the scale where the relationship was weakest. I standardized the dispersal distance sample size values and the $\mathrm{X}^{2}$ difference values and averaged them together to get the overall weight for each species. Finally, I added the smallest value to all weights to produce positive weights for all species (Table 5).

\section{Does each species respond most strongly at different scales to different landscape features (forest cover and paved road density)?}

From the analysis from question 1, I determined which landscape feature (either forest cover or paved road density) had the strongest relationship to the abundance of each species, and at which scale. I then conducted multiple multinomial logistic regressions for each species, considering each possible scale for the other variable. As in question 1 , for each species I added the $\mathrm{X}^{2}$ values for the effects of forest cover and road density. I tested whether there was a significant increase in the summed $\mathrm{X}^{2}$ values using different scales for the two landscape features over the $\mathrm{X}^{2}$ value in which the scales were assumed to be the same (i.e., from question 1). 


\section{If yes, is the scale of strongest response to percent forest cover or paved road density a better indicator of species dispersal distance?}

The average dispersal distance determined from the literature for each species (see question 2) was plotted separately against the scale at which each anuran had its strongest response to forest cover and paved road density. Separate frequency variables for forest cover and paved road density were determined for the weighted Pearson correlations (see question 2) (Table 6 and 7).

\section{RESULTS}

Ten species of anuran were heard calling during the survey period. The Green Frog was the most ubiquitous species, occurring in all the ponds, followed by Spring Peeper which was found in $94 \%$ of the ponds. These species did vary in abundance among ponds, so they were included in the analyses. Other common species were the Gray Treefrog (79\% of sites), Northern Leopard Frog ( $68 \%$ of sites), Wood Frog ( $67 \%$ of sites) and American Toad (62\% of sites). Western Chorus Frogs were less common and only present in 6 of the ponds ( $18 \%$ of sites). Due to their rarity, the Pickerel Frog (4 ponds), Mink Frog ( 3 ponds), and Bullfrog ( 3 ponds) were excluded from the analyses.

\section{Are abundances of different species of anurans in eastern Ontario most strongly affected by landscape structure at different scales?}

The different species of anurans appeared to be most strongly affected by landscape structure at different scales (Table 4). The multiple multinomial logistic regression parameter estimates and associated Wald $\mathrm{X}^{2}$ values at the scale with the largest 
effect of landscape structure for each species, are shown in Table 8.

\section{Does the scale at which each species responds most strongly to landscape structure reflect its dispersal distance?}

The average known dispersal distance for the seven anuran species are shown in Appendix B. The scales at which species responded to landscape structure were positively correlated with the dispersal distances of the species $(r=0.767, \mathrm{p}$-value $=$ 0.045) (Figure 4).

\section{Does each species respond most strongly at different scales to different landscape features (forest cover and paved road density)?}

For three species, the model that considered different scales of response for the two landscape features was a significant improvement over the model that assumed the same spatial scale of response to forest cover and paved road density (Tables 9 and 10). American Toads responded most strongly to forest cover at $500 \mathrm{~m}$ and to paved road density at $250 \mathrm{~m}$. Spring Peepers and Western Chorus Frogs responded most strongly to forest cover at $1500 \mathrm{~m}$ and $2000 \mathrm{~m}$, respectively, and to paved road density at $150 \mathrm{~m}$.

The multiple multinomial logistic regression parameter estimates and associated Wald $\mathrm{X}^{2}$ values at the scales with the largest effects of each landscape structure variable independently, for each species, are shown in Table 11.

The relationships between abundance of different species and percent forest cover and paved road density at the spatial scales at which each relationship was strongest (refer to Table 9) are shown in Figures 5 to 18. 


\section{If yes, is the scale of strongest response to percent forest cover or paved road density} a better indicator of species dispersal distance?

The scales at which species respond to percent forest cover and paved road density were positively correlated with dispersal distance of the species. The weighted correlation for forest cover was lower than the weighted correlation using a single scale of response for each species to both landscape features (Figure 19). Conversely, the weighted correlation for paved road density was higher than the weighted correlation using a single scale of response for each species to both landscape features (see results for question 2, above) (Figure 20). The scales at which species responded to paved road density were significantly positively correlated with the dispersal distances of the species $(r=0.828, \mathrm{p}$-value $=0.034)$. The correlation between the scale at which species respond to forest cover and dispersal distance was positively correlated but not statistically significant $(r=0.599$, p-value $=0.259)$.

\section{DISCUSSION}

Different species of anurans appeared to respond at different scales to the landscape structure, measured as amount of forest and paved road density, surrounding their breeding sites. The scales at which species responded to landscape structure ranged from $500 \mathrm{~m}$ for the American Toad to at least $2000 \mathrm{~m}$ for the Northern Leopard Frog, the Green Frog, and the Western Chorus Frog. This is an important finding because most multi-species studies have been performed using a single scale, often because the landscape information was available only at that scale (e.g. McGarigal and McComb; Trzcinski et al., 1999; Knutson et al., 1999; Guerry and Hunter, 2002; Vance et al., 2003). 
It seems likely that such studies miss the responses of species that respond to the landscape at very different scales than the one chosen by the researcher. Due to this, one could misinterpret which species respond to landscape structure and the importance of landscape structure relative to local variables. There is a recent trend towards multispecies, multi-scale studies which should alleviate this problem (e.g. Steffan-Dewenter et al., 2002; Holland et al., 2004; Homan et al., 2004; Knutson et al., 2004; Herrmann et al., 2005; Holland et al., 2005).

There have been a few studies that evaluated the scale at which landscape context affects individual amphibian species, to which I can compare some of my results (Pope et al., 2000; Carr and Fahrig, 2001; Knutson et al., 2004; Porej et al., 2004; Herrmann et al., 2005; Homan et al., 2004). Most of these studies included forest cover as a potential predictor variable. Only one study (Carr and Fahrig, 2001) evaluated the scale at which roads affect amphibian populations. My study is the first to evaluate the scale of response of Western Chorus Frogs to forest cover (strongest response at $2000 \mathrm{~m}$ ) and the first to evaluate the scale of response of American Toads, Green Frogs, Gray Treefrogs, Wood Frogs, Spring Peepers, and Western Chorus Frogs to road density (strongest responses at $250 \mathrm{~m}, 2000 \mathrm{~m}, 750 \mathrm{~m}, 1750 \mathrm{~m}, 150 \mathrm{~m}$, and $150 \mathrm{~m}$, respectively).

In several cases, the scales of response that I found are reasonably consistent with those found in other studies. Gray Treefrogs showed the strongest relationship to forest cover at $500 \mathrm{~m}$ in my study, which was similar to Knutson et al. (2004), who found the strongest response at $1000 \mathrm{~m}$. Herrmann et al. (2005) determined that Spring Peepers and Green Frogs were affected most strongly by forest cover at the $1000 \mathrm{~m}$ and $1500 \mathrm{~m}$, respectively, which was similar to the $1500 \mathrm{~m}$ scale and $2000 \mathrm{~m}$, respectively, that I 
found. Porej et al., (2004) found that Wood Frogs showed the strongest response to forest cover within 200 to $1000 \mathrm{~m}$ which includes the $750 \mathrm{~m}$ scale determined in my study. Finally, Carr and Fahrig (2001) determined that Northern Leopard Frogs were most strongly affected by traffic density at $1500 \mathrm{~m}$, which is similar to my result of 2000 $\mathrm{m}$ for paved road density.

However, some of the scales I found are not consistent with the literature.

Herrmann et al. (2005) determined that American Toad, Gray Treefrogs, and Wood Frogs were affected by forest cover at $100 \mathrm{~m}, 1500 \mathrm{~m}$ and $2000 \mathrm{~m}$, respectively, while I found the strongest effects for these species at $500 \mathrm{~m}, 500 \mathrm{~m}$, and $750 \mathrm{~m}$ respectively. One possible reason for the differences could be that there was a negative correlation $(r=-0.6)$ between forest cover and road density among sites in the Herrmann et al. (2005) study. I found generally large scales of response to road density for the Gray Treefrog and the Wood Frog (750 m and $1750 \mathrm{~m}$ respectively), so it is possible that the Herrmann et al. (2005) results for forest cover are confounded by responses to road density. An important feature of my study is the low correlation between forest cover and paved road density, which minimizes this problem (Table 3).

Knutson et al. (2004) found that Spring Peepers were affected by forest cover at $2500 \mathrm{~m}$ while I determined that they were affected at the $1500 \mathrm{~m}$ scale. This difference is likely due to the fact that Knutson et al. (2004) evaluated landscape structure at only three scales $(500 \mathrm{~m}, 1000 \mathrm{~m}, 2500 \mathrm{~m})$. It is possible that in their study the forest cover at 1500 $\mathrm{m}$ was more similar to the forest cover at $2500 \mathrm{~m}$ than it was to the forest cover at 1000 m. This highlights another important feature of my study. Since I evaluated landscape structure at every $250 \mathrm{~m}$ (Figure 2), I was able to identify the scale of response more 
precisely than studies that have used a coarser resolution.

Finally, I found that Wood Frogs were affected the strongest by forest cover at $750 \mathrm{~m}$ while Homan et al. (2004) found the strongest response at $300 \mathrm{~m}$. Homan et al. (2004) performed their study in a suburban area predominantly comprised of agriculture, housing developments, and industry. Wood Frogs avoid crossing fields, pastures, lawns, clearcuts, and roads (Gibbs, 1998; deMaynadier and Hunter, 1999; Rothermel and Semlitsch, 2002). Therefore, the small scale of response they found may be due to these barriers which could have limited Wood Frog movement through their landscape. An important feature in my study was the lack of urban land cover within my landscapes.

This is the first study to directly test the hypothesis that the scale of response to landscape structure is an indicator of the dispersal scale of the organism. I found a significant positive cross-species correlation between dispersal distance and the scale of strongest response to landscape structure (Figure 4). I am aware of only one other study that indirectly tested this hypothesis. Holland et al. (2005) determined the spatial scales at which 31 species of longhorned beetles responded to forest amount and compared this to their body sizes, on the assumption that movement range should increase with body size. They found a positive correlation between body size and the scale of response to the landscape.

The weighted correlation between dispersal distance and scale of response to paved road density (Figure 19) was larger than the correlation between dispersal distance and response to forest cover (Figure 20). This result was not expected. I expected the scale of response to habitat in the landscape (forest or open cover) to be dictated by movement distance of the organism, while the scale of response to roads would be at least 
partly related to the distance moved by chemical pollutant draining off the roads.

Contrary to this expectation, my results seem to suggest that dispersing amphibians are more sensitive to roads than to other land cover types such as forest. Roads can influence amphibian dispersal ability by acting as physical barriers and increasing mortality (Vos and Chardon, 1998). Finally, it is possible that the scale of amphibian response to forest cover is affected by both the scale of amphibian movement and the scales of movement of their terrestrial predators, such as snakes, birds, small mammals, and raccoons (Harding, 1997). This would obscure the relationship between dispersal distance and scale of response to forest cover.

The weighted correlation was strongly affected by the Northern Leopard Frog. This is appropriate because we had confidence in both the dispersal distance estimate (due to the large sample size) and the spatial scale estimate (due to the large difference between scales in the strength of the relationship) for this species. The Spring Peeper also had a large weight and the Gray Treefrog and Wood Frog had the smallest weights (refer to Table 5,6, and 7). Overall, weighting the values resulted in a stronger correlation between dispersal distance and scale of response to the landscape, because it placed more weight on species that improved the positive relationship.

If the scale of response to landscape structure is an indication of movement distances, the large scales I found are inconsistent with the generally held notions that amphibians have low dispersal abilities (Bellis, 1965; Reading et al., 1991; Lehtinen et al., 1999; Smith and Green, 2005) and high site fidelity (Dole, 1965; Reading et al., 1991; Pechmann et al., 2001). These assumptions are likely a result of limited knowledge about dispersal (Dole, 1971; Marsh et al., 1999; Pope et al., 2000; Smith and Green, 2005). 
Smith and Green (2005) compiled a comprehensive list of the longest distances moved by 53 species of anuran from the literature and determined that anurans disperse an average maximum distance of $2.02 \mathrm{~km}$. This value agrees with my results and those of other anuran landscape studies which have indicated a distance of $2 \mathrm{~km}$ from a pond as the scale that encompasses most effects of landscape structure on amphibians in Ontario (e.g. Findlay and Houlahan, 1997; Findlay and Bourdages, 2000).

This study is the first to evaluate whether individual species respond to different landscape features at different scales. I found that American Toads, Spring Peepers and Western Chorus Frogs responded at different scales to forest cover and paved road density. However, the scales of response of the American Toad were quite similar for road density and forest cover; they responded most strongly to forest cover at $500 \mathrm{~m}$ and to paved road density at $250 \mathrm{~m}$. In contrast, Western Chorus Frogs and Spring Peepers responded at much smaller scales to paved road density $(150 \mathrm{~m})$ than to forest cover (2000 $\mathrm{m}$ and $1500 \mathrm{~m}$, respectively). In both cases, the scale of response to road density was well below the expected value (Figure 20). Both Spring Peepers and Western Chorus Frogs responded positively to paved road density. Roads are often associated with shallow temporary fishless ditches and ponds which are preferred breeding habitats for both Spring Peepers and Western Chorus Frogs (Harding, 1997). Therefore, the small-scale impact of roads on these species may reflect the production of ideal breeding habitat, rather than the movement range of these species. During the remainder of the year, Western Chorus Frogs and Spring Peepers move across the landscape to find sites for foraging and hibernating in forest, which could explain the larger scale of response to forest cover. 


\section{Individual species responses}

\section{a) American Toads}

I found that American Toads were negatively affected by forest cover and negatively by paved road density. American Toads are habitat generalists, but they prefer open areas (e.g. meadows, gardens, parks, and agricultural areas) (DeGraaf and Rudis, 1983; Harding, 1997; CARCNET, 2004). Therefore, the apparent negative relationship to forest cover most likely indicates a positive relationship to open area. Guerry and Hunter (2002) also found a negative association between American Toad abundance and forest cover; however, Lehtinen et al. (1999) found that American Toads were positively affected by forest cover. The difference between my results and those of Lehtinen et al. (1999) could be due to the low forest cover (forest wetlands: mean $\pm \mathrm{SD}=18.4 \pm 12.0 \%$; prairie wetlands: mean $\pm \mathrm{SD}=2.7 \pm 2.3 \%$ ) surrounding their sites, reducing the potential negative influence of forest cover. The positive relationship to forest cover was only detected when they combined both of the studies ecoregions (i.e. forest wetland and prairie wetland). Also, there was a negative relationship at each scale between the combined ecoregions forest cover and road density which could explain the positive relationship to forest since American Toads prefer open areas which are often associated with road. No other study has looked at the effect of paved road density on American Toads. American Toads actively move through their landscape, especially when moving to and from their breeding site (CARCNET, 2004), which increases their chance of encountering roads. 


\section{b) Green Frogs}

Green Frogs did not show any significant relationships to landscape structure. Similarly, Carr and Fahrig (2001) found that Green Frog abundance was not affected by traffic density. Green Frogs are habitat generalists and have strong site fidelity to the pond they hibernate, breed, and forage by (Harding, 1997; MacCulloch, 2002). Hence adult Green Frogs do not move far within the landscape surrounding their breeding pond, which would result in the lack of relationship between landscape structure and Green Frog abundance. However, Guerry and Hunter (2002) found that Green Frog presence had a weak positive relationship to forest cover (Odds ratio $=1.009, \mathrm{p}=0.027$ ). It is possible the relation they observed was due to our difference in sample size (this study: $\mathrm{n}$ $=33$; Guerry and Hunter, 2002: $\mathrm{n}=116$ ). It is possible that if I had this larger sample size I may have also observed a weak positive relationship between Green Frogs and forest cover.

\section{c) Gray Treefrogs}

Gray Treefrogs had a negative relationship to paved road density and to percent forest cover. This is the first study to evaluate the effect of road density on Gray Treefrogs. Contrary to their name, Gray Treefrogs are not limited to forests and are often found on moss and lichen, in old fields, well planted suburban yards, and shrubby areas (DeGraaf and Rudis, 1983; Harding, 1997; CARCNET, 2004). However, Knutson et al. (2004) found that Gray Treefrogs were positively related to forest cover. This is most likely because in their data there were strong correlations between forest cover, grassland amount, and wetland area. Knutson et al. (2004) does not indicate the direction of the correlation between forest and grasslands, however if it was positive forest cover in their 
study would be an indicator of overall habitat amount.

\section{d) Spring Peepers}

I found a positive effect of forest cover and paved road density on Spring Peeper abundance. Knutson et al. (2004) also found that Spring Peepers are positively affected by forest cover, but this is the first study to evaluate the effect of paved road density on Spring Peepers. Spring Peepers are very terrestrial and tend to forage and hibernate in forests. Spring Peepers like to breed in shallow temporary fishless ditches and ponds which are often associated with roads (Harding, 1997).

\section{e) Wood Frogs}

I found that Wood Frogs are positively affected by forest cover and not affected by paved road density. Other studies concur with the positive effect of forest cover (Guerry and Hunter, 2002; Homan et al., 2004; Proej et al., 2004; Rubbo and Kiesecker, 2005). Wood Frogs are terrestrial, tend to remain in forested areas, and prefer to breed in ponds surrounded by trees (Wright and Wright, 1949; CARCNET, 2004), explaining the positive association with forest cover. They prefer to move and hibernate in moist forested areas and will only move across open areas if it is required to reach breeding ponds (Harding, 1997). This could explain the lack of response to paved road density observed in this study since they would avoid locations such as roads during the foraging season. However Findlay et al. (2001) indicate that Wood Frog presence was negatively affected by roads. Findlay et al. (2001) results may be due to the quality of their data. They used data from surveys conducted for the Ontario Ministry of Natural Resources wetland evaluation process which were not conducted with the intention of obtaining a 
complete species list. Each wetland used in the Findlay et al. (2001) data set was surveyed between 1986 and 1993 at least twice a year during late April to early May and late May to early June via evening call and visual day surveys. Wood Frogs begin breeding the first warm day of spring (late March - early April) and are present at the breeding pond for only a short period of time and are rarely found in water except during breeding season (Harding 1997) and hence the Ontario Ministry of Natural Resources wetland evaluations could have missed them.

\section{f) Northern Leopard Frogs}

Northern Leopard Frog abundance was negatively affected by forest cover and paved road density in this study. Guerry and Hunter (2002) also found that Northern Leopard Frog presence was negatively affected by forests and Carr and Fahrig (2001) also found that they were negatively affected by roads. Studies that looked at the effect of grasslands on Northern Leopard Frogs observed positive relationships (Pope et al., 2000; Knutson et al., 2004), which could be interpreted as the same as a negative relationship to forest cover. Northern Leopard Frogs actively move through the landscape, moving from their hibernation site to their breeding pond and then to open foraging areas (Harding, 1997; CARCNET, 2004), and will potentially encounter roads at some point. Their preference for open summer foraging areas, such as meadows and fields, explains their negative relationship to forest cover and frequent movement explains their negative relationship to roads.

\section{g) Western Chorus Frogs}

Western Chorus Frog abundance was positively affected by forest cover and 
paved road density. There is very little literature on Western Chorus Frogs, but Knutson et al. (2004) determined that they had a positive relationship with grasslands. As mentioned above, this could be due to a strong positive correlation between forest cover and grassland amount in their data set; however the direction of the correlation was not indicated. Western Chorus Frogs are terrestrial and tend to forage in forest areas and meadows but prefer areas with logs, rocks, and leaf litter where they can hide and hibernate. The positive effect of roads on Western Chorus Frogs could result from their preference to breed in shallow temporary fishless ditches and ponds (Harding, 1997) that are often associated with roads,

\section{Conservation Implications}

Like other studies (e.g. Findlay and Houlahan, 1997; Lehtinen et al., 1999; Findlay and Bourdages, 2000; Pope et al., 2000; Carr and Fahrig, 2001; Findlay et al., 2001; Guerry and Hunter, 2002; Homan et al., 2004; Knutson et al., 2004; Proej et al., 2004; Herrmann et al., 2005), I found that the structure of the landscape surrounding breeding ponds significantly affected the abundance of amphibians above and beyond the effects of local pond size and quality. Therefore, management should occur at the landscape scale and not just the local scale. I found that different species are affected by landscape structure at different scales and that some species, such as the American Toad, Spring Peeper and Western Chorus Frog are affected by different landscape features (i.e. forest cover and paved road density) at different scales. Managers could use the information from this study on species responses to scale and landscape features to map potentially important breeding pond locations on private and public lands, and to estimate the general status of the region's anuran populations. 
Some species responded most strongly to landscape structure at very large distances $(2000 \mathrm{~m})$ from the breeding site. Currently, the Ontario Wetland Policy recommends protecting a $120 \mathrm{~m}$ buffer of adjacent land around a wetland or a wetland complex (Ontario Ministry of Natural Resources, 1999). My results imply that this buffer size is insufficient to protect amphibians. However, fully protecting buffers of $2000 \mathrm{~m}$ around all ponds and wetlands is not practical. Given the number and spacing of ponds and wetlands in our area, this would essentially suggest that the entire region would need to be fully protected. The buffer system therefore needs to be augmented with regional land management policies and programs that are developed through partnerships of landowners, government agencies, and conservation groups.

My results also suggest changes are needed to the current wetland evaluation criteria in Ontario. Such evaluations are performed prior to developing in and around a wetland in Ontario. Wetland evaluations include a review of the wetland's general biodiversity components, including an assessment of provincially or nationally vulnerable, threatened or endangered species. However, the evaluation does not consider the structure of the surrounding landscape, such as road density and forest cover (Findlay et al., 2001). The importance and scale of these landscape effects on amphibians suggests that the policy should be changed to include landscape criteria. 


\section{REFERENCES}

Alford, R.A. and S.J. Richards. 1999. Global amphibian declines: A problem in applied ecology. Annual Review of Ecological Systems 30: 133-165.

Bellis, E.D. 1965. Home range and movement of the Wood Frog in a northern bog. Ecology 46 (1/2): 90-98.

Berven, K.A. and T.A. Grudzien. 1990. Dispersal in the wood frog (rana sylvatica): implications for genetic population structure. Evolution 44: 2047-2056.

Blaustien, A. and D. Wake. 1990. Declining amphibian populations: A global phenomenon? Trends in Ecology and Evolution 5(7): 203-204.

Blaustien, A., D. Wake, and W. Sousa. 1994. Amphibian Declines: Judging Stability, Persistence, and Susceptibility of Populations to Local and Global Extinctions.

Conservation Biology 8(1): 60-71.

Canadian Amphibian and Reptile Conservation Network (CARCNET). 2004. Amphibian Tour of Canada - Ontario. Online: www.carcnet.ca. (Retrieved: 01/20/05)

Carr, L.W. 1999. The impact of vehicular traffic on two frog populations of different vagility, Rana pipiens and Rana clamitans. M.Sc. Thesis. Carleton University, Ottawa, Ontario.

Carr, L.W. and L. Fahrig. 2001. Effect of road traffic on two amphibian species of different vagility. Conservation Biology 15(4): 1071-1078.

City of Ottawa. Surveys and Mapping. Air Photos, Spring 2002: 1:15,000. 360050300 [computer file]. Ottawa, City of Ottawa, 2004.

DeGraaf, R.M. and D.D. Rudis. 1983. Amphibians and Reptiles of New England: Habitats and Natural History. The University of Massachusetts Press, Amherst.

deMaynadier, P.G. and M.L. Hunter. 1999. Forest canopy closure and juvenile emigration by pool-breeding amphibians in Maine. Journal of Wildlife Management 63:441-450.

Dezell, D.E. 1958. Spatial movement and growth of Hyla crucifer. Ph. D. Dissertation, University of Michigan, Ann Arbor, Michigan.

Dole, J.W. 1965. Summer movements of adult Leopard Frogs, Rana pipiens Schreber, in Northern Michigan. Ecology 46(3): 236-255. 
Dole, J.W. 1971. Dispersal of recently metamorphosed Leopard Frogs, Rana pipiens. Copeia 1971: 221-228.

Environmental System Research Institute. 1999. ArcView GIS version 3.2. Environmental System Research Institution, Redland, CA.

Fahrig, L. 2001. How much habitat is enough? Conservation Biology 100: 65-74.

Fahrig, L., J.H. Pedlar, S.F. Pope, P.D. Taylor, and J.F. Wegner. 1995. Effect of road traffic on amphibian density. Biological Conservation 73 (3): 177-182.

Findlay, C.S. and J. Bourdages. 2000. Response time of wetlands biodiversity to road construction. Conservation Biology 14: 86-94.

Findlay, C.S. and J. Houlahan. 1997. Anthropogenic correlates of species richness in southeastern Ontario wetlands. Conservation Biology 11(4): 1000-1009

Findlay, C.S., J. Lenton, and L. Zheng. 2001. Land-use correlates of anuran community richness and composition in southeastern Ontario wetlands. ÉCOSCIENCE 8(3): 336343.

Forman, R.T.T. and R.D. Deblinger. 2000. The ecological road-effect zone of a Massachusetts (U.S.A.) suburban highway. Conservation Biology 14(1): 36-46:

Freda, J. and W.A. Dunson. 1985. Field and laboratory studies of ion balance and growth rates of ranid tadpoles chronically exposed to low pH. Copeia 1985 (2): 415-423.

Gibbs, J. 1998. Amphibian movements in response to forest edges, roads, and streambeds in southern New England. Journal of Wildlife Management 62: 584-589.

Gosner, K.L. and I.H. Black. 1957. The effects of acidity on the development and hatching of New Jersey frogs. Ecology 38(2): 256-262.

Government of Canada, Natural Resources Canada, Earth Sciences Sector, Geomatics Canada, Centre for Topographic Information [computer file]. 2003. National Road Network, Canada, Level 1. Government of Canada, Natural Resources Canada, Centre for Topographic Information: Sherbrooke, Quebec, Canada.

Government of Canada. 1991. The Federal Policy on Wetland Conservation. Minister of Supplies and Services Canada, Ottawa, Ontario.

Green, D.M. 2003. The ecology of extinction: population fluctuation and decline in amphibians. Biological Conservation 111: 331-343. 
Guerry, A.D. and M.L. Hunter Jr. 2002. Amphibian distributions in a landscape of forests and agriculture: An examination of landscape composition and configuration.

Conservation Biology 16 (3): 745-754.

Harding, J.H. 1997. Amphibians and Reptiles of the Great Lakes Region. The University of Michigan Press, Ann Arbor.

Hecnar, S.J. and D.R. Hecnar. 1999. Pseudacris triseriata (Western chorus frog) reproduction. Herpetological Review 30: 38.

Hecnar, S.J. and R.T. M'Closkey. 1997. The effects of predatory fish on amphibian species richness and distribution. Biological Conservation 79 (2-3): 123-131.

Hecnar S. J. and R.T. M'Closkey. 1998. Species richness patterns of amphibians in southwestern Ontario ponds. Journal of Biogeography 25: 763-772.

Hels, T. and E. Buchwald. 2001. The effect of road kills on amphibian populations. Biological Conservation 99: 331-340.

Herrmann, H.L., K.J. Babbitt, M.J. Baber, and R.G. Congalton. 2005. Effects of landscape characteristics on amphibian distribution in forest-dominated landscape. Biological Conservation 123: 139-149.

Holland, J.D., D.G. Bert, and L. Fahrig. 2004. Determining the spatial scale of species' response to habitat. BioScience 54(3): 227-233.

Holland, J.D., L. Fahrig, and N. Cappuccino. 2005. Body size affects the spatial scale of habitat - beetle interactions. OIKOS 110: 101-108.

Homan, R.N., B.Y. Windmiller, and J.M. Reed. 2004. Critical thresholds associated with habitat loss for two vernal pool-breeding amphibians. Ecological Applications 14(5): 1547-1553.

Houlahan, J.E. and C.S. Findlay. 2003. The effects of adjacent land use on wetland amphibian species richness and community composition. Canadian Journal of Fisheries and Aquatic Science 60: 1078-1094.

Houlahan, J.E., C.S. Findlay, B.R. Schmidt, A.H. Meyer and S.L. Kuzmin. 2000.

Quantitative evidence for global amphibian declines. Nature 404: 752 - 755.

Knutson, M.G., W.B. Richardson, D.M. Reineke, B.R. Gray, J.R. Parmelee, and S.E. Weick. 2004. Agricultural ponds support amphibian populations. Ecological Applications 14(3): 669-684. 
Knutson, M., J. Sauer, D. Olsen, M. Mossman, L. Hemesath, and M. Lannoo. 1999. Effects of Landscape Composition and Wetland Fragmentation on Frogs and Toad Abundance and Species Richness in Iowa and Wisconsin, U.S.A. Conservation Biology 13(6): 1437-1446.

Kramer, D.C. 1973. Movements of Western Chorus Frogs Pseudacris triseriata triseriata tagged with Co 60. Journal of Herpetology 7(3): 231-235.

Laan, R. and B. Verboom. 1990. Effects of Pool Size and Isolation on Amphibian Communities. Biological Conservation 54: 251-262.

Lamoureux, V.S. and D. M. Madison. 1999. Overwintering habitats of radio-implanted Green Frogs, Rana clamitans. Journal of Herpetology 33(3): 430-435.

Lehtinen, R.M., S.M. Galatowitsch, and J.R. Tester. 1999. Consequences of habitat loss and fragmentation for wetland amphibian assemblages. Wetlands 19(1): 1-12

Lepage, M., R. Courtois, C. Daigle, and S. Matte. 1997. Chapter 14: Surveying calling anurans in Quebec using volunteers. In: Green, D. (Ed.), Amphibians in Decline: Canadian Studies of a Global Problem. Society for the Study of Amphibians \& Reptiles, pp. 130-138.

Lynch-Stewart, P. 1983. Land use change on wetlands in Southern Canada. Ontario Lands Directorate, Environment Canada, Ottawa, Working Paper No. 26.

MacCulloch, R.D. 2002. The ROM field guide to amphibians and reptiles of Ontario. Royal Ontario Museum and McClelland \& Stewart Ltd., Toronto.

Marsh, D.M., E.H. Fegraus, and S. Harrison. 1999. Effects of breeding pond isolation on the spatial and temporal dynamics of pond use by tungara frog, Physalaemus pustulosus. Journal of Animal Ecology 68(4): 804-814.

Marsh, D.M. and P.C. Trenham. 2001. Metapopulation Dynamics and Amphibian Conservation. Conservation Biology 15(1): 40-49.

Maunder, J.E. 1983. Amphibians of the province of Newfoundland. The Canadian FieldNaturalist 97: 33-46.

McGarigal, K. and W.C. McComb. 1995. Relationships between landscape structure and breeding birds in the Oregon coast range. Ecological Monographs 65(3): 235-260.

Merrell, D.J. 1970. Migration and gene dispersal in Rana pipiens. American Zoologist 10: $47-52$.

National Topographic Data Base (3rd Edition) [computer file]. Ministry of Natural Resources Canada Centre for Topographic Information (1998). 
Oldham, R.S. 1966. Spring movements in the American Toad, Bufo americanus. Journal of Zoology 44: 63-100.

Oldham, R.S. 1967. Orientating mechanisms of the Green Frog, Rana Clamitans. Ecology 48(3): 477-491.

Ontario Ministry of Natural Resources. 1999. Natural Heritage Reference Manual for Policy 2.3 of the Provincial Policy Statement. Lands and Natural Heritage Branch. Peterborough, Ontario

Pechmann, J.H.K., R. Estes, D.E. Scott, and J.W. Gibbons. 2001. Amphibian colonization and use of ponds created for trial migration of wetland loss. Wetlands 21(1): 93-111.

Pechmann, J.H.K. and H.M. Wilbur. 1994. Putting declining amphibian populations in perspective: Natural fluctuations and human impacts. Herpetologica 50(1): 65-84.

Pellet, J., A. Guisan, and N. Perrin. 2004. A concentric analysis of the impact of urbanization on the threatened European Tree Frog in an agricultural landscape. Conservation Biology 18(6): 1599-1606.

Pierce, B.A. 1985. Acid tolerance in amphibians. BioScience 35: 239-243.

Pope, S.E. 1996. The relative roles of landscape complementation and metapopulation dynamics in the distribution and abundance of leopard frogs (Rana pipiens) in OttawaCarleton. M.Sc. thesis. Carleton University, Ottawa, Ontario.

Pope, S., L. Fahrig, and H. Merriam. 2000. Landscape complementation and metapopulation effects on leopard frog populations. Ecology 81(9): 2498-2508.

Porej, D., M. Micacchion, and T.E. Hetherington. 2004. Core terrestrial habitat for conservation of local populations of salamanders and wood frogs in agricultural landscapes. Biological Conservation 120: 399-409.

Reading, C.J., J. Loman, and T. Madsen. 1991. Breeding pond fidelity in the common toad, Bufo bufo. Journal of Zoology, London 225: 201-211.

Reid, G.K. 1987. Pond Life: A guide to common plants and animals of north American ponds and lakes. Western Publishing Company, Inc., New York.

Ricklefs, R.E. and I.J. Lovette. 1999: The roles of island area per se and habitat diversity in the species-area relationships of four Lesser Antillean faunal groups. Journal of Animal Ecology 68: 1142-1160.

Roble, S.M. 1979. Dispersal movements and plant associations of juvenile grey treefrog, Hyla versicolor LeConte. Transactions of the Kansas Academy of Science 82: 235-245. 
Roland, J. and P.D. Taylor. 1997. Insect parasitoid species respond to forest structure at different spatial scales. Nature 386: 710-713.

Rothermel, B.B. and R.D. Semlitsch. 2002. An experimental investigation of landscape resistance of forest versus old-field habitats to emigrating juvenile amphibians.

Conservation Biology 16: 1324-1332.

Rubbo, M.J. and J.M. Kiesecker. 2005. Amphibian breeding distribution in an urbanized landscape. Conservation Biology 19(2): 504-511.

Scott, N.J. and B.D. Woodward. 1997. Chapter 6: Standard techniques for inventory and monitoring 8. Surveys at breeding site. In: Green, D. (Ed.), Amphibians in Decline:

Canadian Studies of a Global Problem. Society for the Study of Amphibians \& Reptiles, pp. 118-125.

Seburn, C.N.L., D.C.Seburn and C.A. Paszowski. 1997. Chapter 7: Northern leopard frog (Rana pipiens) dispersal in relation to habitat. In: Green, D. (Ed.), Amphibians in Decline: Canadian Studies of a Global Problem. Society for the Study of Amphibians \& Reptiles, pp. 64-72.

Semlitsch, R.D. 2000. Principles for management of aquatic-breeding amphibians. Journal of Wildlife Management 64(3): 615-630.

Schroeder, E.E. 1976. Dispersal and movement of newly transformed Green Frogs, Rana clamitans. American Midland Naturalist 95(2): 471-474.

Smith, M.A. and D. M. Green. 2005. Dispersal and the metapopulation paradigm in amphibian ecology and conservation: are all amphibian populations metapopulations? Ecography 28: 110-128.

Spencer, W.A. 1964. The relationship of dispersal and migration to gene flow in the boreal chorus frog. Ph.D. Dissertation, Colorado State University, Fort Collins, Colorado.

Stebbins R. C. and N.W. Cohen. 1997. A Natural History of Amphibians. Princeton University Press.

Steffan-Dewenter, I., U. Munzenberg, C. Burger, C. Thies, and T. Tscharntke. 2002. Scale-dependent effects of landscape context on three pollinator guilds. Ecology 83(5): 1421-1432.

Stuart, S.N., J.S. Chanson, N.A. Cox, B.E. Young, A.S.L. Rodrigues, D.L. Fischman, and R.W. Waller. 2004. Status and trends of amphibian declines and extinctions worldwide. Science 306: 1783-1786.

Thies, C., I. Roschewitz, and T. Tscharntke. 2005. The landscape context of cereal aphidparasitoid interactions. Proceedings of the Royal Society of Biology 272: 203-210. 
Trombulak, S.C. and C.A. Frissell. 2000. Review of ecological effects or roads on terrestrial and aquatic communities. Conservation Biology 14(1): 18-30.

Trzcinski, M.K., L. Fahrig, G. Merriam. 1999. Independent effects of forest cover and fragmentation on the distribution of forest breeding birds. Ecological Applications 9(2): 586-593.

Vance, M.D., L. Fahrig, and C.H. Flather. 2003. Effect of reproductive rate on minimum habitat requirements of forest-breeding birds. Ecology 84(1): 2643-2653.

Vos, C.C. and J.P. Chardon. 1998. Effects of habitat fragmentation and road density on the distribution pattern of the moor frog Rana arvalis. Journal of Applied Ecology 35: 44-56.

Vos, C.C., J. Verboom, P.F.M. Opdam, and C.J.F. Ter Braak. 2001. Toward ecologically scaled landscape indices. American Naturalist 157(1): 24-41.

Weeber, R.C. and M. Vallianatos (editors). 2000. The Marsh Monitoring Program 1995 1999: Monitoring Great Lakes Wetlands and Their Amphibian and Bird Inhabitants. Published by Bird Studies Canada in cooperation with Environment Canada and U.S. Environmental Protection Agency.

Woodford, J.E. and M.W. Meyer. 2003. Impact of lakeshore development on green frog abundance. Biological Conservation 110: 277-284.

Wright, A.H. and A.A. Wright. 1949. Handbook of Frogs and Toads: of the United States and Canada, $4^{\text {th }}$ ed. Vail-Ballou Press, Inc., Binghamton, New York.

Zimmerman, B.L. 1997. Chapter 6: Standard techniques for inventory and monitoring 3. Audio strip transects. In: Green, D. (Ed.), Amphibians in Decline: Canadian Studies of a Global Problem. Society for the Study of Amphibians \& Reptiles, pp. 92-97. 
Table 1. Variation in percent forest cover quantified within $150 \mathrm{~m}$, and $250 \mathrm{~m}$ to $2000 \mathrm{~m}$ radii buffers (at $250 \mathrm{~m}$ intervals) around the study ponds using digitized 1: 50,000

National Topographic Data Base (1985-1995) maps. See Appendix A for values for each pond.

\begin{tabular}{ccc}
\hline Spatial Scale & Forest Cover Range & Average Forest Cover (mean \pm SD) \\
\hline $150 \mathrm{~m}$ & $0.00 \%$ to $100 \%$ & $42.80 \% \pm 41.83 \%$ \\
$250 \mathrm{~m}$ & $0.36 \%$ to $100 \%$ & $43.93 \% \pm 37.70 \%$ \\
$500 \mathrm{~m}$ & $2.18 \%$ to $100 \%$ & $45.37 \% \pm 33.01 \%$ \\
$750 \mathrm{~m}$ & $1.82 \%$ to $95.08 \%$ & $46.81 \% \pm 30.66 \%$ \\
$1000 \mathrm{~m}$ & $3.19 \%$ to $93.32 \%$ & $46.69 \% \pm 28.44 \%$ \\
$1250 \mathrm{~m}$ & $3.51 \%$ to $86.90 \%$ & $46.46 \% \pm 26.71 \%$ \\
$1500 \mathrm{~m}$ & $4.1 \%$ to $87.90 \%$ & $46.29 \% \pm 25.69 \%$ \\
$1750 \mathrm{~m}$ & $4.04 \%$ to $86.3 \%$ & $46.49 \% \pm 24.73 \%$ \\
$2000 \mathrm{~m}$ & $4.46 \%$ to $84.48 \%$ & $47.03 \% \pm 23.69 \%$ \\
\hline
\end{tabular}

Table 2. Variation in paved road density quantified within $150 \mathrm{~m}$, and $250 \mathrm{~m}$ to $2000 \mathrm{~m}$ radii buffers (at $250 \mathrm{~m}$ intervals) around the study ponds using digitized 1: 50,000 National Road Network, Canada, Level 1 (2002) maps. See Appendix A for values for each pond.

\begin{tabular}{ccc}
\hline Spatial Scale & Paved Road Density Range & $\begin{array}{c}\text { Average Paved Road Density } \\
\text { (mean } \pm \text { SD) }\end{array}$ \\
\hline $150 \mathrm{~m}$ & $0.0 \mathrm{~m} / \mathrm{km}^{2}$ to $5030.7 \mathrm{~m} / \mathrm{km}^{2}$ & $1190.5 \mathrm{~m} / \mathrm{km}^{2} \pm 1670.7 \mathrm{~m} / \mathrm{km}^{2}$ \\
$250 \mathrm{~m}$ & $0.0 \mathrm{~m} / \mathrm{km}^{2}$ to $3288.6 \mathrm{~m} / \mathrm{km}^{2}$ & $933.2 \mathrm{~m} / \mathrm{km}^{2} \pm 1136.9 \mathrm{~m} / \mathrm{km}^{2}$ \\
$500 \mathrm{~m}$ & $0.0 \mathrm{~m} / \mathrm{km}^{2}$ to $3162.5 \mathrm{~m} / \mathrm{km}^{2}$ & $700.3 \mathrm{~m} / \mathrm{km}^{2} \pm 839.8 \mathrm{~m} / \mathrm{km}^{2}$ \\
$750 \mathrm{~m}$ & $0.0 \mathrm{~m} / \mathrm{km}^{2}$ to $3900.0 \mathrm{~m} / \mathrm{km}^{2}$ & $688.0 \mathrm{~m} / \mathrm{km}^{2} \pm 876.7 \mathrm{~m} / \mathrm{km}^{2}$ \\
$1000 \mathrm{~m}$ & $0.0 \mathrm{~m} / \mathrm{km}^{2}$ to $3125.4 \mathrm{~m} / \mathrm{km}^{2}$ & $633.3 \mathrm{~m} / \mathrm{km}^{2} \pm 719.8 \mathrm{~m} / \mathrm{km}^{2}$ \\
$1250 \mathrm{~m}$ & $0.0 \mathrm{~m} / \mathrm{km}^{2}$ to $2707.8 \mathrm{~m} / \mathrm{km}^{2}$ & $604.7 \mathrm{~m} / \mathrm{km}^{2} \pm 607.5 \mathrm{~m} / \mathrm{km}^{2}$ \\
$1500 \mathrm{~m}$ & $0.0 \mathrm{~m} / \mathrm{km}^{2}$ to $2569.5 \mathrm{~m} / \mathrm{km}^{2}$ & $606.4 \mathrm{~m} / \mathrm{km}^{2} \pm 538.2 \mathrm{~m} / \mathrm{km}^{2}$ \\
$1750 \mathrm{~m}$ & $0.0 \mathrm{~m} / \mathrm{km}^{2}$ to $2410.9 \mathrm{~m} / \mathrm{km}^{2}$ & $616.4 \mathrm{~m} / \mathrm{km}^{2} \pm 508.0 \mathrm{~m} / \mathrm{km}^{2}$ \\
$2000 \mathrm{~m}$ & $0.0 \mathrm{~m} / \mathrm{km}^{2}$ to $2191.5 \mathrm{~m} / \mathrm{km}^{2}$ & $645.3 \mathrm{~m} / \mathrm{km}^{2} \pm 503.0 \mathrm{~m} / \mathrm{km}^{2}$ \\
\hline
\end{tabular}


Table 3. Pearson correlations between percent forest cover and paved road density $\left(\mathrm{m} / \mathrm{km}^{2}\right)$ at $150 \mathrm{~m}$, and $250 \mathrm{~m}$ to $2000 \mathrm{~m}$ radii buffers (at $250 \mathrm{~m}$ intervals) around the study ponds $(\mathrm{n}=34)$.

\begin{tabular}{ccc}
\hline Scale & Correlation $(\boldsymbol{r})$ & p-value \\
\hline $150 \mathrm{~m}$ & -0.338 & 0.050 \\
$250 \mathrm{~m}$ & -0.296 & 0.089 \\
$500 \mathrm{~m}$ & -0.200 & 0.256 \\
$750 \mathrm{~m}$ & -0.137 & 0.441 \\
$1000 \mathrm{~m}$ & -0.104 & 0.558 \\
$1250 \mathrm{~m}$ & -0.127 & 0.473 \\
$1500 \mathrm{~m}$ & -0.228 & 0.195 \\
$1750 \mathrm{~m}$ & -0.250 & 0.155 \\
$2000 \mathrm{~m}$ & -0.222 & 0.207 \\
\hline
\end{tabular}


Table 4. $X^{2}$ values associated with the effect of landscape structure (forest cover (F) plus paved road density (R)) from separate models at each scale for each species using multiple multinomial logistic regression analyses. Other variables included in the models were average pond $\mathrm{pH}$, pond perimeter, and percent vegetation cover of shore plants. Bolded values indicate the spatial scale at which the relationship was the strongest.

\begin{tabular}{|c|c|c|c|c|c|c|c|c|c|c|c|c|c|c|c|}
\hline \multirow{3}{*}{$\begin{array}{l}\text { Spatial } \\
\text { Scale }\end{array}$} & \multirow{3}{*}{$\begin{array}{l}\text { Landscape } \\
\text { feature }\end{array}$} & \multicolumn{14}{|c|}{ Landscape Structures } \\
\hline & & \multicolumn{2}{|c|}{ American Toad } & \multicolumn{2}{|c|}{ Green Frog } & \multicolumn{2}{|c|}{ Gray Treefrog } & \multicolumn{2}{|c|}{ Spring Peeper } & \multicolumn{2}{|c|}{ Wood Frog } & \multicolumn{2}{|c|}{$\begin{array}{c}\text { Northern } \\
\text { Leopard Frog }\end{array}$} & \multicolumn{2}{|c|}{$\begin{array}{c}\text { Western } \\
\text { Chorus Frog }\end{array}$} \\
\hline & & $\mathbf{X}^{2}$ & $\mathbf{X}_{(\mathrm{F}+\mathrm{R})}$ & $\mathrm{X}^{2}$ & $\mathrm{X}_{(\mathrm{F}+\mathrm{R})}^{2}$ & $\mathrm{X}^{2}$ & $\mathbf{X}^{2}(\mathrm{~F}+\mathrm{R})$ & $\mathbf{X}^{2}$ & $\mathrm{X}_{(\mathrm{F}+\mathrm{R})}^{2}$ & $\mathrm{X}^{2}$ & $\mathbf{X}_{(\mathrm{F}+\mathrm{R})}$ & $\mathrm{X}^{2}$ & $\mathrm{X}_{(\mathrm{F}+\mathrm{R})}$ & $\mathrm{X}^{2}$ & $\mathbf{X}_{(\mathrm{F}+\mathrm{R})}$ \\
\hline \multirow{2}{*}{$150 \mathrm{~m}$} & Forest & 14.216 & \multirow{2}{*}{24.516} & 0.240 & \multirow{2}{*}{0.579} & 1.006 & \multirow{2}{*}{3.960} & 7.374 & \multirow{2}{*}{8.218} & 0.006 & \multirow{2}{*}{0.894} & 10.618 & \multirow{2}{*}{19.613} & 0.274 & \multirow{2}{*}{2.004} \\
\hline & Paved Road & 10.300 & & 0.339 & & 2.954 & & 0.844 & & 0.888 & & 8.995 & & 1.730 & \\
\hline \multirow{2}{*}{$250 \mathrm{~m}$} & Forest & 14.405 & \multirow{2}{*}{23.579} & 0.353 & \multirow{2}{*}{0.982} & 1.034 & \multirow{2}{*}{4.998} & 6.900 & \multirow{2}{*}{7.337} & 0.128 & \multirow{2}{*}{0.905} & 10.597 & \multirow{2}{*}{19.967} & 0.676 & \multirow{2}{*}{2.175} \\
\hline & Paved Road & 9.174 & & 0.629 & & 3.964 & & 0.437 & & 0.777 & & 9.370 & & 1.499 & \\
\hline \multirow{2}{*}{$500 \mathrm{~m}$} & Forest & 14.888 & \multirow{2}{*}{24.829} & 0.292 & \multirow{2}{*}{1.138} & 1.818 & \multirow{2}{*}{7.206} & 10.103 & \multirow{2}{*}{11.414} & 0.435 & 004 & 2.620 & 100 & 0.809 & 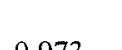 \\
\hline & Paved Road & 9.941 & & 0.846 & & 5.388 & & 1.311 & & 0.509 & 0.944 & 1.569 & 4.107 & 0.164 & $0.57 J$ \\
\hline & Forest & 7.118 & & 0.120 & & 1.125 & & 11.772 & & 0.285 & & 4.889 & & 1.416 & \\
\hline $150 \mathrm{~m}$ & Paved Road & 5.100 & 12.218 & 0.692 & 0.812 & 8.021 & 9.140 & 4.436 & 16.208 & 0.133 & 0.418 & 2.244 & 7.133 & 0.339 & 1.155 \\
\hline & Forest & 7.054 & & 0.067 & & 0.498 & & 12.740 & & 0.206 & ᄀ 100 & 6.234 & 00 & 2.178 & 202 \\
\hline 1000111 & Paved Road & 7.165 & 14.217 & 0.819 & 0.000 & 6.792 & 1.270 & 4.301 & 11.041 & 0.192 & ס & 2.606 & 0.070 & 0.648 & 2.020 \\
\hline & Forest & 7.450 & & 0 & & 0.386 & & 12.647 & & 0.158 & & 5.902 & & 3.153 & 97 \\
\hline 1200111 & Paved Road & 7.295 & 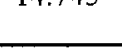 & 0.470 & 0.710 & 5.103 & 0.403 & 5.339 & 11.500 & 0.503 & 0.001 & 9.088 & 14.280 & 0.474 & 3.061 \\
\hline $1500 \mathrm{~m}$ & Forest & 10.799 & 0050 & 0.032 & 0600 & 0.528 & 5525 & 24.247 & 12726 & 0.132 & 0832 & 6.151 & 15104 & 4.203 & 4527 \\
\hline $1500 \mathrm{~min}$ & Paved Road & 9.259 & 20.050 & 0.577 & 0.009 & 5.007 & 5.350 & 19.029 & 43.210 & 0.701 & 0.833 & 9.043 & 15.194 & .0 .324 & 4.021 \\
\hline & Forest & 9.292 & & 0.194 & 0000 & 0.719 & 6814 & 17.956 & 32032 & 0.024 & 0070 & 12.677 & 21024 & 5.180 & 5320 \\
\hline $1750 \mathrm{~m}$ & Paved Road & 4.792 & 14.084 & 0.706 & 0.900 & 6.125 & 6.844 & 14.977 & 32.933 & 0.955 & 0.979 & 9.157 & 21.834 & 0.150 & 5.300 \\
\hline & Forest & 8.374 & & 0.466 & & 0.866 & 605 & 15.488 & (1907 & 0 & 021 & 13.404 & $x=40$ & 5.987 & $=000$ \\
\hline $2000 \mathrm{~m}$ & Paved Road & 2.271 & 10.043 & 1.246 & 1.112 & 5.989 & 0.050 & 14.439 & 28.821 & 0.310 & 0.010 & 10.145 & 25.047 & 0.003 & ס \\
\hline
\end{tabular}


Table 5. Weights used in the weighted Pearson correlation between the scale of strongest response to landscape structure and average dispersal distance from the literature for each species. To calculate the weights, the values in the other two columns (number of individuals and difference in $\mathbf{X}^{2}$ (see Methods)) were standardized. These were then averaged for each species. 0.99 was added to all weights to produce all non-negative values.

\begin{tabular}{r|ccc}
\hline \multicolumn{1}{c|}{ Species } & $\begin{array}{c}\text { Number of } \\
\text { individuals }\end{array}$ & $\begin{array}{c}\text { Difference } \\
\text { in } \mathbf{X}^{2}\end{array}$ & Weight \\
\hline American Toad & 72 & $14: 184$ & 0.96 \\
Green Frog & 187 & 1.242 & 0.12 \\
Gray Treefrog & 33 & 5.186 & 0.20 \\
Spring Peeper & 3 & 35.939 & 2.57 \\
Wood Frog & 138 & 0.669 & 0.00 \\
Northern Leopard Frog & 974 & 19.36 & 2.71 \\
Western Chorus Frog & 172 & 5.017 & 0.39 \\
\hline
\end{tabular}

Table 6. Weighted values for Pearson correlation between strongest percent forest cover spatial scale and average dispersal distance from the literature for each species. To calculate the weights, the values in the other two columns (number of individuals and difference in $\mathbf{X}^{2}$ (see Methods)) were standardized. These were then averaged for each species. 0.76 was added to all weights to produce all non-negative values.

\begin{tabular}{r|ccc}
\hline \multicolumn{1}{c|}{ Species } & $\begin{array}{c}\text { Number of } \\
\text { individuals }\end{array}$ & $\begin{array}{c}\text { Difference } \\
\text { in } \mathrm{X}^{2}\end{array}$ & Weight \\
\hline American Toad & 72 & 6.826 & 0.18 \\
Green Frog & 187 & 0.989 & 0.08 \\
Gray Treefrog & 33 & 5.451 & 0.05 \\
Spring Peeper & 3 & 62.305 & 2.63 \\
Wood Frog & 138 & 0.903 & 0.00 \\
Northern Leopard Frog & 974 & 15.817 & 1.93 \\
Western Chorus Frog & 172 & 9.404 & 0.44 \\
\hline
\end{tabular}


Table 7. Weighted values for Pearson correlation between strongest paved road density spatial scale and average dispersal distance from the literature for each species. To calculate the weights, the values in the other two columns (number of individuals and difference in $\mathbf{X}^{2}$ (see Methods)) were standardized. These were then averaged for each species. 0.90 was added to all weights to produce all non-negative values.

\begin{tabular}{r|ccc}
\hline \multicolumn{1}{c|}{ Species } & $\begin{array}{c}\text { Number of } \\
\text { individuals }\end{array}$ & $\begin{array}{c}\text { Difference } \\
\text { in } \mathbf{X}^{\mathbf{2}}\end{array}$ & Weight \\
\hline American Toad & 72 & 15.884 & 0.61 \\
Green Frog & 187 & 0.703 & 0.17 \\
Gray Treefrog & 33 & 2.149 & 0.00 \\
Spring Peeper & 3 & 70.741 & 2.73 \\
Wood Frog & 138 & 0.384 & 0.08 \\
Northern Leopard Frog & 974 & 17.747 & 2.03 \\
Western Chorus Frog & 172 & 13.39 & 0.66 \\
\hline
\end{tabular}


Table 8. Multiple multinomial logistic regression parameter estimates and associated Wald $\mathrm{X}^{2}$ value of anuran abundance (Index $0,1,2$, and 3 ) on percent forest cover (FOREST) and paved road density (PAVED) at the single scale at which each species had the strongest relationship to landscape structure (refer to Table 4). All predictor variables were standardized. The reference category for the equation is Index 0 , so the header "Index 1" indicates the odds of Index 1 relative to Index 0 , "Index 2 " indicates the odds of Index 2 relative to Index 0 , and "Index 3 " indicates the odds of Index 3 relative to Index 0 . For Green Frog the reference category was Index 1, because there were no 0 index values, i.e., Green Frogs were present at all ponds. Local variables included in the analyses were average pond $\mathrm{pH}(\mathrm{pH})$, pond perimeter (PERIM), and percent vegetation cover of shore plants (surface vegetation (SURF.V), emergent vegetation (EMERG.V), submerged vegetation (SUBM.V), and open water (OPEN.V)). ${ }^{*}$ p-value $<0.05$; ${ }^{*}<$ $0.01 ; * * *<0.001$.

\begin{tabular}{|c|c|c|c|c|c|}
\hline \multirow{2}{*}{ Species } & \multirow{2}{*}{$\begin{array}{c}\text { Independent } \\
\text { Variables }\end{array}$} & \multicolumn{3}{|c|}{ Dependent Variables $(\beta$ (Wald)) } & \multirow{2}{*}{$\begin{array}{l}\text { Total } \\
\text { Wald }\end{array}$} \\
\hline & & Index 1 & Index 2 & Index 3 & \\
\hline \multirow{6}{*}{ 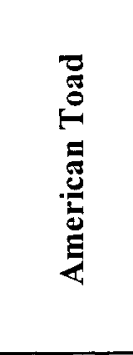 } & FOREST500 & $-0.593(1.063)^{* *}$ & $-1605.817(0.036)^{* *}$ & $-1.265(1.008)^{* *}$ & 2.107 \\
\hline & PAVED500 & $0.672(1.955)^{*}$ & $-1180.084(0.007)^{*}$ & $0.471(0.219)^{*}$ & 2.181 \\
\hline & $\mathrm{pH}$ & $2.687(1.460)^{*}$ & $-2502.580^{*}$ & $4.024(0.171)^{*}$ & 1.631 \\
\hline & PERIM & $1.258(1.839)^{* *}$ & $321.434(0.001)^{* *}$ & $2.474(4.113)^{* *}$ & 5.953 \\
\hline & OPEN.V & $0.940(1.625)^{* *}$ & $891.235(0.020)^{* *}$ & $1.286(1.008)^{* *}$ & 2.653 \\
\hline & Intercept & $0.623(0.957)^{* * *}$ & $-1785.539(0.023)^{* * *}$ & $-1.606(1.738)^{* * *}$ & 2.718 \\
\hline \multirow{6}{*}{ } & FOREST 2000 & - & $-0.324(0.452)$ & - & 0.452 \\
\hline & PAVED2000 & - & $-0.521(1.083)$ & - & 1.083 \\
\hline & $\mathrm{pH}$ & - & $-1.588(1.014)$ & - & 1.014 \\
\hline & PERIM & - & $-1.578(1.636)$ & - & 1.636 \\
\hline & OPEN.V & - & $0.256(0.226)$ & - & 0.226 \\
\hline & Intercept & - & $-1.571(5.721)^{* *}$ & - & 5.721 \\
\hline \multirow{6}{*}{ 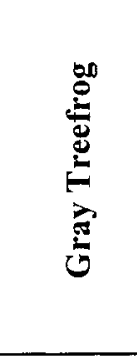 } & FOREST750 & $-0.074(0.016)$ & $-0.508(0.544)$ & $-0.717(0.697)$ & 1.257 \\
\hline & PAVED750 & $-0.151(0.099)^{*}$ & $-0.888(1.396)^{*}$ & $-3.761(3.756)^{*}$ & 5.251 \\
\hline & $\mathrm{pH}$ & $-2.075(1.100)$ & $0.336(0.036)$ & $-1.062(0.159)$ & 1.295 \\
\hline & PERIM & $-0.181(0.130)$ & $-0.819(0.658)$ & $0.303(0.136)$ & 0.944 \\
\hline & SURF.V & $0.803(1.855)^{*}$ & $-0.161(0.057)^{*}$ & $-1.997(1.757)^{*}$ & 3.669 \\
\hline & Intercept & $0.462(0.586)$ & $0.083(0.015)$ & $-2.090(1.754)$ & 2.355 \\
\hline \multirow{6}{*}{ 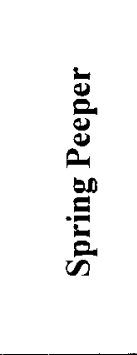 } & FOREST1500 & $-443.501(0.0)^{* * *}$ & $-3.183(1.305)^{* * *}$ & $10.648(1.167)^{* * *}$ & 2.472 \\
\hline & PAVED1500 & $369.542(0.0)^{* * *}$ & $-0.791(0.080)^{* * *}$ & $7.905(0.851)^{* * *}$ & 0.931 \\
\hline & $\mathrm{pH}$ & $169.455^{*}$ & $-2.943(0.486)^{*}$ & $-6.914(1.183)^{*}$ & 1.669 \\
\hline & PERIM & $440.901(0.0)^{* *}$ & $4.961(0.510)^{* *}$ & $-0.882(0.015)^{* *}$ & 0.525 \\
\hline & OPEN.V & $429.839(0.0)^{* * *}$ & $-0.246(0.019)^{* * *}$ & $-7.372(1.323)^{* * *}$ & 1.342 \\
\hline & Intercept & $-835.027(0.0)^{* * *}$ & $1.345(0.093)^{* * *}$ & $12.034(1.578)^{* * *}$ & 1.671 \\
\hline
\end{tabular}


Table 8. Continued.

\begin{tabular}{|c|c|c|c|c|c|}
\hline \multirow{2}{*}{ Species } & \multirow{2}{*}{$\begin{array}{c}\text { Independent } \\
\text { Variables }\end{array}$} & \multicolumn{3}{|c|}{ Dependent Variables ( $\beta$ (Wald)) } & \multirow{2}{*}{$\begin{array}{l}\text { Total } \\
\text { Wald }\end{array}$} \\
\hline & & Index 1 & Index 2 & Index 3 & \\
\hline \multirow{6}{*}{ 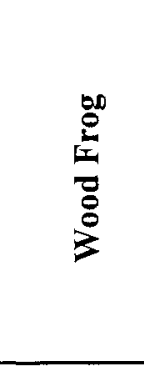 } & FOREST 1750 & $0.077(0.024)$ & $48.642(0.0)$ & $55.636(0.0)$ & 0.024 \\
\hline & PAVED1750 & $0.474(0.838)$ & $-21.812(0.0)$ & $-22.428(0.0)$ & 0.838 \\
\hline & $\mathrm{pH}$ & $-2.751(1.783)$ & -26.656 & $-136.586(0.0)$ & 1.783 \\
\hline & PERIM & $2.057(2.317)$ & $-22.367(0.0)$ & $6.074(0.0)$ & 2.317 \\
\hline & SURF.V & $0.368(0.458)$ & $18.910(0.0)$ & $-17.510(0.0)$ & 0.458 \\
\hline & Intercept & $0.991(1.710)^{* * *}$ & $-94.601(0.0)^{* * *}$ & $-127.935(0.0)^{* * *}$ & 1.710 \\
\hline \multirow{6}{*}{ 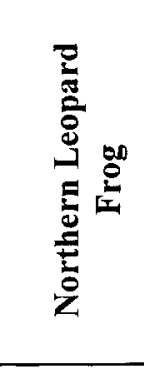 } & FOREST2000 & $-1.372(4.901)^{* *}$ & $642.359(0.0)^{* *}$ & - & 4.901 \\
\hline & PAVED2000 & $-0.577(1.355)^{* *}$ & $-2093.362(0.001)^{* *}$ & - & 1.356 \\
\hline & $\mathrm{pH}$ & $-4.013(4.720)^{* *}$ & $3325.105^{* *}$ & - & 4.720 \\
\hline & PERIM & $-0.021(0.001)$ & 26.706 & - & 0.001 \\
\hline & OPEN.V & $-0.228(0.097)$ & $522.452(0.0)$ & - & 0.097 \\
\hline & Intercept & $0.817(2.580)^{* * *}$ & $-2642.973(0.002)^{* * *}$ & - & 2.582 \\
\hline \multirow{6}{*}{ 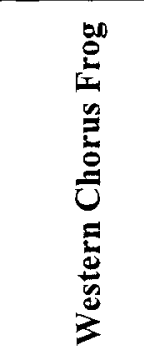 } & FOREST2000 & $1.754(3.276)^{*}$ & - & - & 3.276 \\
\hline & PAVED2000 & $-0.037(0.003)$ & - & - & 0.003 \\
\hline & $\mathrm{pH}$ & $2.986(1.535)$ & - & - & 1.535 \\
\hline & PERIM & $-0.409(0.208)$ & - & - & 0.208 \\
\hline & OPEN.V & $-0.591(0.950)$ & - & - & 0.950 \\
\hline & Intercept & $-2.305(7.360)^{* * *}$ & - & - & 7.360 \\
\hline
\end{tabular}


Table 9. $\mathrm{X}^{2}$ value associated with the effect of forest cover $(\mathrm{F})$ and paved road density $(\mathrm{R})$ at independent scales. The primary landscape feature (either forest or paved road) and scale used in the analyses was the one that had the strongest relationship in Question 1. Analyses were performed for each anuran using multiple multinomial logistic regression. Other variables included in the analyses were average pond $\mathrm{pH}$, pond perimeter, and percent vegetation cover of shore plants. Bolded values indicate the spatial scales at which the relationship was the strongest.

a) American Toad:

$\%$ Forest Cover at $500 \mathrm{~m}$ scale

\begin{tabular}{|c|c|c|c|}
\hline $\begin{array}{l}\text { Spatial } \\
\text { Scales }\end{array}$ & $\begin{array}{l}\text { Landscape } \\
\text { Feature }\end{array}$ & $\begin{array}{c}\mathbf{X}^{2} \text { values of } \\
\text { Landscape Feature }\end{array}$ & $\begin{array}{l}\text { Sum of } X_{(F+R)}^{2} \text { values } \\
\text { for forest cover and } \\
\text { paved road density }\end{array}$ \\
\hline $500 \mathrm{~m}$ & Forest & 10.044 & \multirow{2}{*}{24.370} \\
\hline $150 \mathrm{~m}$ & Paved Road & 14.326 & \\
\hline $500 \mathrm{~m}$ & Forest & 13.988 & \multirow{2}{*}{31.196} \\
\hline $250 \mathrm{~m}$ & Paved Road & 17.208 & \\
\hline $500 \mathrm{~m}$ & Forest & 14.888 & \multirow{2}{*}{24.829} \\
\hline $500 \mathrm{~m}$ & Paved Road & 9.941 & \\
\hline $500 \mathrm{~m}$ & Forest & 15.047 & \multirow{2}{*}{26.211} \\
\hline $750 \mathrm{~m}$ & Paved Road & 11.164 & \\
\hline $500 \mathrm{~m}$ & Forest & 14.803 & \multirow{2}{*}{27.830} \\
\hline $1000 \mathrm{~m}$ & Paved Road & 13.027 & \\
\hline $500 \mathrm{~m}$ & Forest & 13.881 & \multirow{2}{*}{26.116} \\
\hline $1250 \mathrm{~m}$ & Paved Road & 12.235 & \\
\hline $500 \mathrm{~m}$ & Forest & 13.538 & \multirow{2}{*}{25.23} \\
\hline $1500 \mathrm{~m}$ & Paved Road & 11.692 & \\
\hline $500 \mathrm{~m}$ & Forest & 14.238 & \multirow{2}{*}{24.772} \\
\hline $1750 \mathrm{~m}$ & Paved Road & 10.534 & \\
\hline $500 \mathrm{~m}$ & Forest & 15,094 & \multirow{2}{*}{24.712} \\
\hline $2000 \mathrm{~m}$ & Paved Road & 9.618 & \\
\hline
\end{tabular}

b) Green Frog:

Paved Road Density at $2000 \mathrm{~m}$ scale

\begin{tabular}{|c|c|c|c|}
\hline $\begin{array}{l}\text { Spatial } \\
\text { Scales }\end{array}$ & $\begin{array}{c}\text { Landscape } \\
\text { Feature }\end{array}$ & $\begin{array}{c}\mathrm{X}^{2} \text { values of } \\
\text { Landscape Feature }\end{array}$ & $\begin{array}{l}\text { Sum of } X_{(F+R)}^{2} \text { values } \\
\text { for forest cover and } \\
\text { paved road density }\end{array}$ \\
\hline $150 \mathrm{~m}$ & Forest & 0.284 & \multirow{2}{*}{1.269} \\
\hline $2000 \mathrm{~m}$ & Paved Road & 0.985 & \\
\hline $250 \mathrm{~m}$ & Forest & 0.409 & \multirow{2}{*}{1.413} \\
\hline $2000 \mathrm{~m}$ & Paved Road & 1.004 & \\
\hline $500 \mathrm{~m}$ & Forest & 0.281 & \multirow{2}{*}{1.271} \\
\hline $2000 \mathrm{~m}$ & Paved Road & 0.990 & \\
\hline $750 \mathrm{~m}$ & Forest & 0.052 & \multirow{2}{*}{1.032} \\
\hline $2000 \mathrm{~m}$ & Paved Road & 0.980 & \\
\hline $1000 \mathrm{~m}$ & Forest & 0.007 & \multirow{2}{*}{1.009} \\
\hline $2000 \mathrm{~m}$ & Paved Road & 1.002 & \\
\hline $1250 \mathrm{~m}$ & Forest & 0.018 & \multirow{2}{*}{1.075} \\
\hline $2000 \mathrm{~m}$ & Paved Road & 1.057 & \\
\hline $1500 \mathrm{~m}$ & Forest & 0.073 & \multirow{2}{*}{1.177} \\
\hline $2000 \mathrm{~m}$ & Paved Road & 1.104 & \\
\hline $1750 \mathrm{~m}$ & Forest & 0.256 & \multirow{2}{*}{1.450} \\
\hline $2000 \mathrm{~m}$ & Paved Road & 1.194 & \\
\hline $2000 \mathrm{~m}$ & Forest & 0.466 & \multirow{2}{*}{1.712} \\
\hline $2000 \mathrm{~m}$ & Paved Road & 1.246 & \\
\hline
\end{tabular}


Table 9. Continued.

c) Gray Treefrog:

Paved Road Density at $750 \mathrm{~m}$ scale

\begin{tabular}{|c|c|c|c|}
\hline $\begin{array}{l}\text { Spatial } \\
\text { Scales }\end{array}$ & $\begin{array}{l}\text { Landscape } \\
\text { Feature }\end{array}$ & $\begin{array}{c}X^{2} \text { values of } \\
\text { Landscape Feature }\end{array}$ & $\begin{array}{l}\text { Sum of } X_{(F+R)}^{2} \text { values } \\
\text { for forest cover and } \\
\text { paved road density }\end{array}$ \\
\hline $150 \mathrm{~m}$ & Forest & 1.619 & \multirow{2}{*}{9.680} \\
\hline $750 \mathrm{~m}$ & Paved Road & 8.061 & \\
\hline $250 \mathrm{~m}$ & Forest & 1.722 & \multirow{2}{*}{9.875} \\
\hline $750 \mathrm{~m}$ & Paved Road & 8.153 & \\
\hline $500 \mathrm{~m}$ & Forest & 1.683 & \multirow{2}{*}{9.935} \\
\hline $750 \mathrm{~m}$ & Paved Road & 8.252 & \\
\hline $750 \mathrm{~m}$ & Forest & 1.125 & \multirow{2}{*}{9.146} \\
\hline $750 \mathrm{~m}$ & Paved Road & 8.021 & \\
\hline $1000 \mathrm{~m}$ & Forest & 0.535 & \multirow{2}{*}{8.137} \\
\hline $750 \mathrm{~m}$ & Paved Road & 7.602 & \\
\hline $1250 \mathrm{~m}$ & Forest & 0.454 & \multirow{2}{*}{7.786} \\
\hline $750 \mathrm{~m}$ & Paved Road & 7.332 & \\
\hline $1500 \mathrm{~m}$ & Forest & 0.544 & \multirow{2}{*}{7.810} \\
\hline $750 \mathrm{~m}$ & Paved Road & 7.266 & \\
\hline $1750 \mathrm{~m}$ & Forest & 0.730 & \multirow{2}{*}{8.195} \\
\hline $750 \mathrm{~m}$ & Paved Road & 7.465 & \\
\hline $2000 \mathrm{~m}$ & Forest & 0.871 & \multirow{2}{*}{8.541} \\
\hline $750 \mathrm{~m}$ & Paved Road & 7.670 & \\
\hline
\end{tabular}

d) Spring Peeper:

$\%$ Forest Cover at $1500 \mathrm{~m}$ scale

\begin{tabular}{|c|c|c|c|}
\hline $\begin{array}{l}\text { Spatial } \\
\text { Scales }\end{array}$ & $\begin{array}{l}\text { Landscape } \\
\text { Feature }\end{array}$ & $\begin{array}{c}X^{2} \text { values of } \\
\text { Landscape Feature }\end{array}$ & $\begin{array}{l}\text { Sum of } X_{(F+R)}^{2} \text { values } \\
\text { for forest cover and } \\
\text { paved road density }\end{array}$ \\
\hline $1500 \mathrm{~m}$ & Forest & 45.641 & \multirow{2}{*}{78.959} \\
\hline $150 \mathrm{~m}$ & Paved Road & 33.318 & \\
\hline $1500 \mathrm{~m}$ & Forest & 19.923 & \multirow{2}{*}{27.476} \\
\hline $250 \mathrm{~m}$ & Paved Road & 7.553 & \\
\hline $1500 \mathrm{~m}$ & Forest & 17.231 & \multirow{2}{*}{22.957} \\
\hline $500 \mathrm{~m}$ & Paved Road & 5.726 & \\
\hline $1500 \mathrm{~m}$ & Forest & 12.982 & \multirow{2}{*}{17.058} \\
\hline $750 \mathrm{~m}$ & Paved Road & 4.076 & \\
\hline $1500 \mathrm{~m}$ & Forest & 12.758 & \multirow{2}{*}{16.654} \\
\hline $1000 \mathrm{~m}$ & Paved Road & 3.896 & \\
\hline $1500 \mathrm{~m}$ & Forest & 12.724 & \multirow{2}{*}{18.302} \\
\hline $1250 \mathrm{~m}$ & Paved Road & 5.578 & \\
\hline $1500 \mathrm{~m}$ & Forest & 24.247 & \multirow{2}{*}{43.276} \\
\hline $1500 \mathrm{~m}$ & Paved Road & 19.029 & \\
\hline $1500 \mathrm{~m}$ & Forest & 20.492 & \multirow{2}{*}{36.959} \\
\hline $1750 \mathrm{~m}$ & Paved Road & 16.467 & \\
\hline $1500 \mathrm{~m}$ & Forest & 19.537 & \multirow{2}{*}{35.692} \\
\hline $2000 \mathrm{~m}$ & Paved Road & 16.155 & \\
\hline
\end{tabular}


Table 9. Continued.

e) Wood Frog:

Paved Road Density at $1750 \mathrm{~m}$ scale

\begin{tabular}{|c|c|c|c|}
\hline $\begin{array}{l}\text { Spatial } \\
\text { Scales }\end{array}$ & $\begin{array}{l}\text { Landscape } \\
\text { Feature }\end{array}$ & $\begin{array}{c}\mathrm{X}^{2} \text { values of } \\
\text { Landscape Feature }\end{array}$ & $\begin{array}{c}\text { Sum of } \mathrm{X}_{(\mathrm{F}+\mathrm{R})}^{2} \text { values } \\
\text { for forest cover and } \\
\text { paved road density }\end{array}$ \\
\hline $150 \mathrm{~m}$ & Forest & 0.049 & \multirow{2}{*}{0.989} \\
\hline $1750 \mathrm{~m}$ & Paved Road & 0.940 & \\
\hline $250 \mathrm{~m}$ & Forest & 0.164 & \multirow{2}{*}{1.072} \\
\hline $1750 \mathrm{~m}$ & Paved Road & 0.908 & \\
\hline $500 \mathrm{~m}$ & Forest & 0.372 & \multirow{2}{*}{1.281} \\
\hline $1750 \mathrm{~m}$ & Paved Road & 0.909 & \\
\hline $750 \mathrm{~m}$ & Forest & 0.336 & \multirow{2}{*}{1.321} \\
\hline $1750 \mathrm{~m}$ & Paved Road & 0.985 & \\
\hline $1000 \mathrm{~m}$ & Forest & 0.287 & \multirow{2}{*}{1.280} \\
\hline $1750 \mathrm{~m}$ & Paved Road & 0.993 & \\
\hline $1250 \mathrm{~m}$ & Forest & 0.223 & \multirow{2}{*}{1.218} \\
\hline $1750 \mathrm{~m}$ & Paved Road & 0.995 & \\
\hline $1500 \mathrm{~m}$ & Forest & 0.150 & \multirow{2}{*}{1.146} \\
\hline $1750 \mathrm{~m}$ & Paved Road & 0.996 & \\
\hline $1750 \mathrm{~m}$ & Forest & 0.024 & \multirow{2}{*}{0.979} \\
\hline $1750 \mathrm{~m}$ & Paved Road & 0.955 & \\
\hline $2000 \mathrm{~m}$ & Forest & 0.001 & \multirow{2}{*}{0.937} \\
\hline $1750 \mathrm{~m}$ & Paved Road & 0.936 & \\
\hline
\end{tabular}

f) Northern Leopard Frog:

$\%$ Forest Cover at $2000 \mathrm{~m}$ scale

\begin{tabular}{|c|c|c|c|}
\hline $\begin{array}{l}\text { Spatial } \\
\text { Scales }\end{array}$ & $\begin{array}{l}\text { Landscape } \\
\text { Feature }\end{array}$ & $\begin{array}{c}\mathrm{X}^{2} \text { values of } \\
\text { Landscape Feature }\end{array}$ & $\begin{array}{l}\text { Sum of } X_{(F+R)}^{2} \text { values } \\
\text { for forest cover and } \\
\text { paved road density }\end{array}$ \\
\hline $2000 \mathrm{~m}$ & Forest & 6.707 & \multirow{2}{*}{7.732} \\
\hline $150 \mathrm{~m}$ & Paved Road & 1.025 & \\
\hline $2000 \mathrm{~m}$ & Forest & 7.095 & \multirow{2}{*}{8.640} \\
\hline $250 \mathrm{~m}$ & Paved Road & 1.545 & \\
\hline $2000 \mathrm{~m}$ & Forest & 6.926 & \multirow{2}{*}{8.335} \\
\hline $500 \mathrm{~m}$ & Paved Road & 1.409 & \\
\hline $2000 \mathrm{~m}$ & Forest & 13.605 & \multirow{2}{*}{22.422} \\
\hline $750 \mathrm{~m}$ & Paved Road & 8.817 & \\
\hline $2000 \mathrm{~m}$ & Forest & 13.444 & \multirow{2}{*}{22.258} \\
\hline $1000 \mathrm{~m}$ & Paved Road & 8.814 & \\
\hline $2000 \mathrm{~m}$ & Forest & 5.708 & \multirow{2}{*}{14.468} \\
\hline $1250 \mathrm{~m}$ & Paved Road & 8.760 & \\
\hline $2000 \mathrm{~m}$ & Forest & 5.729 & \multirow{2}{*}{14.512} \\
\hline $1500 \mathrm{~m}$ & Paved Road & 8.783 & \\
\hline $2000 \mathrm{~m}$ & Forest & 12.360 & \multirow{2}{*}{21,362} \\
\hline $1750 \mathrm{~m}$ & Paved Road & 9.002 & \\
\hline $2000 \mathrm{~m}$ & Forest & 13.404 & \multirow{2}{*}{23.549} \\
\hline $2000 \mathrm{~m}$ & Paved Road & 10.145 & \\
\hline
\end{tabular}


Table 9. Continued.

g) Western Chorus Frog:

$\%$ Forest Cover at $2000 \mathrm{~m}$ scale

\begin{tabular}{|c|c|c|c|}
\hline $\begin{array}{l}\text { Spatial } \\
\text { Scales }\end{array}$ & $\begin{array}{l}\text { Landscape } \\
\text { Feature }\end{array}$ & $\begin{array}{c}\mathbf{X}^{2} \text { values of } \\
\text { Landscape Feature }\end{array}$ & $\begin{array}{l}\text { Sum of } X_{(F+R)}^{2} \text { values } \\
\text { for forest cover and } \\
\text { paved road density }\end{array}$ \\
\hline $2000 \mathrm{~m}$ & Forest & 9.983 & \multirow{2}{*}{15.394} \\
\hline $150 \mathrm{~m}$ & Paved Road & 5.411 & \\
\hline $2000 \mathrm{~m}$ & Forest & 8.633 & \multirow{2}{*}{12.389} \\
\hline $250 \mathrm{~m}$ & Paved Road & 3.756 & \\
\hline $2000 \mathrm{~m}$ & Forest & 6.426 & \multirow{2}{*}{6.884} \\
\hline $500 \mathrm{~m}$ & Paved Road & 0.458 & \\
\hline $2000 \mathrm{~m}$ & Forest & 6.403 & \multirow{2}{*}{7.021} \\
\hline $750 \mathrm{~m}$ & Paved Road & 0.618 & \\
\hline $2000 \mathrm{~m}$ & Forest & 6.369 & \multirow{2}{*}{7.262} \\
\hline $1000 \mathrm{~m}$ & Paved Road & 0.893 & \\
\hline $2000 \mathrm{~m}$ & Forest & 6.554 & \multirow{2}{*}{7.346} \\
\hline $1250 \mathrm{~m}$ & Paved Road & 0.792 & \\
\hline $2000 \mathrm{~m}$ & Forest & 6.492 & \multirow{2}{*}{6.959} \\
\hline $1500 \mathrm{~m}$ & Paved Road & 0.467 & \\
\hline $2000 \mathrm{~m}$ & Forest & 6.265 & \multirow{2}{*}{6.433} \\
\hline $1750 \mathrm{~m}$ & Paved Road & 0.168 & \\
\hline $2000 \mathrm{~m}$ & Forest & 5.987 & \multirow{2}{*}{5.990} \\
\hline $2000 \mathrm{~m}$ & Paved Road & 0.003 & \\
\hline
\end{tabular}


Table 10. The difference between the largest summed $X^{2}$ value for the effects of forest cover (F) and paved road density (R) at independent scales and the largest summed $\mathrm{X}^{2}$ for the effects of forest and paved road density at the same scale, on the abundance of each species (refer to Tables 4 and 9 ). ${ }^{*}$ p-value $<0.05 ; * *<0.01 ; * * * 0.001$.

\begin{tabular}{|c|c|c|c|c|c|c|c|c|c|c|c|c|c|c|c|c|c|c|c|c|c|c|}
\hline & \multirow{2}{*}{$\begin{array}{l}\text { Landscape } \\
\text { feature }\end{array}$} & \multicolumn{3}{|c|}{ American Toad } & \multicolumn{3}{|c|}{ Green Frog } & \multicolumn{3}{|c|}{ Gray Treefrog } & \multicolumn{3}{|c|}{ Spring Pceper } & \multicolumn{3}{|c|}{ Wood Frog } & \multicolumn{3}{|c|}{$\begin{array}{c}\text { Northern Leopard } \\
\text { Frog } \\
\end{array}$} & \multicolumn{3}{|c|}{$\begin{array}{c}\text { Western Chorus } \\
\text { Frog } \\
\end{array}$} \\
\hline & & $\begin{array}{l}\text { Scale } \\
(\mathrm{m})\end{array}$ & $\mathrm{X}^{2}$ & $\begin{array}{c}X^{2} \\
(F+R)\end{array}$ & $\begin{array}{l}\text { Scale } \\
(\mathrm{m})\end{array}$ & $\mathrm{X}^{2}$ & $\begin{array}{c}X^{2} \\
(F+R)\end{array}$ & $\begin{array}{l}\text { Scale } \\
(\mathrm{m})\end{array}$ & $\mathrm{X}^{2}$ & $\begin{array}{c}\mathrm{X}^{2} \\
(\mathrm{~F}+\mathrm{R})\end{array}$ & $\begin{array}{l}\text { Scale } \\
(\mathrm{m})\end{array}$ & $\mathrm{X}^{2}$ & $\underset{(\mathbf{F}+\mathbf{R})}{\mathrm{X}^{2}}$ & $\begin{array}{l}\text { Scale } \\
(\mathrm{m})\end{array}$ & $\mathrm{X}^{2}$ & $\underset{(\mathrm{F}+\mathrm{R})}{\mathrm{X}^{2}}$ & $\begin{array}{c}\text { Scale } \\
(\mathrm{m})\end{array}$ & $\mathrm{X}^{2}$ & $\begin{array}{c}\mathbf{X}^{2} \\
(\mathrm{~F}+\mathrm{R})\end{array}$ & $\begin{array}{l}\text { Scale } \\
\text { (m) }\end{array}$ & $\mathrm{X}^{2}$ & $\underset{(F+R)}{X^{2}}$ \\
\hline \multirow{2}{*}{$\begin{array}{c}\mathbf{X}^{2}{ }_{A} \\
\text { (fforest }+ \text { paved } \\
\text { road at } \\
\text { independent } \\
\text { scaless) }\end{array}$} & Forest & 500 & 13.99 & \multirow{2}{*}{31.20} & 2000 & 0.47 & \multirow{2}{*}{1.72} & 500 & 1.68 & \multirow{2}{*}{9.93} & 1500 & 45.64 & \multirow{2}{*}{78.96} & 750 & 0.34 & \multirow{2}{*}{1.33} & 2000 & 13.40 & \multirow{2}{*}{23.55} & 2000 & 9.98 & \multirow{2}{*}{15.39} \\
\hline & Paved Road & 250 & 17.21 & & 2000 & 1.25 & & 750 & 8.25 & & 150 & 33.32 & & 1750 & 0.99 & & 2000 & 10.15 & & 150 & 5.41 & \\
\hline \multirow{2}{*}{$\begin{array}{c}\mathbf{X}^{2}{ }_{B} \\
\text { (forcst + paved } \\
\text { road at the same } \\
\text { scale) }\end{array}$} & Forest & 500 & 14.89 & \multirow{2}{*}{24.83} & 2000 & 0.47 & \multirow{2}{*}{1.72} & 750 & 1.13 & \multirow{2}{*}{9.15} & 1500 & 24.25 & \multirow{2}{*}{43.28} & 1750 & 0.02 & \multirow{2}{*}{0.98} & 2000 & 13.40 & \multirow{2}{*}{23.55} & 2000 & 5.99 & \multirow{2}{*}{5.99} \\
\hline & Paved Road & 500 & 9.94 & & 2000 & 1.25 & & 750 & 8.02 & & 1500 & 19.03 & & 1750 & 0.96 & & 2000 & 10.15 & & 2000 & 0 & \\
\hline \multicolumn{2}{|c|}{$\begin{array}{c}\text { Difference between } \\
\text { landscape } \\
\mathrm{X}_{\mathrm{A}}^{2} \text { and } \mathrm{X}^{2}{ }_{\mathrm{B}}\end{array}$} & \multicolumn{3}{|c|}{$6.37 *$} & \multicolumn{3}{|c|}{0} & & 0.78 & & \multicolumn{3}{|c|}{$35.68^{* * *}$} & \multicolumn{3}{|c|}{0.35} & \multicolumn{3}{|c|}{0} & \multicolumn{3}{|c|}{$9.40^{* *}$} \\
\hline
\end{tabular}


Table 11. Multiple multinomial logistic regression parameter estimates and associated Wald $\mathrm{X}^{2}$ value of anuran abundance (Index $0,1,2$, and 3 ) on percent forest cover (FOREST) and paved road density (PAVED) at the individual scales at which each species had the strongest relationships with each landscape feature (refer to Table 9). All predictor variables were standardized. The reference category for the equation is Index 0 , so the header "Index 1" indicates the odds of Index 1 relative to Index 0 , "Index 2" indicates the odds of Index 2 relative to Index 0 , and "Index 3 " indicates the odds of Index 3 relative to Index 0 . For Green Frog the reference category was Index 1, because there were no 0 index values, i.e., Green Frogs were present at all ponds. Local variables included in the model were average pond $\mathrm{pH}(\mathrm{pH})$, pond perimeter (PERIM), and percent vegetation cover of shore plants (surface vegetation (SURF.V), emergent vegetation (EMERG.V), submerged vegetation (SUBM.V), and open water (OPEN.V)). * p-value < $0.05 ; * *<0.01 ; * * *<0.001$.

\begin{tabular}{|c|c|c|c|c|c|}
\hline \multirow{2}{*}{ Species } & \multirow{2}{*}{$\begin{array}{c}\text { Independent } \\
\text { Variables }\end{array}$} & \multicolumn{3}{|c|}{ Dependent Variables $(\beta$ (Wald)) } & \multirow{2}{*}{$\begin{array}{l}\text { Total } \\
\text { Wald }\end{array}$} \\
\hline & & Index 1 & Index 2 & Index 3 & \\
\hline \multirow{6}{*}{ 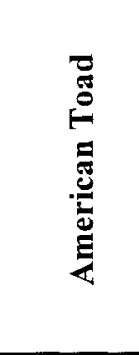 } & FOREST500 & $-0.478(0.481) * *$ & $-3841.845(0.167)^{* *}$ & $-1.159(0.806)^{* *}$ & 1.454 \\
\hline & PAVED250 & $1.779(6.004) * *$ & $-1991.697(0.026)^{* *}$ & $1.026(0.979) * *$ & 2.009 \\
\hline & $\mathrm{pH}$ & $3.411(1.242) *$ & $-5877.056^{*}$ & $4.939(1.851)^{*}$ & 3.093 \\
\hline & PERIM & $1.646(1.457) * *$ & $504.283(0.002)^{* *}$ & $2.825(3.208)^{* *}$ & 4.667 \\
\hline & OPEN.V & $1.334(1.671) * *$ & $2117.621(0.093)^{* *}$ & $1.677(1.333)^{* *}$ & 3.097 \\
\hline & Intercept & $1.070(1.314) * * *$ & $-3705.627(0.105)^{* * *}$ & $-0.941(0.500)^{* * *}$ & 1.919 \\
\hline \multirow{6}{*}{ 总 } & FOREST2000 & - & $-0.324(0.452)$ & - & 0.452 \\
\hline & PAVED2000 & - & $-0.521(1.083)$ & - & 1.083 \\
\hline & $\mathrm{pH}$ & - & $-1.588(1.014)$ & - & 1.014 \\
\hline & PERIM & - & $-1.578(1.636)$ & - & 1.636 \\
\hline & OPEN.V & - & $0.256(0.226)$ & - & 0.226 \\
\hline & Intercept & - & $-1.571(5.721) * *$ & - & 5.721 \\
\hline \multirow{6}{*}{ 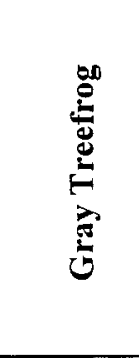 } & FOREST500 & $-0.011(0.0)$ & $-0.604(0.687)$ & $-0.806(0.913)$ & 1.600 \\
\hline & PAVED750 & $-0.141(0.085) *$ & $-0.891(1.381)^{*}$ & $-3.863(3.827)^{*}$ & 5.293 \\
\hline & $\mathrm{pH}$ & $-1.992(1.007)$ & $0.254(0.020)$ & $-1.232(0.205)$ & 1.232 \\
\hline & PERIM & $-0.186(0.140)$ & $-0.856(0.685)$ & $0.300(0.123)$ & 0.948 \\
\hline & SURF.V & $0.793(1.805) *$ & $-0.190(0.077) *$ & $-2.108(1.884) *$ & 3.766 \\
\hline & Intercept & $0.459(0.578)$ & $0.052(0.005)$ & $-2.205(1.850)$ & 2.433 \\
\hline \multirow{6}{*}{ 离 } & FOREST 1500 & $-600.702(0.001)^{* * *}$ & $-41.833(0.0) * * *$ & $3146.712(0.010) * * *$ & 0.011 \\
\hline & PAVED150 & $30.997(0.0) * * *$ & $19.418(0.0)^{* * *}$ & $1100.699(0.005) * * *$ & 0.005 \\
\hline & $\mathrm{pH}$ & $-225.621(0.0) * * *$ & $-61.233(0.0) * * *$ & $-1278.419(0.001) * * *$ & 0.001 \\
\hline & PERIM & $663.987(0.001) * * *$ & $37.876(0.0) * * *$ & $-873.082(0.002) * * *$ & 0.003 \\
\hline & OPEN.V & $-10.966(0.0)^{* * *}$ & $4.826(0.0)^{* * *}$ & $-2294.335(0.013) * * *$ & 0.013 \\
\hline & Intercept & $-397.112(0.002) * * *$ & $8.675(0.0) * * *$ & $1185.256(0.009) * * *$ & 0.011 \\
\hline
\end{tabular}


Table 11. Continued.

\begin{tabular}{|c|c|c|c|c|c|}
\hline \multirow{2}{*}{ Species } & \multirow{2}{*}{$\begin{array}{c}\text { Independent } \\
\text { Variables }\end{array}$} & \multicolumn{3}{|c|}{ Dependent Variables $(\beta$ (Wald)) } & \multirow{2}{*}{$\begin{array}{l}\text { Total } \\
\text { Wald }\end{array}$} \\
\hline & & Index 1 & Index 2 & Index 3 & \\
\hline \multirow{6}{*}{ 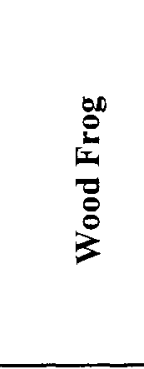 } & FOREST750 & $0.327(0.326)$ & $35.961(0.0)$ & $41.249(0.0)$ & 0.326 \\
\hline & PAVED 1750 & $0.475(0.877)$ & $-18.924(0.0)$ & $-15.275(0.0)$ & 0.877 \\
\hline & $\mathrm{pH}$ & $-2.400(1.321)$ & -90.282 & -56.343 & 1.321 \\
\hline & PERIM & $2.136(2.218)$ & $-29.127(0.0)$ & $3.378(0.0)$ & 2.218 \\
\hline & SURF.V & $0.358(0.410)$ & $21.788(0.0)$ & $-9.238(0.0)$ & 0.410 \\
\hline & Intercept & $1.096(1.785)^{* * *}$ & $-96.611(0.0)^{* * *}$ & $-82.575(0.0)^{* * *}$ & 1.785 \\
\hline \multirow{6}{*}{ 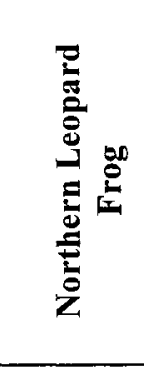 } & FOREST2000 & $-1.372(4.901)^{* *}$ & $642.359(0.0)^{* *}$ & - & 4.901 \\
\hline & PAVED2000 & $-0.577(1.355)^{* *}$ & $-2093.362(0.001)^{* *}$ & - & 1.356 \\
\hline & $\mathrm{pH}$ & $-4.013(4.720)^{* *}$ & $3325.105^{* *}$ & - & 4.720 \\
\hline & PERIM & $-0.021(0.001)$ & 26.706 & - & 0.001 \\
\hline & OPEN.V & $-0.228(0.097)$ & $522.452(0.0)$ & - & 0.097 \\
\hline & Intercept & $0.817(2.580)^{* * *}$ & $-2642.973(0.002)^{* * *}$ & - & 2.582 \\
\hline \multirow{6}{*}{ 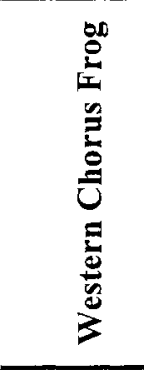 } & FOREST2000 & $2.886(3.538) * *$ & - & - & 3.538 \\
\hline & PAVED150 & $1.982(3.084)^{*}$ & - & - & 3.084 \\
\hline & $\mathrm{pH}$ & $1.325(0.257)$ & - & - & 0.257 \\
\hline & PERIM & $-0.621(0.296)$ & - & - & 0.296 \\
\hline & OPEN.V & $-1.516(1.094)$ & - & - & 1.094 \\
\hline & Intercept & $-3.447(5.146)^{* * *}$ & - & - & 5.146 \\
\hline
\end{tabular}




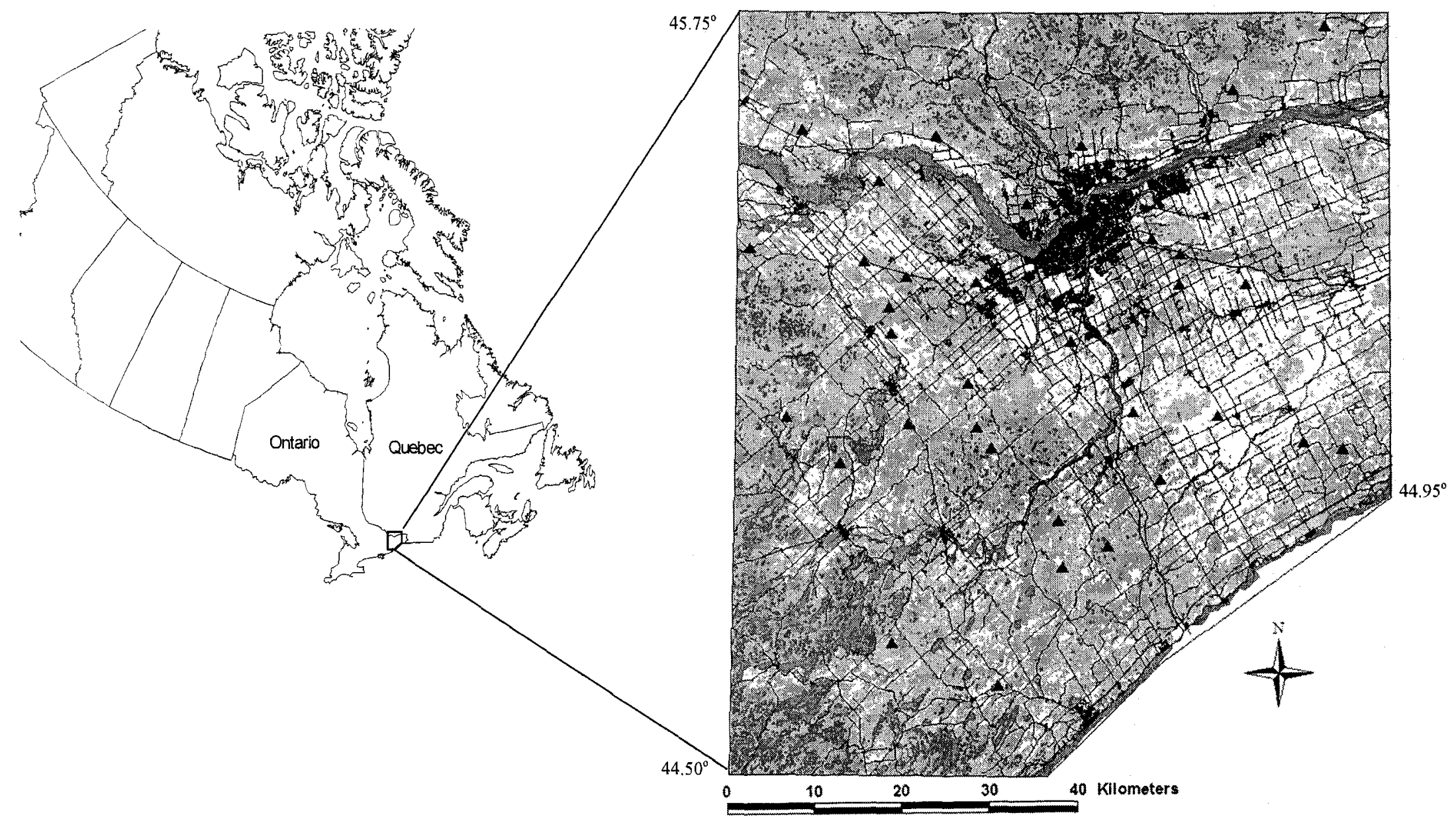

Figure 1. Study area in eastern Ontario and a small proportion of western Quebec, Canada, showing the locations of the 34 ponds (triangles). Light grey areas represent the forest, dark grey represents water, black lines represent paved roads and white areas include all other habitat types. 


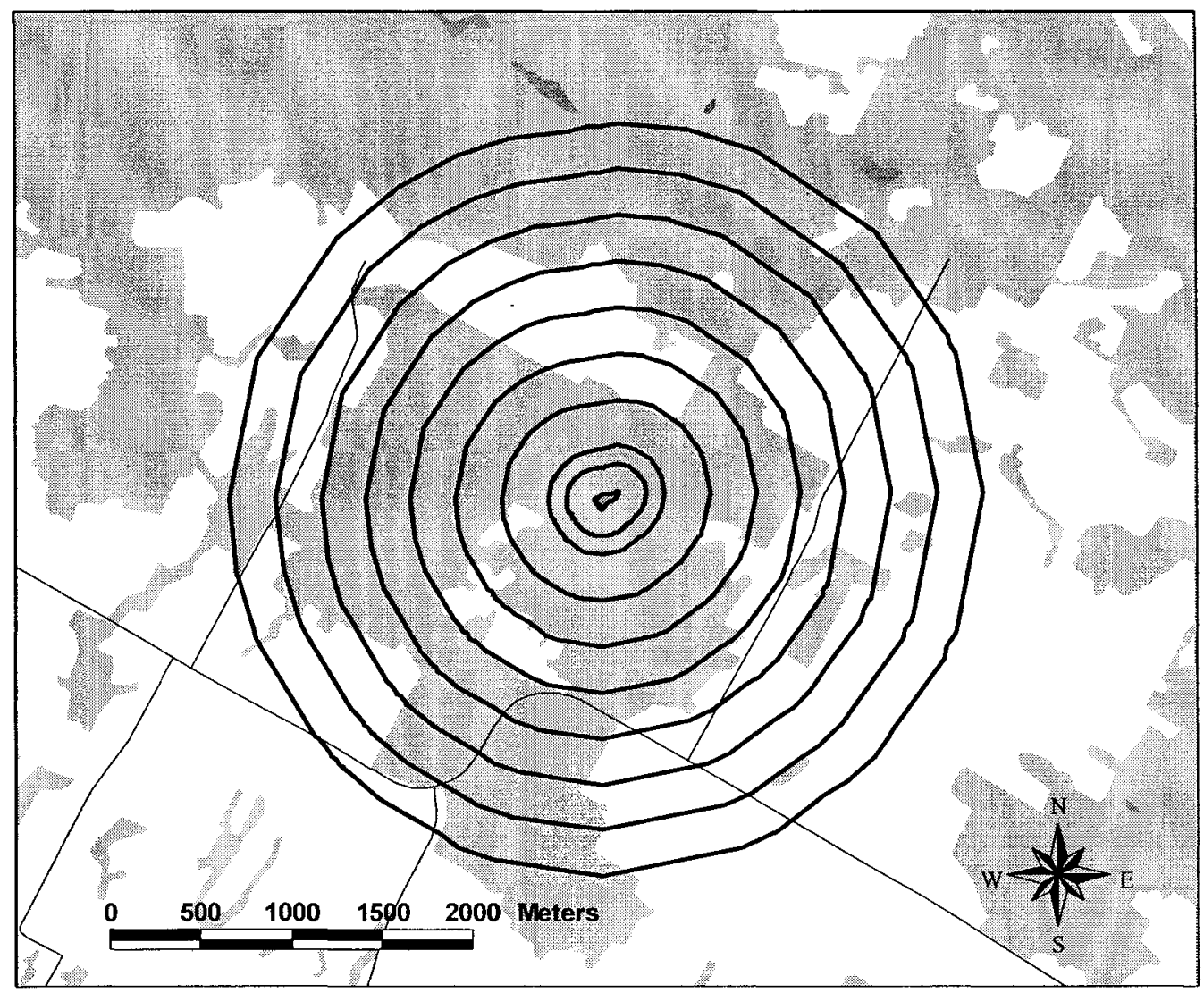

Figure 2. Example of a pond with its associated landscape context. The 150, 250, 500, $750,1000,1250,1500,1750$, and $2000 \mathrm{~m}$ radii buffers around the perimeter are indicated as thick black lines, the thin black lines represent paved roads, the light grey area represents forest, the dark grey represents water, and the white area includes all other habitat types. 


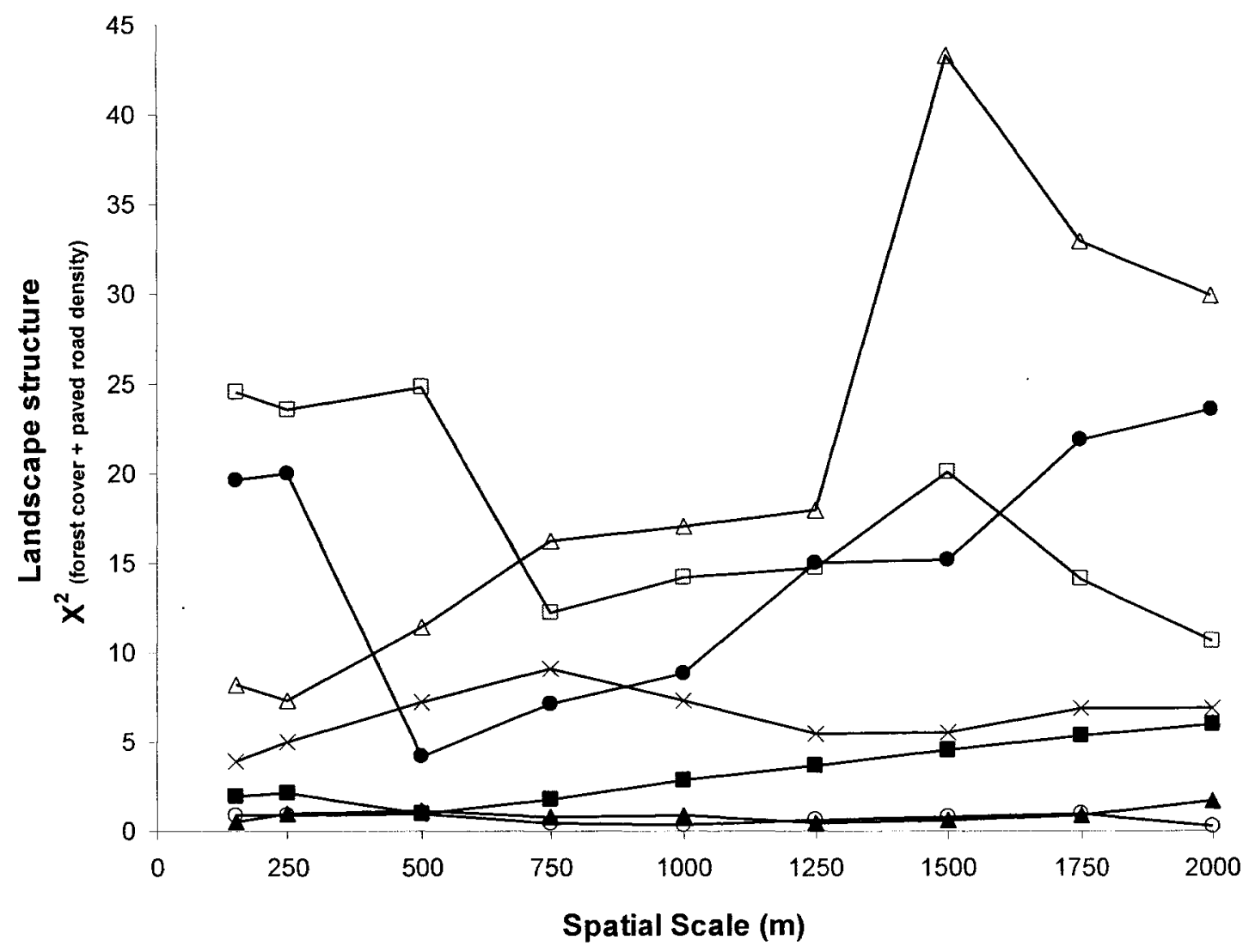

Figure 3. $\mathrm{X}^{2}$ values associated with the effect of landscape structure (forest cover plus paved road density) from separate models at each scale for each species using multiple multinomial logistic regression analyses. American Toad ( $\square$ ), Green Frog, ( $\mathbf{\Lambda})$, Gray Treefrog $(\times)$, Western Chorus Frog $(\boldsymbol{\square})$, Spring Peeper $(\Delta)$, Northern Leopard Frog $(\bullet)$, Wood Frog (O). 


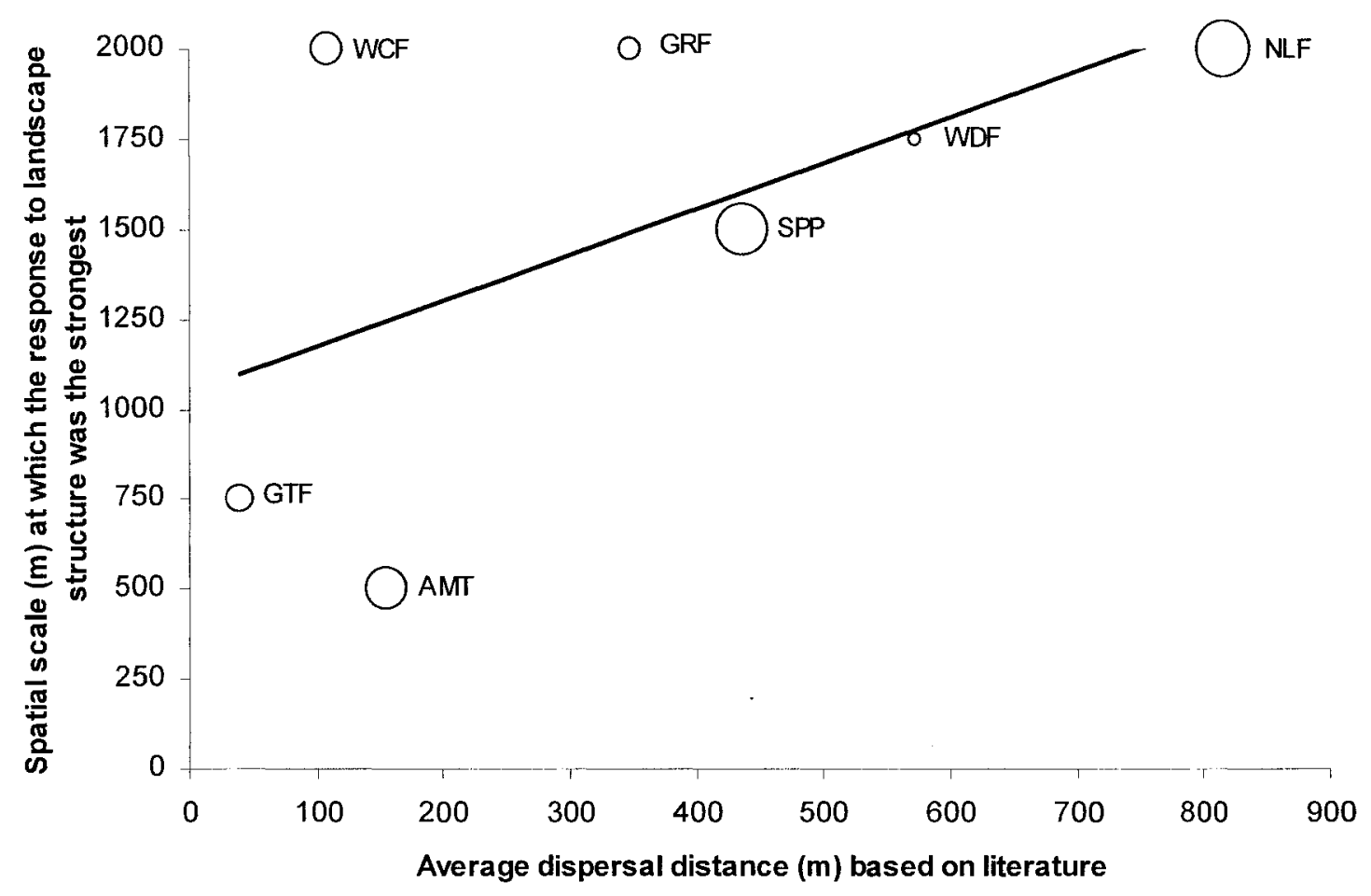

Figure 4. Relationship between average known dispersal distance based on the literature and the spatial scale at which the response to landscape structure was the strongest (Table 4) for each of the study anurans $(r=0.767$, p-value $=0.045)$. AMT: American Toad, GTF: Gray Treefrog, WCF: Western Chorus Frog, SPP: Spring Peeper, NLF: Northern Leopard Frog, WDF: Wood Frog, GRF: Green Frog. 


\section{Forest Cover}

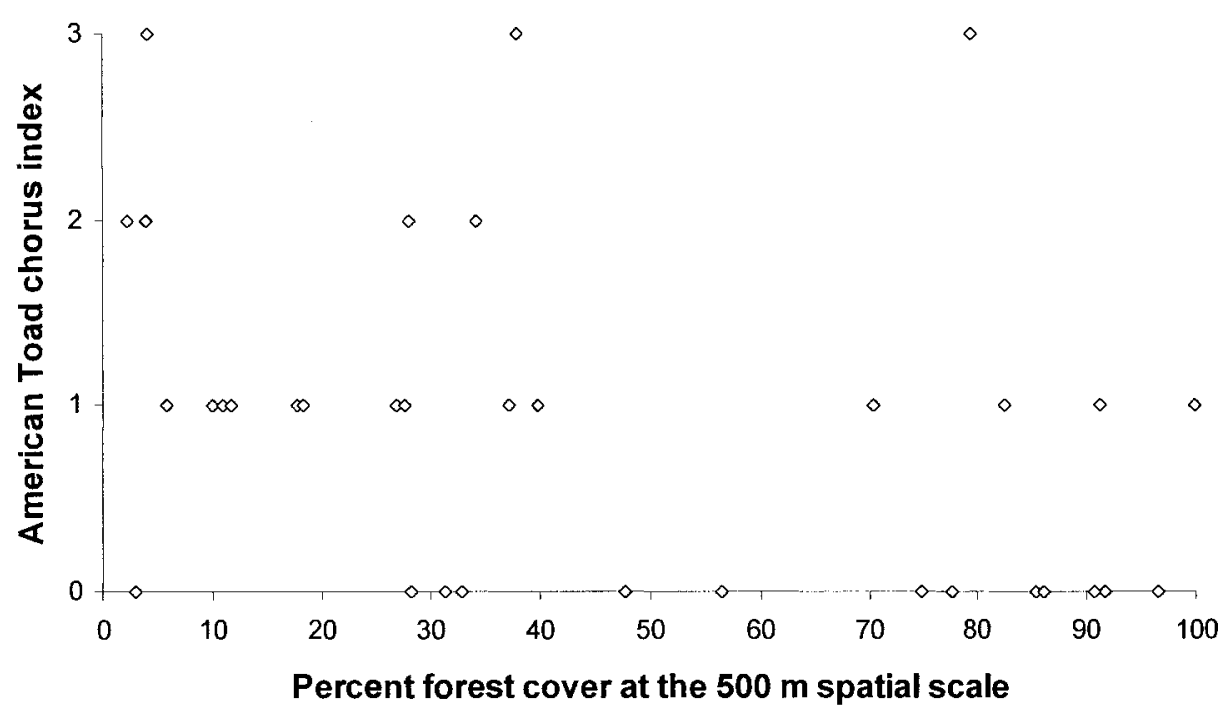

Figure 5. The relationship between American Toad chorus index and percent forest cover at the $500 \mathrm{~m}$ spatial scale.

\section{Paved Road Density}

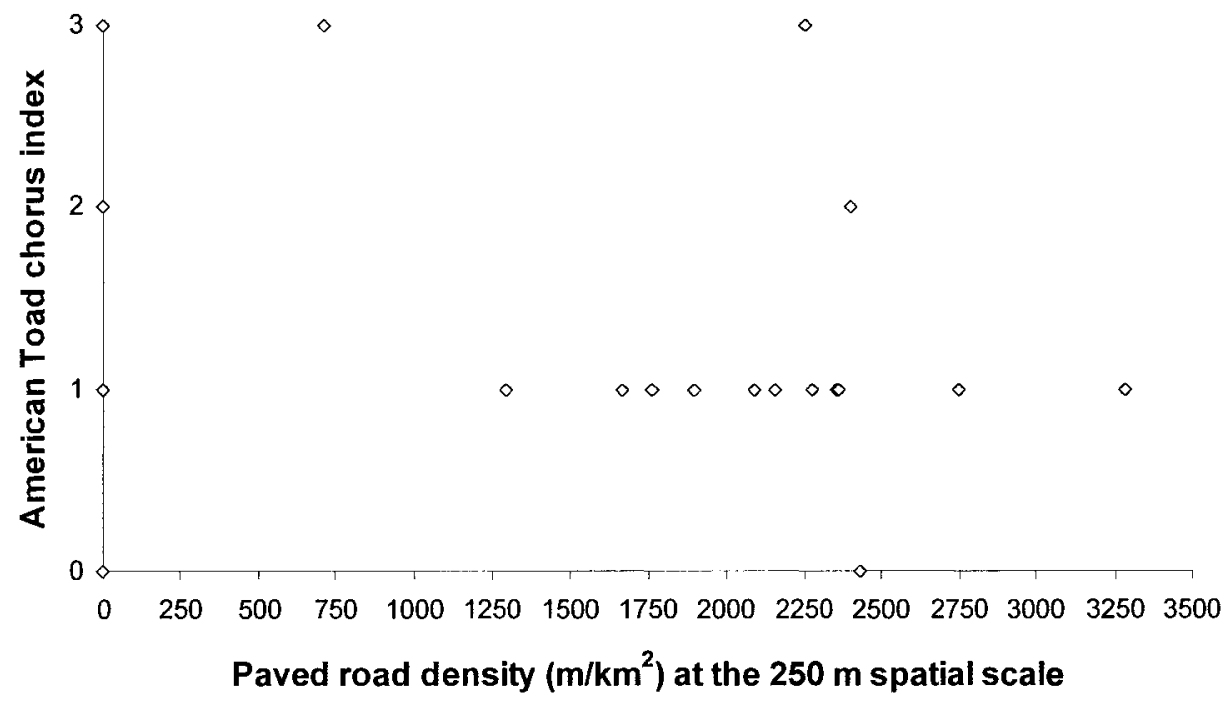

Figure 6. The relationship between American Toad chorus index and paved road density at the $250 \mathrm{~m}$ spatial scale. 
Forest Cover

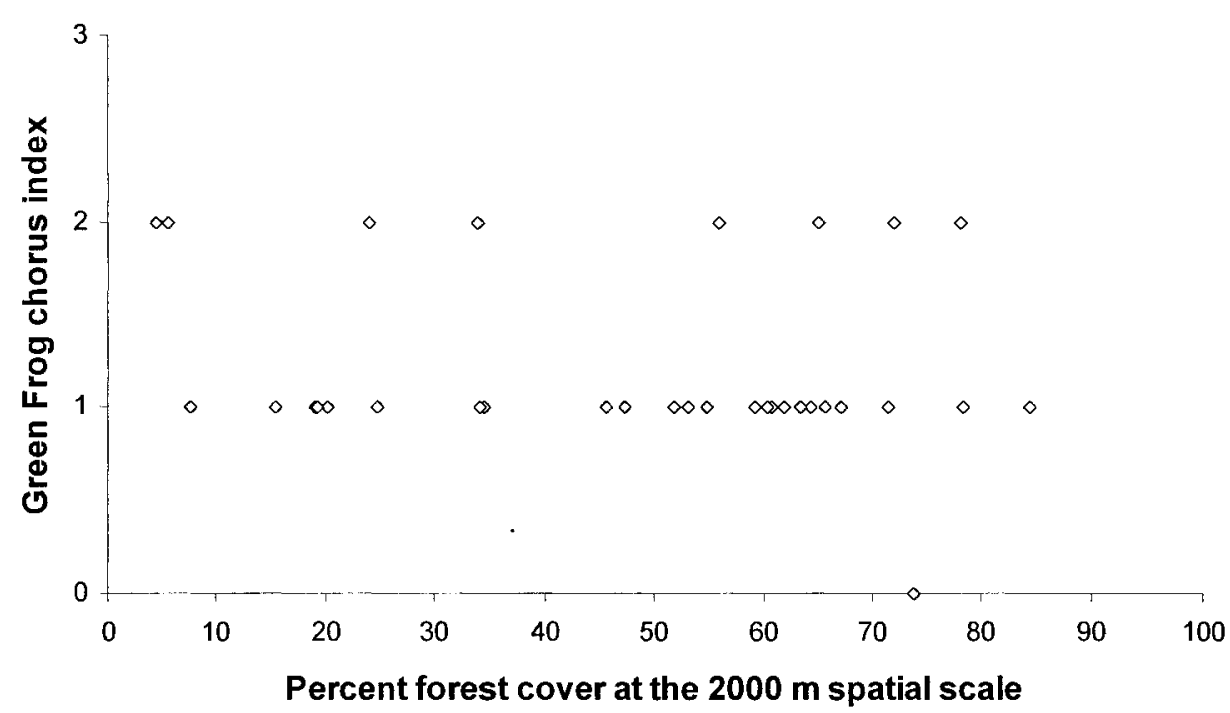

Figure 7. The relationship between Green Frog chorus index and percent forest cover at the $2000 \mathrm{~m}$ spatial scale.

\section{Paved Road Density}

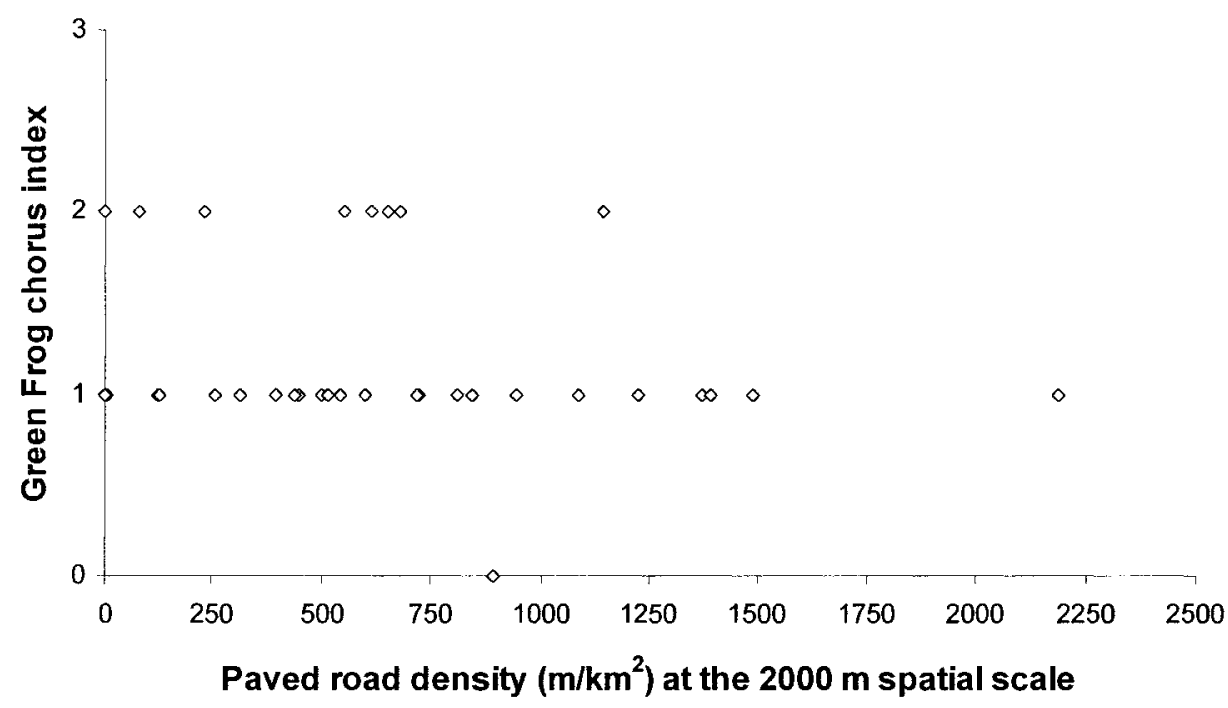

Figure 8. The relationship between Green Frog chorus index and paved road density at the $2000 \mathrm{~m}$ spatial scale. 


\section{Forest Cover}

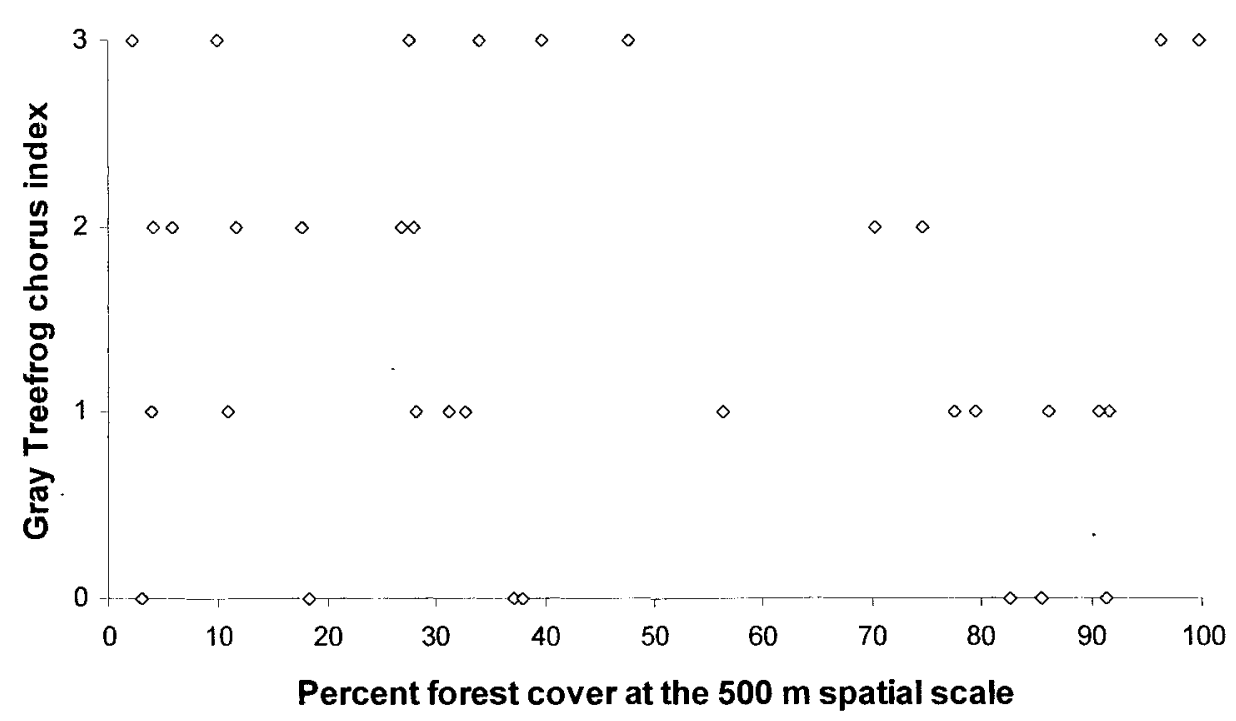

Figure 9. The relationship between Gray Treefrog chorus index and percent forest cover at the $500 \mathrm{~m}$ spatial scale.

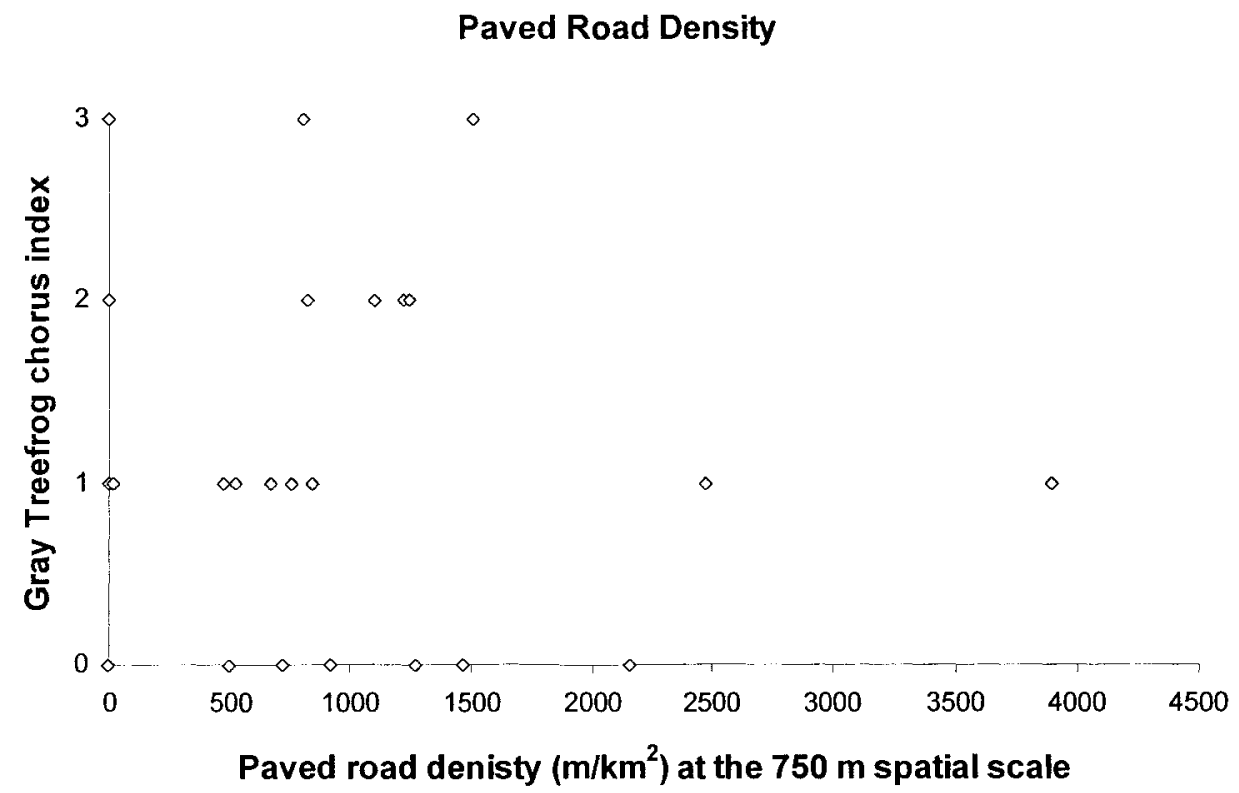

Figure 10. The relationship between Gray Treefrog chorus index and paved road density at the $750 \mathrm{~m}$ spatial scale. 


\section{Forest Cover}

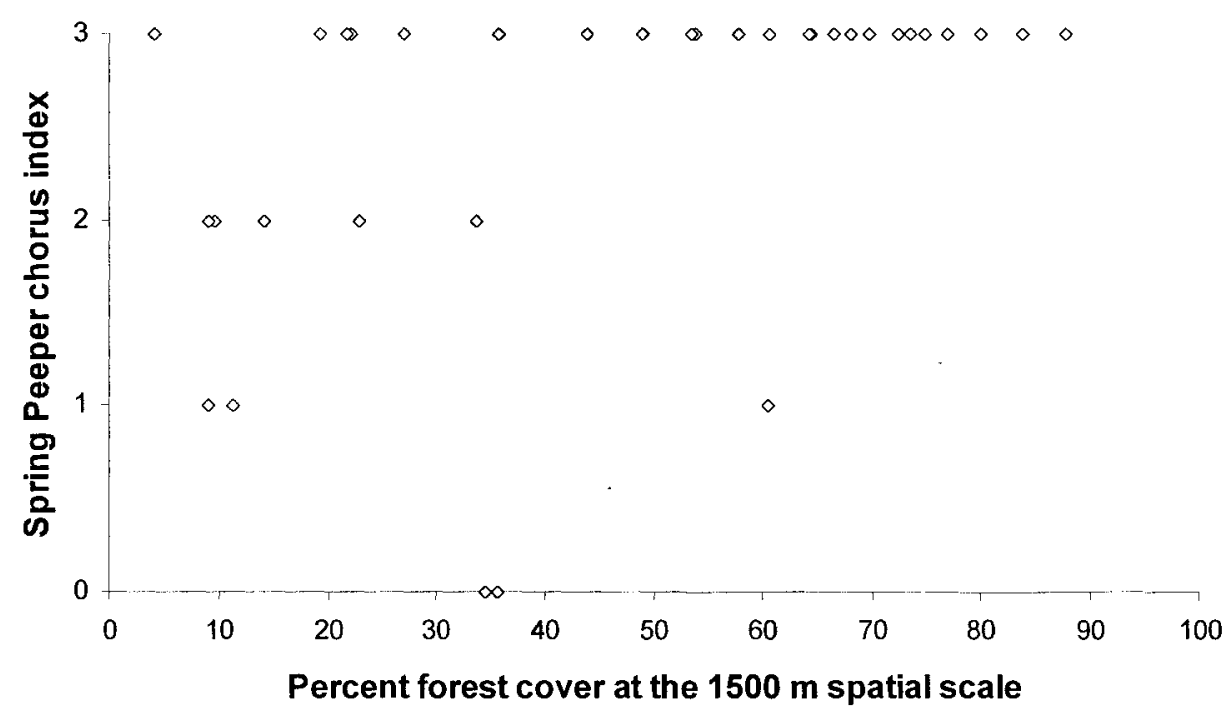

Figure 11. The relationship between Spring Peeper chorus index and percent forest cover at the $1500 \mathrm{~m}$ spatial scale.

\section{Paved Road Density}

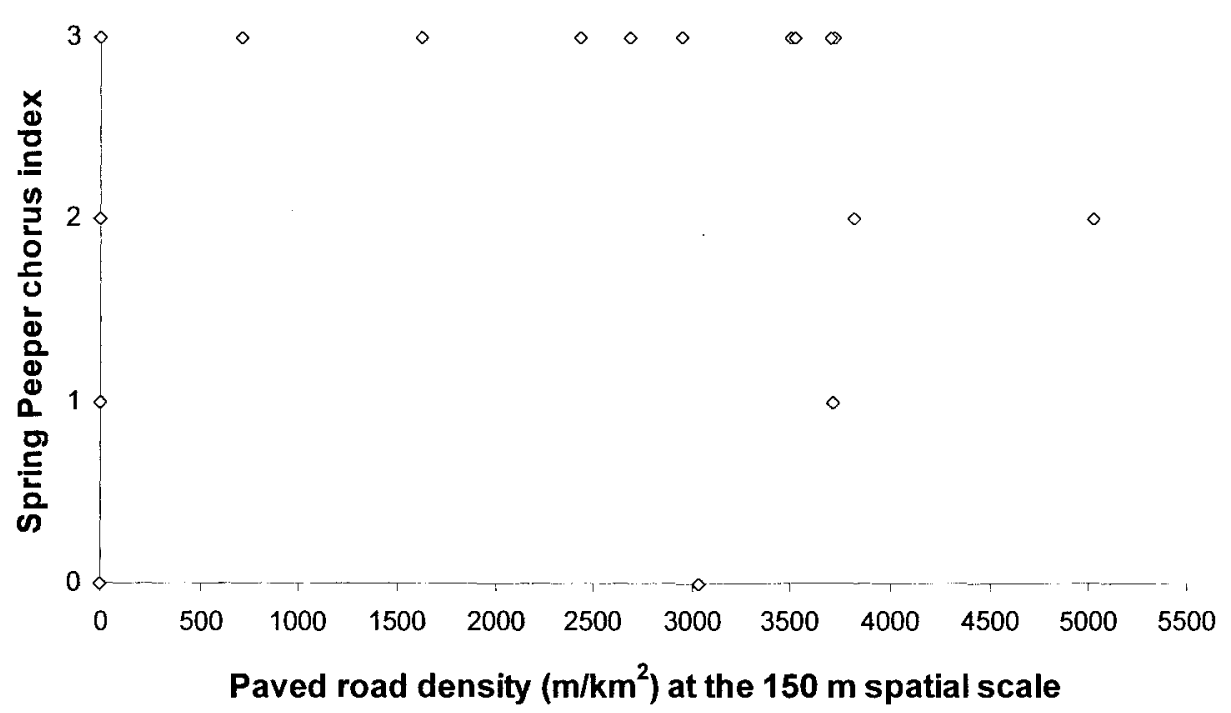

Figure 12. The relationship between Spring Peeper chorus index and paved road density at the $150 \mathrm{~m}$ spatial scale. 
Forest Cover

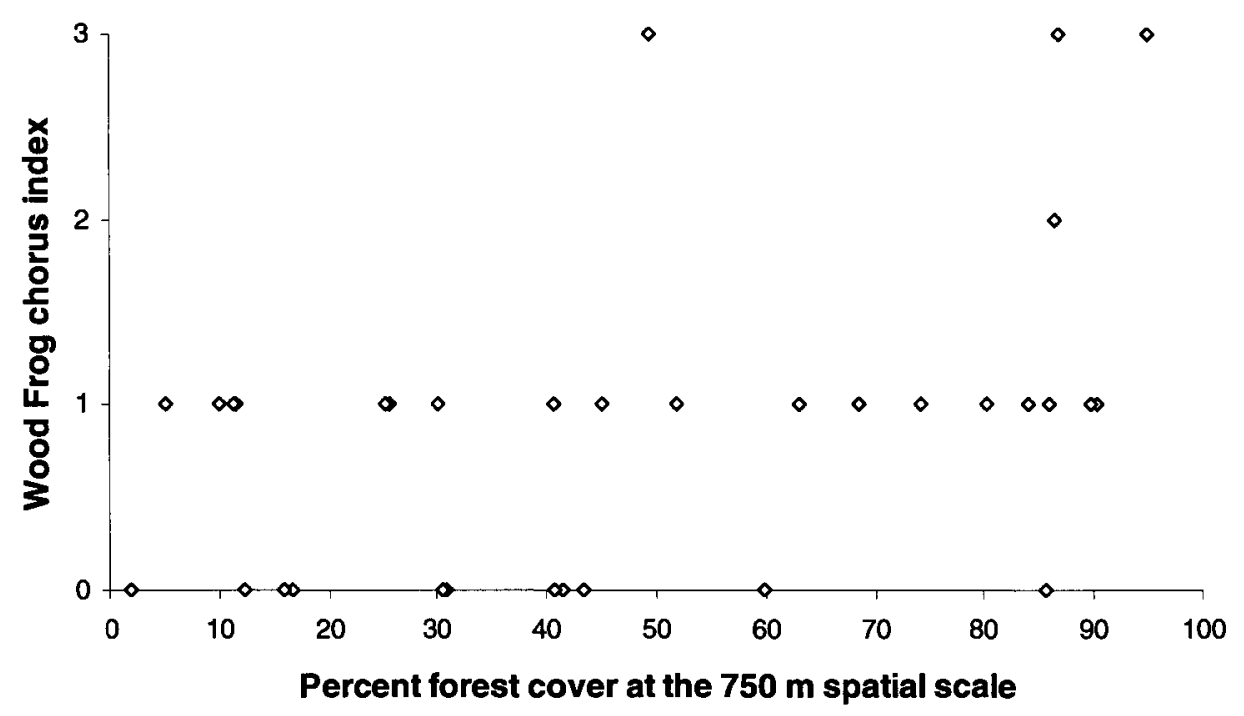

Figure 13. The relationship between Wood Frog chorus index and percent forest cover at the $750 \mathrm{~m}$ spatial scale.

\section{Paved Road Density}

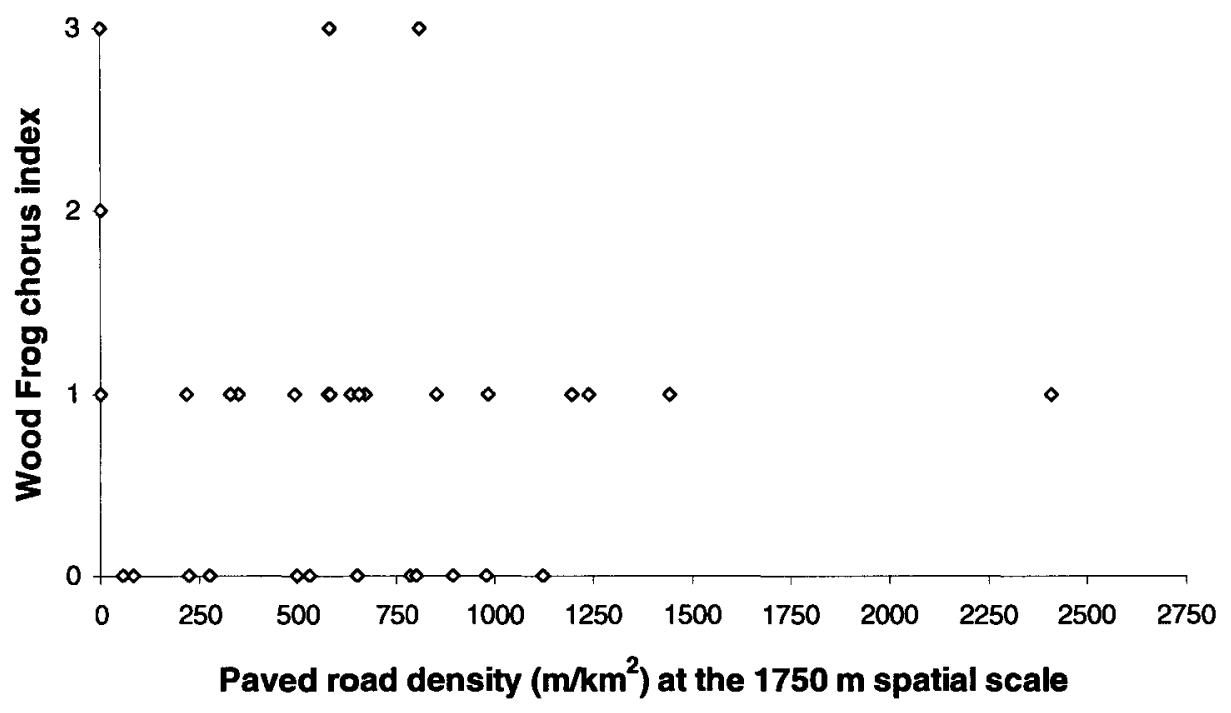

Figure 14. The relationship between Wood Frog chorus index and paved road density at the $1750 \mathrm{~m}$ spatial scale. 


\section{Forest Cover}

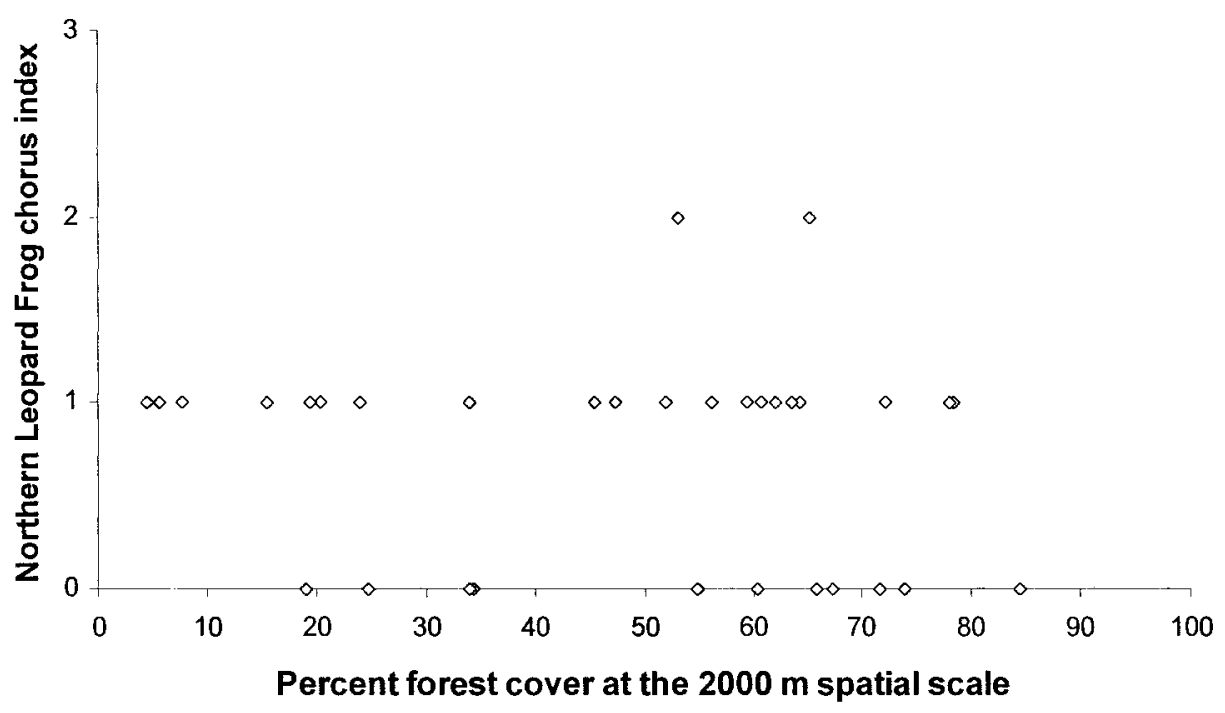

Figure 15. The relationship between Northern Leopard Frog chorus index and percent forest cover at the $2000 \mathrm{~m}$ spatial scale.

Paved Road Density

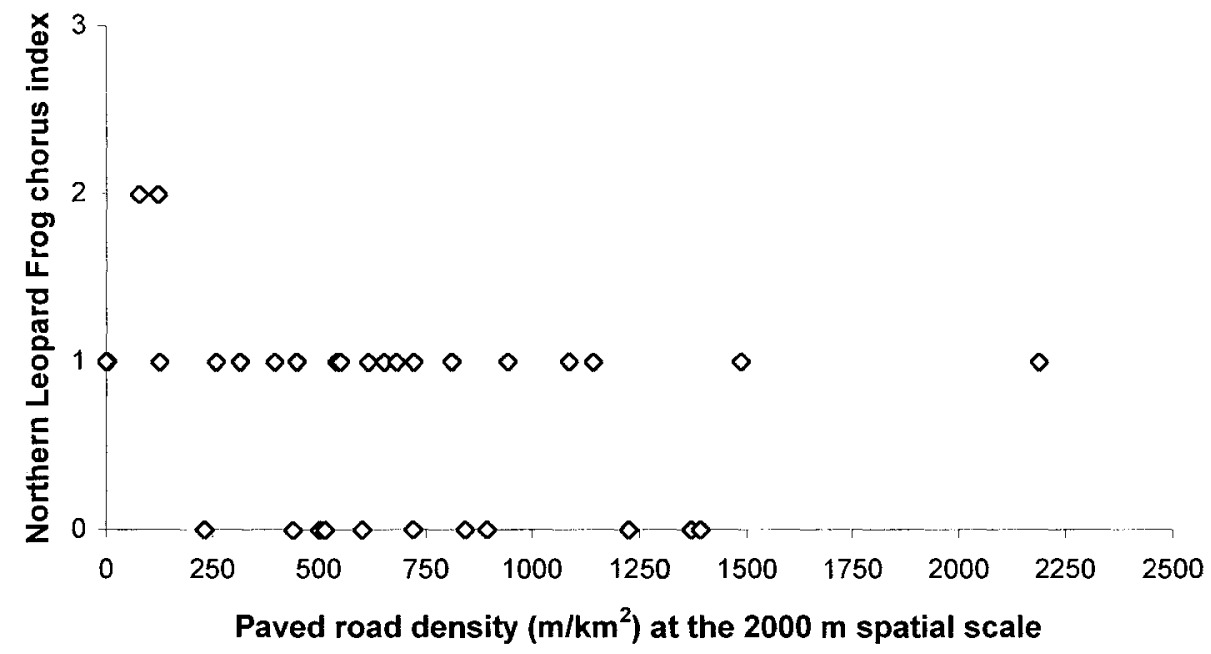

Figure 16. The relationship between Northern Leopard Frog chorus index and paved road density at the $2000 \mathrm{~m}$ spatial scale. 


\section{Forest Cover}

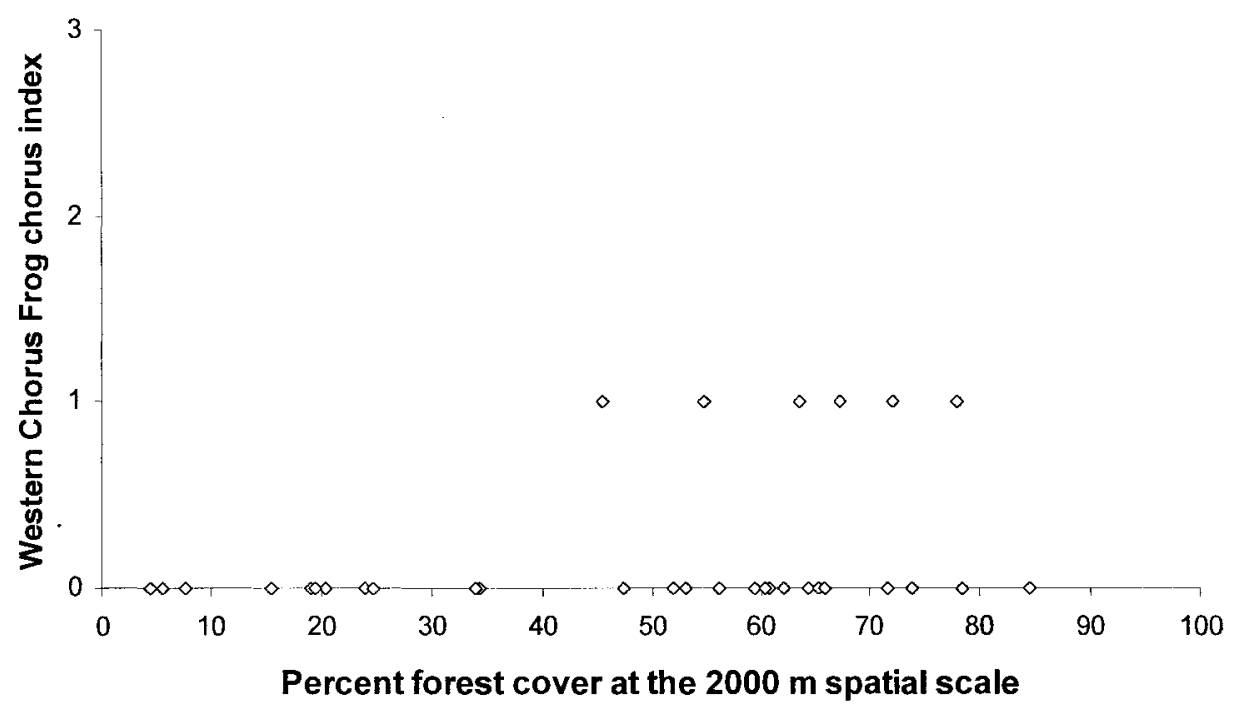

Figure 17. The relationship between Western Chorus Frog chorus index and percent forest cover at the $2000 \mathrm{~m}$ spatial scale.

\section{Paved Road Density}

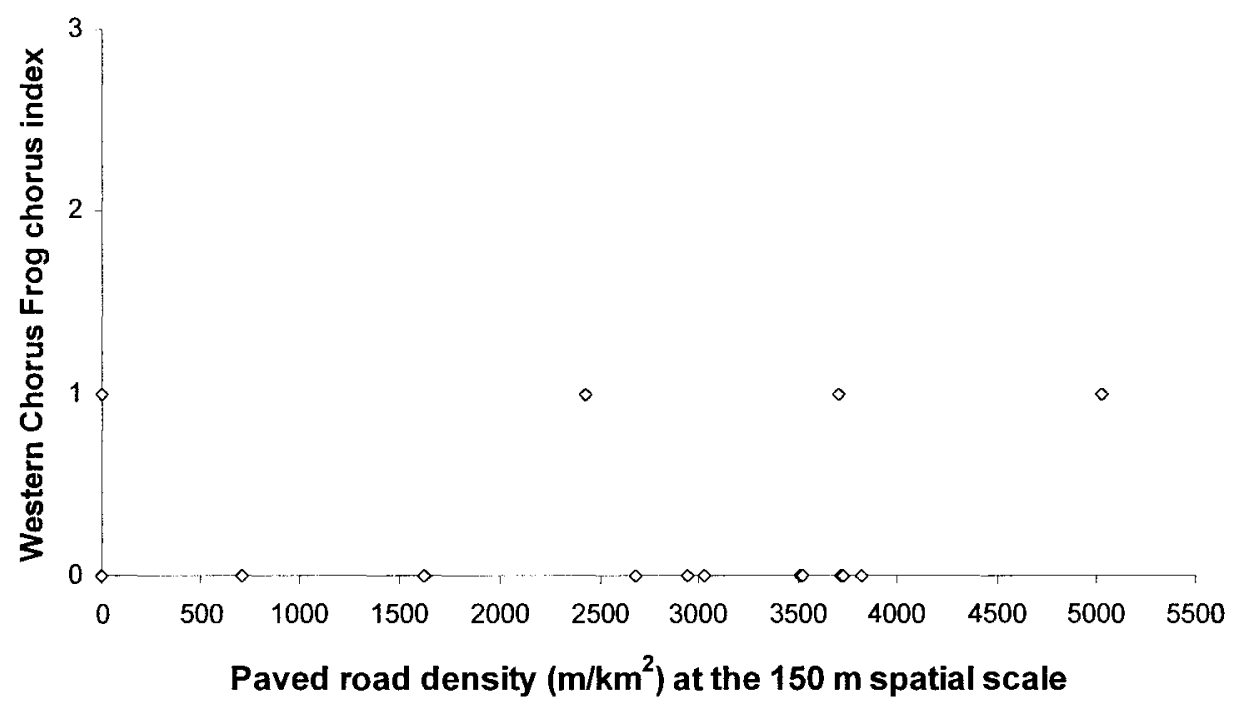

Figure 18. The relationship between Western Chorus Frog chorus index and paved road density at the $150 \mathrm{~m}$ spatial scale. 


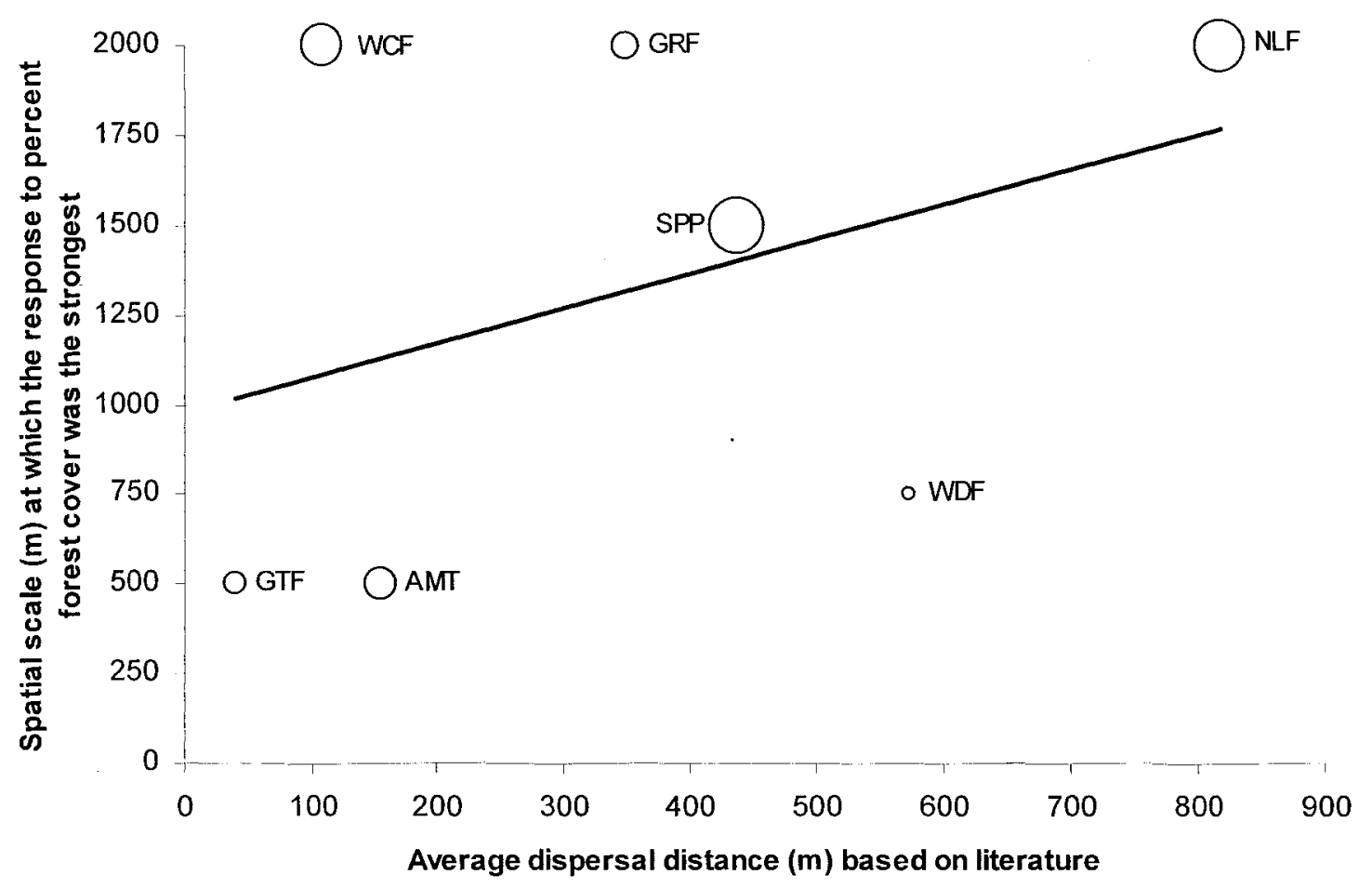

Figure 19. Relationship between average known dispersal distance based on the literature and the spatial scale at which response to percent forest cover was the strongest (Tables 9 and 10) for each of the study anurans $(r=0.599$, $\mathrm{p}$-value $=0.259)$. AMT: American Toad, GTF: Gray Treefrog, WCF: Western Chorus Frog, SPP: Spring Peeper, NLF: Northern Leopard Frog, WDF: Wood Frog, GRF: Green Frog. 


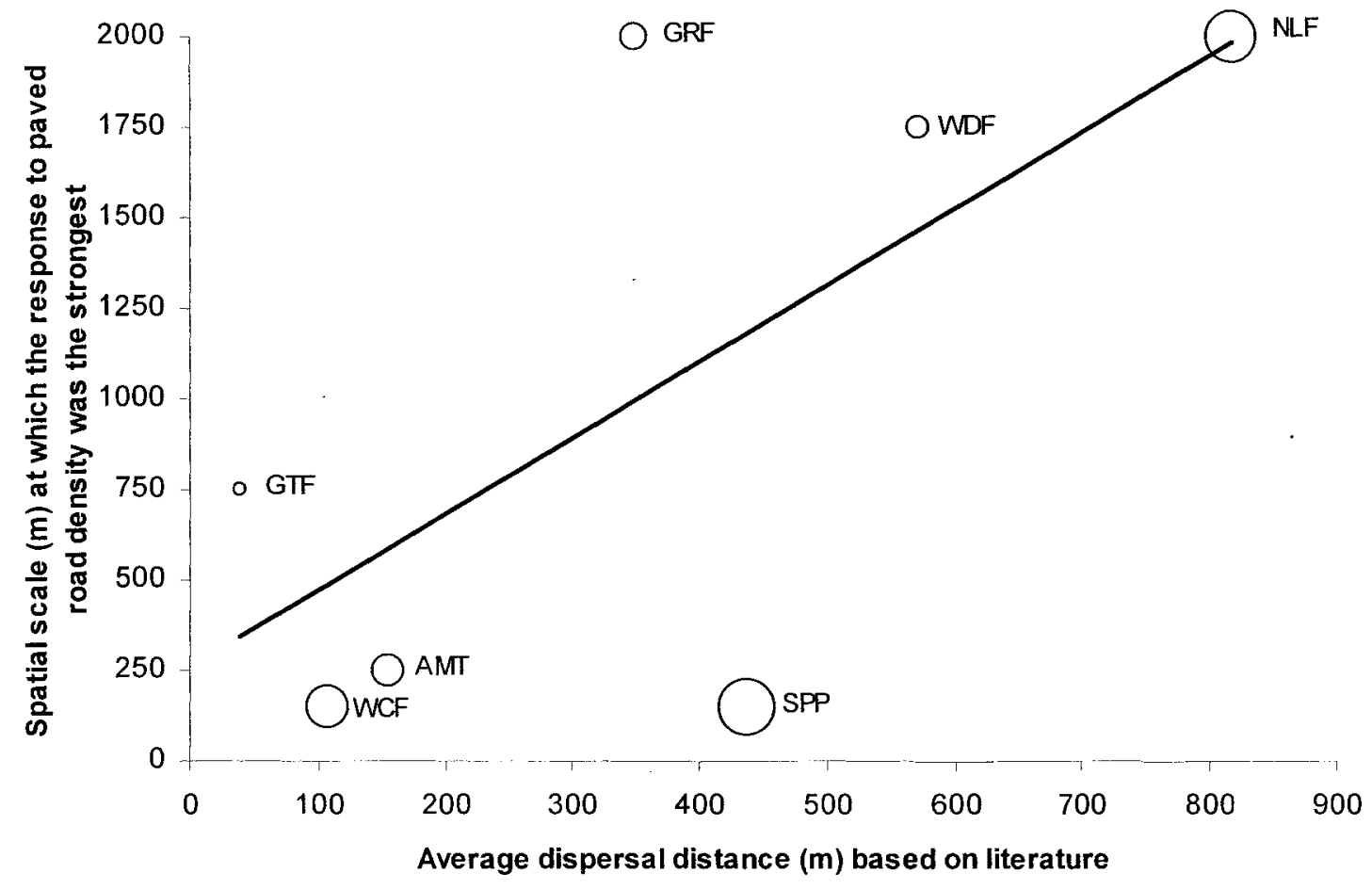

Figure 20. Relationship between average known dispersal distance based on the literature and the spatial scale at which response to paved road density was the strongest (Table 9 and 10$)$ for each of the study anurans $(r=0.828$, p-value $=0.034)$. AMT: American Toad, GTF: Gray Treefrog, WCF: Western Chorus Frog, SPP: Spring Peeper, NLF: Northern Leopard Frog, WDF: Wood Frog, GRF: Green Frog. 
Appendix A. Largest anuran chorus indices, percent forest at each scale, paved road density at each scale, average $\mathrm{pH}$, pond perimeter, and average pond vegetation (surface vegetation (SURF.V), emergent vegetation (EMERG.V), submerged vegetation (SUBM.V), and open water OPEN.V)) used in the analysis for each anuran.

\begin{tabular}{|c|c|c|c|c|c|c|c|c|c|c|c|c|c|c|c|c|c|c|c|c|c|c|c|c|c|c|c|c|c|c|c|}
\hline \multirow{3}{*}{ 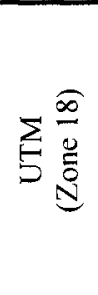 } & \multicolumn{7}{|c|}{ Dependent Variables } & \multicolumn{18}{|c|}{ Independent Landscape Variables } & \multicolumn{6}{|c|}{ Independent Local Variables } \\
\hline & \multicolumn{7}{|c|}{ Anuran Chorus Index } & \multicolumn{9}{|c|}{$\%$ Forest Cover } & \multicolumn{9}{|c|}{ Paved Road Density $\left(\mathrm{km} / \mathrm{km}^{2}\right)$} & \multirow[b]{2}{*}{ 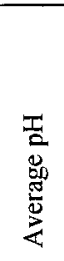 } & \multirow[b]{2}{*}{ 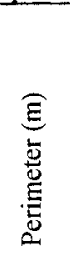 } & \multicolumn{4}{|c|}{$\begin{array}{c}\text { Ave } \% \\
\text { Vegetation }\end{array}$} \\
\hline & $\sum_{i}$ & 岕 & 岕 & 宸 & $\frac{\hat{\partial}}{\dot{s}}$ & $\frac{1}{3}$ & $\stackrel{4}{3}$ & $\begin{array}{l}\Xi \\
\text { E⿱口 } \\
\text { 号 }\end{array}$ & 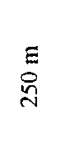 & $\begin{array}{l}E \\
\stackrel{\circ}{n}\end{array}$ & E & $\begin{array}{l}\Xi \\
8 \\
\varrho\end{array}$ & 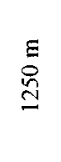 & \begin{tabular}{l}
$E$ \\
8 \\
8 \\
\hdashline
\end{tabular} & $\begin{array}{l}E \\
\stackrel{B}{D} \\
=\end{array}$ & $\begin{array}{l}\mathbf{E} \\
8 \\
8\end{array}$ & E & 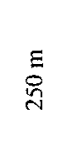 & $\stackrel{E}{8}$ & $\begin{array}{c}E \\
\text { 员 } \\
\text { n }\end{array}$ & $\begin{array}{l}E \\
8 \\
8\end{array}$ & 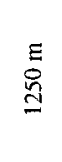 & \begin{tabular}{l}
$E$ \\
8 \\
8 \\
\hdashline \\
-10
\end{tabular} & $\begin{array}{l}E \\
\stackrel{\circ}{\varrho}\end{array}$ & $\begin{array}{l}\Xi \\
\stackrel{8}{8} \\
\end{array}$ & & & 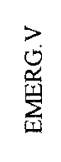 & $\begin{array}{l}\text { 点 } \\
\text { 点 }\end{array}$ & 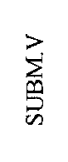 & $\begin{array}{l}> \\
z \\
z \\
z \\
0\end{array}$ \\
\hline $\begin{array}{r}384829 \\
5024416\end{array}$ & 1 & $\cdot$ & 3 & 0 & 3 & 0 & 3 & 12 & 28 & 40 & 49 & 58 & 68 & 75 & 76 & 74 & 0.00 & 1.90 & 1.57 & 1.52 & 1.23 & 1.01 & 0.91 & 0.81 & 0.89 & - & 93 & 0 & 0 & so & 50 \\
\hline $\begin{array}{r}408212 \\
5036478\end{array}$ & 1 & 1 & 2 & 1 & 2 & 1 & 0 & 10 & 22 & 18 & 17 & 23 & 28 & 34 & 41 & 46 & 5.03 & 3.29 & 1.78 & 1.22 & 1.08 & 0.92 & 0.79 & 0.79 & 0.72 & 9 & 415 & 20 & 0 & 20 & 70 \\
\hline $\begin{array}{r}394358 \\
5045974\end{array}$ & 0 & 2 & 3 & 1 & 3 & 0 & 3 & 100 & 100 & 97 & 87 & 77 & 71 & 67 & 61 & 56 & 0.00 & 0.00 & 0.00 & 0.00 & 0.00 & 0.44 & 0.49 & 0.58 & 0.62 & 6 & 363 & 10 & 0 & 0 & 90 \\
\hline $\begin{array}{c}472022 \\
5052866\end{array}$ & 0 & 1 & 1 & 0 & 3 & 0 & 1 & 100 & 99 & 92 & 90 & 87 & 87 & 88 & 86 & 84 & 0.00 & 0.00 & 0.00 & 0.47 & 0.48 & 0.44 & 0.59 & 0.86 & 0.84 & 8 & 70 & 30 & 0 & 0 & 70 \\
\hline $\begin{array}{l}488527 \\
5064202\end{array}$ & 0 & 1 & 1 & 1 & 3 & 0 & 1 & 0 & 13 & 31 & 30 & 30 & 33 & 36 & 42 & 47 & 0.00 & 0.00 & 0.96 & 0.76 & 0.59 & 0.48 & 0.47 & 0.49 & 0.45 & 8 & 285 & 30 & 20 & 10 & 40 \\
\hline $\begin{array}{c}491398 \\
4987097\end{array}$ & 3 & 1 & 1 & 1 & 3 & 0 & 1 & 97 & 89 & 79 & 74 & 73 & 71 & 68 & 66 & 64 & 0.71 & 0.71 & 0.63 & 0.52 & 0.44 & 0.39 & 0.37 & 0.35 & 0.40 & 7 & 1737 & 40 & 10 & 30 & 30 \\
\hline $\begin{array}{c}428353 \\
4987629\end{array}$ & 2 & 1 & 2 & 2 & 3 & 0 & 0 & 0 & 4 & 28 & 43 & 44 & 48 & 49 & 52 & 53 & 0.00 & 0.00 & 0.00 & 0.00 & 0.00 & 0.00 & 0.00 & 0.08 & 0.12 & 8 & 173 & 30 & 0 & 10 & 60 \\
\hline $\begin{array}{l}440055 \\
4974167\end{array}$ & 1 & 1 & 3 & 1 & 3 & 0 & 3 & 100 & 100 & 100 & 95 & 93 & 86 & 84 & 81 & 78 & 0.00 & 0.00 & 0.00 & 0.00 & 0.00 & 0.00 & 0.00 & 0.00 & 0.00 & 8 & 387 & 60 & 0 & 0 & 40 \\
\hline $\begin{array}{c}410114 \\
4952254\end{array}$ & 0 & 1 & 0 & 1 & 3 & 1 & 1 & 100 & 100 & 85 & 80 & 72 & 67 & 65 & 66 & 64 & 0.00 & 0.00 & 0.06 & 0.50 & 0.86 & 0.87 & 0.73 & 0.67 & 0.81 & - & - & - & - & - & - \\
\hline $\begin{array}{l}413263 \\
4992032\end{array}$ & 1 & 1 & 2 & 0 & 3 & 1 & 1 & 0 & 8 & 27 & 45 & $\$ 2$ & 52 & 54 & 54 & 55 & 2.44 & 1.76 & 1.05 & 1.25 & 0.98 & 0.81 & 0.68 & 0.58 & 0.50 & 8 & 487 & 50 & 0 & 10 & 30 \\
\hline $\begin{array}{c}425418 \\
4991295\end{array}$ & 2 & 1 & 3 & 1 & 3 & 0 & 1 & 30 & 36 & 34 & $4 i$ & 49 & 53 & 58 & 59 & 62 & 0.00 & 0.00 & 0.00 & 0.00 & 0,00 & 0.00 & 0.00 & 0.00 & 0.00 & - & 838 & 0 & 0 & - & 100 \\
\hline $\begin{array}{l}405475 \\
5021720\end{array}$ & 1 & 1 & 0 & 0 & 0 & - & - & 19 & 31 & 37 & 42 & 38 & 36 & 34 & 35 & 34 & 3.03 & 2.16 & 1.19 & 1.27 & 1.34 & 1.11 & 0.93 & 0.80 & 0.72 & 10 & 163 & 20 & 0 & 0 & 80 \\
\hline $\begin{array}{l}4.18728 \\
5044613\end{array}$ & 0 & 1 & 3 & 1 & 3 & 0 & 1 & 81 & 61 & 48 & 63 & 67 & 64 & 61 & 59 & 59 & 0,00 & 0.00 & 0.00 & 0.00 & 0.18 & 0.39 & 0.36 & 0.33 & 0.32 & 7 & 394 & 40 & 10 & 20 & 40 \\
\hline $\begin{array}{c}468944 \\
4993249\end{array}$ & 3 & 2 & 2 & 1 & 1 & 0 & 1 & 0 & 0 & 4 & 12 & 14 & 12 & 9 & 7 & 6 & 0.00 & 0.00 & 0.00 & 0.00 & 0.00 & 0.34 & 0.57 & 0.64 & 0.65 & 10 & 194 & 30 & 10 & - & 70 \\
\hline
\end{tabular}




\begin{tabular}{|c|c|c|c|c|c|c|c|c|c|c|c|c|c|c|c|c|c|c|c|c|c|c|c|c|c|c|c|c|c|c|c|}
\hline \multirow{3}{*}{$\sum \frac{\infty}{0}$} & \multirow{2}{*}{\multicolumn{7}{|c|}{ Dependent Variables }} & \multicolumn{18}{|c|}{ Independent Landscape Variables } & \multicolumn{6}{|c|}{$\begin{array}{c}\text { Independent Local } \\
\text { Variables }\end{array}$} \\
\hline & & & & & & & & \multicolumn{9}{|c|}{$\%$ Forest Cover } & \multicolumn{9}{|c|}{ Paved Road Density $\left(\mathrm{km} / \mathrm{km}^{2}\right)$} & \multirow[b]{2}{*}{ 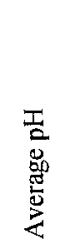 } & \multirow[b]{2}{*}{ 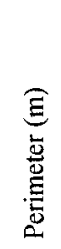 } & \multicolumn{4}{|c|}{$\begin{array}{c}\text { Ave } \% \\
\text { Vegetation }\end{array}$} \\
\hline & $\sum_{k}$ & 岩 & $E^{L}$ & 岇 & 空 & $\stackrel{w}{3}$ & $\stackrel{5}{\hat{S}}$ & 是 & 芯 & E & 몽 & 草 & $\begin{array}{l}E \\
\stackrel{5}{8} \\
\cong\end{array}$ & 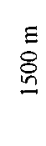 & 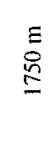 & $\begin{array}{l}E \\
\stackrel{8}{8} \\
\text { N }\end{array}$ & $\stackrel{E}{\mathscr{6}}$ & $\stackrel{E}{5}$ & $\begin{array}{l}\Xi \\
8 \\
i_{n}\end{array}$ & $\begin{array}{l}E \\
\stackrel{n}{n}\end{array}$ & $\begin{array}{l}\Xi \\
8 \\
\varnothing \\
\end{array}$ & $\begin{array}{l}\Xi \\
\emptyset \\
气\end{array}$ & $\begin{array}{l}E \\
8 \\
8 \\
-\end{array}$ & 总 & 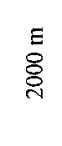 & & & 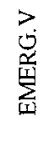 & $\begin{array}{l}> \\
\stackrel{4}{5} \\
\stackrel{5}{5}\end{array}$ & 总 & $\begin{array}{l}> \\
\text { zin } \\
\text { on }\end{array}$ \\
\hline $\begin{array}{l}484482 \\
4988348\end{array}$ & 3 & 1 & 0 & 1 & 3 & 0 & 0 & $4 I$ & 32 & 38 & 31 & 28 & 23 & 19 & 18 & 20 & 3.51 & 2.26 & 1.90 & 1.47 & 1.15 & 1.18 & 1.11 & 0.98 & 0.94 & 8 & 244 & 40 & 0 & 10 & 40 \\
\hline $\begin{array}{l}462198 \\
5016998\end{array}$ & 1 & 1 & 3 & 1 & 3 & 0 & 1 & 0 & 3 & 10 & 11 & 16 & 21 & 22 & 21 & 19 & 2.95 & 2.09 & 1.17 & 0.80 & 0.83 & 1.08 & 1.02 & 0.99 & 1.09 & 8 & 280 & 60 & 0 & 0 & 40 \\
\hline $\begin{array}{l}440690 \\
4965828\end{array}$ & 0 & 1 & 1 & 1 & 3 & 0 & 1 & 59 & 62 & 57 & 52 & 49 & 51 & 54 & 58 & 61 & 0.00 & 0.00 & 0.00 & 0.00 & 0.00 & 0.00 & 0.00 & 0.00 & 0.00 & 7 & 620 & 50 & 30 & & 20 \\
\hline $\begin{array}{l}458520 \\
4981687\end{array}$ & 0 & 2 & 1 & 0 & 0 & 0 & 0 & 48 & 40 & 28 & 30 & 35 & 35 & 36 & 36 & 34 & 0.00 & 0.00 & 0.00 & 0.00 & 0.00 & 0.00 & 0.16 & 0.22 & 0.23 & 8 & 155 & 30 & 10 & 10 & 60 \\
\hline $\begin{array}{l}429123 \\
4944355\end{array}$ & 0 & 2 & 1 & 1 & 2 & 0 & 1 & 10 & 22 & 33 & 26 & 22 & 21 & 23 & 23 & 24 & 0.00 & 0.00 & 0.73 & 0.67 & 0.55 & 0.48 & 0.49 & 0.66 & 0.68 & 8 & 287 & 60 & 0 & 20 & 40 \\
\hline $\begin{array}{l}448918 \\
4969616\end{array}$ & 0 & 2 & 1 & 1 & 3 & 1 & 2 & 84 & 84 & 86 & 87 & 82 & 79 & 77 & 78 & 78 & 0.00 & 0.00 & 0.00 & 0.00 & 0.00 & 0.00 & 0.00 & 0.00 & 0.00 & 7 & 124 & 40 & 10 & 0 & 50 \\
\hline $\begin{array}{l}400968 \\
4985007\end{array}$ & 1 & 2 & 2 & 2 & 3 & 0 & 1 & 75 & 70 & 70 & 69 & 72 & 73 & 70 & 66 & 65 & 0.00 & 0.00 & 0.00 & 0.00 & 0.00 & 0.00 & 0.00 & 0.00 & 0.08 & 7 & 37 & 10 & 0 & 0 & $\begin{array}{l}10 \\
0\end{array}$ \\
\hline $\begin{array}{l}391228 \\
4993460\end{array}$ & 0 & 1 & 2 & 1 & 3 & 0 & 0 & 83 & 80 & 75 & 60 & 50 & 45 & 44 & 49 & 52 & 0.00 & 0.00 & 0.00 & 0.00 & 0.00 & 0.00 & 0.42 & 0.50 & 0.54 & 8 & 85 & 40 & 0 & - & 60 \\
\hline Site 205 & 2 & 1 & 1 & D & 2 & 0 & 0 & 0 & 1 & 4 & 2 & 3 & 6 & 10 & 14 & 19 & 3.83 & 2.41 & 1.24 & 0.84 & 0.63 & 0.51 & 0,68 & 0,90 & 1.37 & 8 & 107 & 20 & 20 & - & 70 \\
\hline $\begin{array}{l}453668 \\
4993964\end{array}$ & 2 & 1 & 3 & 1 & 2 & 0 & 0 & 6 & 7 & 2 & 2 & 4 & 8 & 9 & 8 & 8 & 0.00 & 0.00 & 0.00 & 0.00 & 0,00 & 0.01 & 0.04 & 0.06 & 0.13 & 8 & 119 & 0 & 0 & 0 & $\begin{array}{l}10 \\
0\end{array}$ \\
\hline $\begin{array}{l}474028 \\
5017071\end{array}$ & 1 & 2 & 2 & 1 & 3 & 0 & 1 & 0 & 3 & 6 & 5 & 4 & 4 & 4 & 4 & 4 & 3.52 & 2.28 & 1.21 & 0.83 & 0.63 & 0.51 & 0.59 & 0.58 & 0.55 & 8 & 142 & 60 & 10 & 0 & 30 \\
\hline $\begin{array}{l}442620 \\
5006731\end{array}$ & 1 & 1 & 1 & 1 & 1 & 0 & 1 & 0 & 8 & 11 & 10 & 11 & 13 & 11 & 14 & 19 & 3.72 & 2.75 & 2.52 & 3.90 & 3.13 & 2.71 & 2.57 & 2.41 & 2.19 & 8 & 143 & 10 & 10 & 50 & 60 \\
\hline $\begin{array}{l}444691 \\
5042675\end{array}$ & 0 & 1 & 1 & 0 & 3 & 0 & 1 & 97 & 92 & 91 & 90 & 84 & 78 & 73 & 69 & 66 & 0.00 & 0.00 & 0.00 & 0.01 & 0.08 & 0.10 & 0.13 & 0.22 & 0.44 & 8 & 681 & 40 & 30 & 40 & 20 \\
\hline $\begin{array}{l}424136 \\
4999238\end{array}$ & 1 & 1 & 2 & 0 & 3 & 0 & 0 & 8 & 11 & 12 & 16 & 19 & 20 & 22 & 23 & 25 & 3.73 & 2.36 & 1.23 & 1.10 & 0.87 & 0.73 & 0.71 & 0.65 & 0.60 & 10 & 219 & 20 & 30 & 20 & 40 \\
\hline $\begin{array}{l}457383 \\
5025771\end{array}$ & 1 & 1 & 0 & 1 & 3 & 0 & 1 & 0 & 6 & 18 & 25 & 26 & 25 & 27 & 30 & 34 & 1.62 & 1.30 & 0.87 & 0.72 & 1.18 & 1.13 & 1.23 & 1.44 & 1.49 & 7 & 895 & 80 & 0 & 0 & 20 \\
\hline $\begin{array}{l}434909 \\
5032152\end{array}$ & $i$ & 1 & 0 & 0 & 1 & 0 & 1 & 92 & 81 & 83 & 86 & 77 & 68 & 61 & 59 & 60 & 0.00 & 1.67 & 1.00 & 0.92 & 1.05 & 1.12 & 1.06 & 1.20 & 1.23 & 8 & 735 & 30 & 0 & 10 & 70 \\
\hline
\end{tabular}


Appendix A. Continued

\begin{tabular}{|c|c|c|c|c|c|c|c|c|c|c|c|c|c|c|c|c|c|c|c|c|c|c|c|c|c|c|c|c|c|c|c|}
\hline \multirow{3}{*}{ 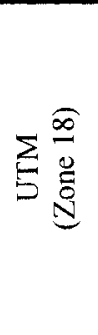 } & \multirow{2}{*}{\multicolumn{7}{|c|}{ Dependent Variables }} & \multicolumn{18}{|c|}{ Independent Landscape Variables } & \multicolumn{6}{|c|}{$\begin{array}{c}\text { Independent Local } \\
\text { Variables }\end{array}$} \\
\hline & & & & & & & & \multicolumn{9}{|c|}{$\%$ Forest Cover } & \multicolumn{9}{|c|}{ Paved Road Density $\left(\mathrm{km} / \mathrm{km}^{2}\right)$} & \multirow[b]{2}{*}{ 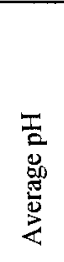 } & \multirow[b]{2}{*}{ 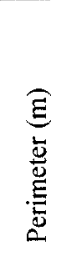 } & \multicolumn{4}{|c|}{$\begin{array}{c}\text { Ave \% } \\
\text { Vegetation } \\
\end{array}$} \\
\hline & $\sum_{<}^{5}$ & 岁 & E & 岁 & $\frac{2}{\infty}$ & 岁 & 岁 & E & ह & $\begin{array}{l}\text { E } \\
8 \\
\overbrace{}^{2}\end{array}$ & $\begin{array}{c}E \\
\text { 员 } \\
\text { n }\end{array}$ & $\begin{array}{l}\Xi \\
8 \\
\end{array}$ & $\begin{array}{l}E \\
\Xi \\
0 \\
\Xi \\
\Xi\end{array}$ & $\begin{array}{l}E \\
\stackrel{8}{ } \\
\stackrel{n}{-}\end{array}$ & 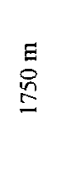 & $\begin{array}{l}\Xi \\
8 \\
8 \\
\end{array}$ & $\stackrel{\Xi}{5}$ & $\underset{n}{E}$ & $\stackrel{E}{8}$ & E & $\begin{array}{l}E \\
\stackrel{8}{O} \\
\end{array}$ & $\begin{array}{l}E \\
\stackrel{0}{0} \\
\stackrel{0}{=}\end{array}$ & $\begin{array}{l}E \\
8 \\
8 \\
-\end{array}$ & $\begin{array}{l}E \\
\stackrel{8}{E} \\
=\end{array}$ & $\begin{array}{l}\text { E } \\
8 \\
\end{array}$ & & & 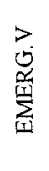 & $\begin{array}{l}\text { 离 } \\
\text { 岕 }\end{array}$ & 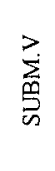 & 窑 \\
\hline $\begin{array}{l}413062 \\
5018798\end{array}$ & 1 & 2 & 0 & 1 & 3 & 1 & 1 & 100 & 100 & 91 & 84 & 79 & 76 & 74 & 72 & 72 & 3.71 & 2.37 & 1.52 & 2.16 & 1.95 & 1.66 & 1.42 & 1.24 & 1.14 & 8 & 146 & 10 & 30 & 40 & 40 \\
\hline $\begin{array}{l}409906 \\
5013120\end{array}$ & 1 & 1 & 3 & 0 & 3 & 1 & 0 & 7 & 15 & 28 & 41 & 50 & 60 & 64 & 66 & 67 & 0.00 & 0.00 & 0.00 & 0.00 & 0.38 & 0.39 & 0.51 & 0.53 & 0.52 & 9 & 177 & 40 & 0 & 20 & 30 \\
\hline $\begin{array}{l}462327 \\
5022827\end{array}$ & 0 & 1 & 1 & 0 & 3 & 0 & 0 & 86 & 79 & 78 & 86 & 87 & 85 & 80 & 76 & 72 & 2.68 & 2.43 & 3.16 & 2.47 & 1.91 & 1.56 & 1.31 & 1.12 & 1.39 & 8 & 121 & 40 & 10 & 10 & 50 \\
\hline $\begin{array}{l}410252 \\
5008436\end{array}$ & 0 & 1 & 0 & 1 & 2 & 0 & 0 & 11 & 8 & 3 & 12 & 13 & 13 & 14 & 15 & 16 & 0.00 & 0.00 & 0.00 & 0.00 & 0.00 & 0.21 & 0.28 & 0.28 & 0.26 & 8 & 126 & 70 & 10 & 0 & 20 \\
\hline
\end{tabular}


Appendix B. Summary of dispersal distances from the literature of the different species of anurans in the study.

\begin{tabular}{|c|c|c|c|}
\hline Species & Location & $\begin{array}{l}\text { Mean distance in } \mathbf{m} \\
\text { (sample size) }\end{array}$ & Data source \\
\hline \multirow[t]{2}{*}{ American Toad } & Ontario & $138(69)$ & Oldham, $1966^{\mathrm{a}}$ \\
\hline & Newfoundland & $567(3)$ & Maunder, $1983^{b}$ \\
\hline \multirow[t]{3}{*}{ Green Frog } & New York & $263(13)$ & Lamoureux and Madison, $1999^{\circ}$ \\
\hline & Virginia & $722(65)$ & Schroeder, $1976^{\mathrm{a}}$ \\
\hline & Ontario & $137(109)$ & Oldham, $1967^{\mathrm{a}}$ \\
\hline \multirow[t]{2}{*}{ Western Chorus Frog } & Indiana & $116(47)$ & Kramer, $1973^{d}$ \\
\hline & Colorado & $105(125)$ & Spencer, $1964^{\mathrm{a}}$ \\
\hline \multirow[t]{3}{*}{ Wood Frog } & Virginia & $1169(66)$ & Berven and Grudzien, $1990^{\circ}$ \\
\hline & Newfoundland & $400(1)$ & Maunder, $1983^{\mathrm{b}}$ \\
\hline & Minnesota & $21(71)$ & Bellis, $1965^{\mathrm{a}}$ \\
\hline Gray Treefrog & Wisconsin & $40(33)$ & Roble, $1979^{\mathrm{a}}$ \\
\hline \multirow[t]{3}{*}{ Northern Leopard Frog } & Michigan & $815(971)$ & Dole, $1971^{\mathrm{a}}$ \\
\hline & Minnesota & $2414(2)$ & Merrell, $1970^{\mathrm{a}}$ \\
\hline & Alberta & $400(1)$ & Seburn et al., $1997^{\mathrm{a}}$ \\
\hline Spring Peeper & Michigan & $437(3)$ & Dezell, $1958^{\mathrm{a}}$ \\
\hline
\end{tabular}

${ }^{\mathrm{a}}$ Uniquely marked individuals.

${ }^{\mathrm{b}}$ Yearly rate of movement based on introduction.

${ }^{\mathrm{c}}$ Radiotransmitters.

${ }^{\mathrm{d}}$ Radioactive tags.

${ }^{\mathrm{e}}$ Genetics. 